\title{
Solar Technology Application To Enhanced Oil Recovery
}

Peter de Leon Kenneth C. Brown James W. Margolis Louise H. Nasr
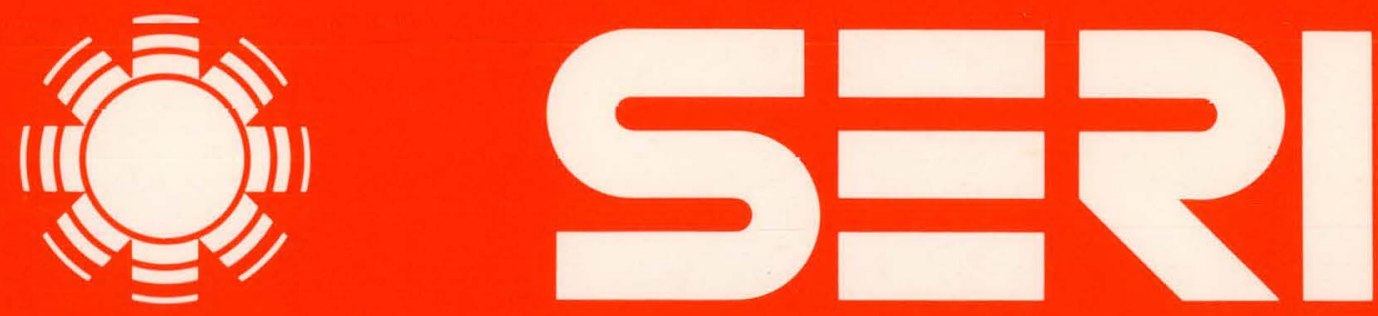

Solar Energy Research Institute A Division of Midwest Research Institute

1536 Cole Boulevard

Golden, Colorado 80401

Operated for the U.S. Department of Energy under Contract No. EG-77-C-01-4042

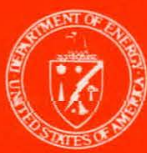




\section{DISCLAIMER}

This report was prepared as an account of work sponsored by an agency of the United States Government. Neither the United States Government nor any agency Thereof, nor any of their employees, makes any warranty, express or implied, or assumes any legal liability or responsibility for the accuracy, completeness, or usefulness of any information, apparatus, product, or process disclosed, or represents that its use would not infringe privately owned rights. Reference herein to any specific commercial product, process, or service by trade name, trademark, manufacturer, or otherwise does not necessarily constitute or imply its endorsement, recommendation, or favoring by the United States Government or any agency thereof. The views and opinions of authors expressed herein do not necessarily state or reflect those of the United States Government or any agency thereof. 


\section{DISCLAIMER}

Portions of this document may be illegible in electronic image products. Images are produced from the best available original document. 


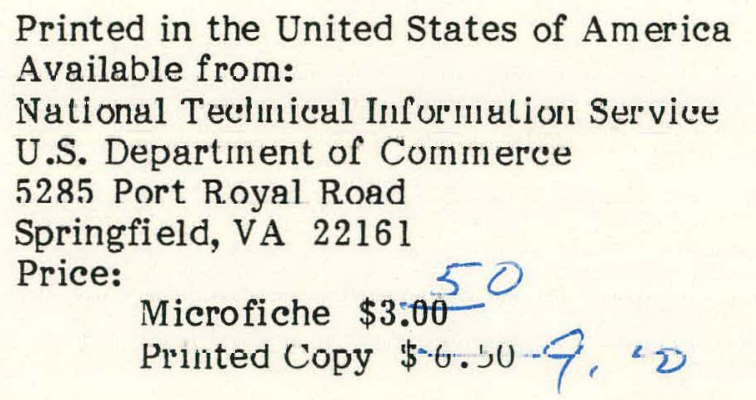

\section{NOTICE}

This report was prepared as an account of work sponsored by the United States Government. Neither the United States nor the United States Department of Energy, nor any of their employees, nor any of their contractors, subcontractors, or their employees, makes any warranty, express or implied, or assumes any legal liability or responsibility for the accuracy, completeness or usefulness of any information, apparatus, product or process disclosed, or represents that its use would not infringe privately owned rights. 
SER I /TR-352-392

UC CATEGORY: UC-59B

SOLAR TECHNOLOGY APPLICATION TC ENHANCED OIL RECOVERY

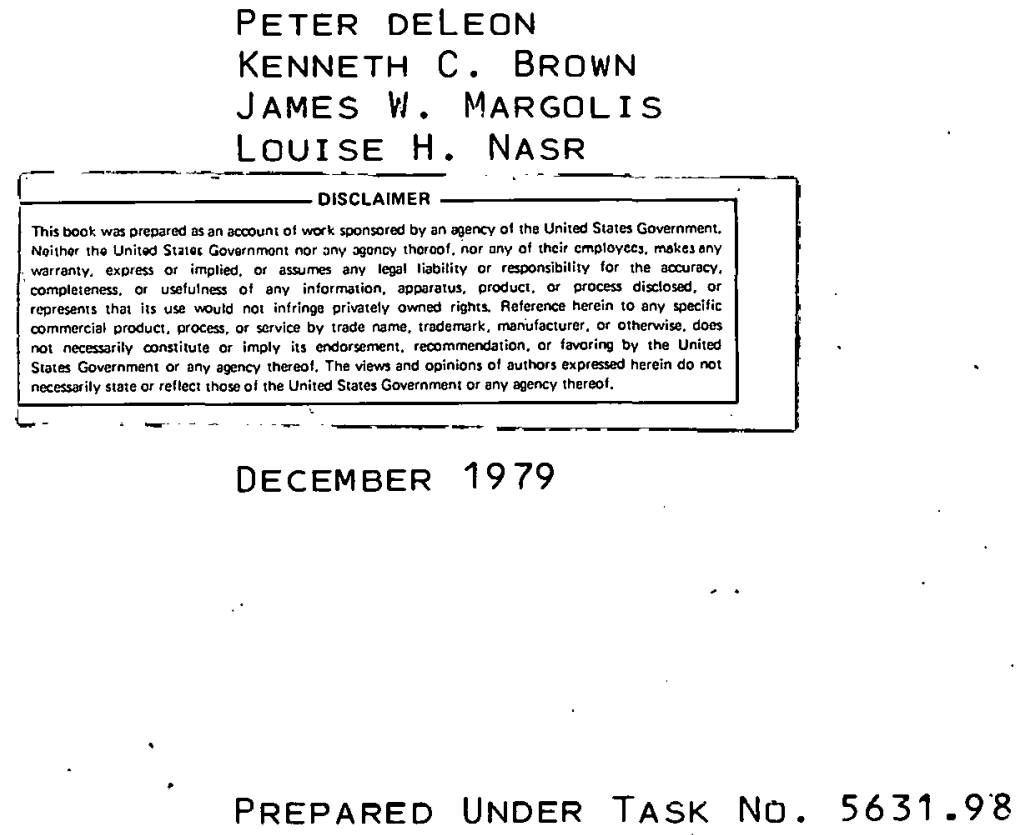

Solar Energy Research Institute

1536 Cole Boulevard

Golden, Colorado 80401

A Division of Midwest Research Institute

Prepared for the

U.S. Department of Energy

Contract No. EG.77.C.01.4042 
THIS PAGE

WAS INTENTIONALLY

LEFT BLANK 


\section{FOREWORD}

Results of the "Enhanced Oil Recovery" subtask of the "Institutional Responses to Solar Thermal Power Plants" task are presented in this report. This study analyzes the potential use of solar energy technologies in extracting petroleum from underground reservoirs by thermal enhanced oil recovery techniques. Specifically, it addresses the legal, environmental, and technical issues involved with solar technology applications to enhanced oil recovery. It also examines the expressed requirements of the petroleum industry.

As such, this report should be of particular interest to personnel in the U.S. Department of Energy and the petroleum industry, as well as those concerned with the commercial use of solar energy technologies.

Approved for:

SOLAR ENERGY RESEARCH INSTITUTE

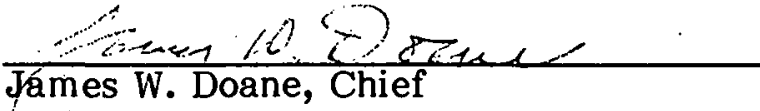

Policy Analysis Branch 


\section{ACKNOWLEDGEMENTS}

For this study of applying solar technology to enhanced oil recovery (EOR), the analysis extended well beyond the strict bounds of solar energy research. To appreciate the concerns of the petroleum industry, we interviewed a number of petroleum company officials. We are indebted to the insights they provided. We are particularly grateful to Professor Ching Wu of the Colorado School of Mines for his patience in explaining the mechanics and constraints involved in thermal EOR techniques. Kenneth C. Bergerson of the Sandia Laboratories, Albuquerque, generously shared his research methods and findings regarding line collector EOR systems. Personnel at the Energy Systems Division of the McDonnell-Douglas Corporation made their studies of central receivers available to us.

William Hochheiser of the Office of Planning and Technology Transfer, U.S. Department of Energy, was the study monitor; he consistently asked difficult questions which surely improved the quality of the analysis. Finally, Dennis Horgan, Elizabeth Perwin, Robert Copeland, and Joseph Finegold, all from SERI's Analysis Division, reviewed the draft version of the study; their comments were uniformly trenchant and greatly improved the report. 


\section{SUMMARY}

One means for the United States to increase its supply of domestic petroleum is to recover more of the oil lef $t$ in petroleum reservoirs after standard extraction techniques are no longer productive. Increasingly, American oil companies are using various enhanced oil recovery (EOR) techniques to this end. This report examines one EOR technique-thermal or steam enhanced oil recovery-and, in particular, the possible application of solar energy technologies to generate the steam used for thermal EOR.

Of the 373,000 barrels of oil per day extracted by EOR techniques in 1977, more than $70 \%$ was produced by thermal processes. Almost all of this was recovered in California because the physical characteristics of the California oil fields (e.g., porosity and depth) and the viscosity of the oil are especially conducive to steam EOR. Solar energy technologies are well suited for the production of steam. For this reason, the study focused on the requirements of California petroleum production; solar EOR systems applicable to these conditions were used.

Officials of the California petroleum production companies were interviewed to obtain an industry perspective on solar EOR. Most of the officials were interested in solar EOR systems but uninformed. The general consensus was that their companies were not presently interested because of the high initial costs, the unproven state of solar technology, and the yet undemonstrated mechanical reliability of the systems. Oil company representatives were unenthusiastic about cooperating with the government on demonstration programs; their clear preference for government participation would be through tax incentives, such as tax credits and accelerated depreciation. They pointed out that while they favored the deregulation of oil prices, decontrol would not necessarily benefit solar EOR. Decontrol would encourage all forms of EOR, not just those utilizing solar energy. If the federal government wants to encourage the commercialization of solar EOR, its best strategy would be to demonstrate the feasibility and reliability of the solar systems.

Environmental concerns are presently not a major motivation for the oil companies to favor solar EOR. Many more technically familiar, lower cost means for meeting air quality standards are available than the proposed solar EOR systems; unless severely constrained by environmental regulations, the oil companies prefer these methods. Finally, the oil companies generally finance their technology development projects from internal funding. In the case of solar EOR, however, the initial capital investment is so large that the willingness of the private sector to finance commercial solar EOR operations without federal tax incentives or loan guarantees is problematic.

Earlier EOR studies have raised four legal and environmental issues related to solar EOR: the surface rights of lessees under standard oil and gas leases; the unitization of oil fields; water supply and disposal; and air pollution. Although the first two issues could create some problem, current oil field operations suggest that the danger is more apparent than real. Neither surface rights nor unitization poses particular obstacles even though adjudication may be required in some instances. Regarding the availability of water necessary for steam production, current oil production indicates that there is ample water in the California oil fields if formation water is used. Likewise, water treatment and disposal do not seem to pose any technical or environmental problems at this time.

Many people have suggested that the nonpolluting character of solar energy EOR is a primary motivation underlying its possible adoption. For this reason, air quality 
regulations were examined closely to see how they might affect future conventional (oilfired) EOR steam generators, solar hybrid (a combination of solar and fossil-fueled), and pure solar EOR systems. The Getty Oil Company case, in which Getty was forced to curtail its thermal EOR operations because of a violation of sulfur dioxide air quality standards, is described. It suggests that air quality standards per se do not presently constrain the expansion of conventional-fired thermal EOR systems in California as long as the operator is willing to pay the high cost of complying with the various emission limitations. Burning permits are available, and solar EOR has not preempted the alternative, environmentally acceptable options. This statement explicitly assumes the continued availability of emission "offset" permits. However, in future years, it may become increasingly difficult to obtain new permits as the supply of emission offsets becomes restricted. Were this condition to occur, then air quality standards might yet force oil producers to adopt solar EOR or other nonpolluting systems to maintain production levels and air quality standards.

As noted, in designing and costing the solar energy EOR systems used in this analysis, the operational characteristics of the California oil fields (more specifically, those found in the Kern County region) were selected as representative. Steam requirements of $545^{\circ} \mathrm{F}$, 1000 psi, and $80 \%$ quality were chosen. A hybrid system (a combination solar and backup fossil-fired system to supply steam during nighttime hours or periods of low solar insolation) is the basis of the solar system design parameters; in other words, we assume 24-hr continuous injection of steam into the well as a necessary condition. The solar EOR system is designed to produce a peak daily output of $540 \mathrm{MBtu}$ for a day in June.

Six solar collector systems were considered initially with two-parabolic troughs and central receivers-examined more carefully. Each system was sized for two design scenarios, the advanced state of the art (system efficiencies and collector costs within 4-5 years) and system goals (system efficiencies and collector costs within the next 10-15 years). Based upon projected system efficiencies and the required system capacity, the initial capital costs and annualized costs for each of the four proposed solar systems were calculated. Similar costs were calculated for solar stand-alone systems (both with and without storage) and for fossil-fired thermal $\mathrm{EUK}$ systems. The annualized costs are summarized below in constant 1979 dollars per MBtu:

Solar: Parabolic Troughs

State of the Art

System Goals

Solar: Centrul Receiver

State of the Art

System Goals

Solar Stand-Alone Without Storage (State of the Art)

Parabolic Trough

$\$ 12.83$

Central Receiver

Solar Stand-Alone With Storage (State of the Art)

Parabolic Trough

$\$ 21.00$

Central Receiver

$\$ 14.74$ 
$\begin{array}{lr}\begin{array}{l}\text { Solar-Fossil Hybrid System } \\ \text { Parabolic Trough }\end{array} \\ \quad \text { State of the Art } & \$ 7.13 \\ \text { System Goals } & \$ 5.57 \\ \text { Central Receiver } & \\ \quad \text { State of the Art } & \$ 5.95 \\ \quad \text { System Goals } & \$ 5.05 \\ \text { Conventional Oil-Fired System } & \\ \text { Oil at } \$ 12.00 / \text { bbl } & \$ 4.80\end{array}$

Three findings need to be stressed here. First, central receivers have a clear cost advantage over parabolic troughs for solar EOR applications. This advantage is largely explained by the respective systems' net efficiencies and collector costs, variables which are subject to future uncertainty. Still, the cost differences between the two systems are significant and, if the existing uncertainties were resolved without a dominant bias for the parabolic troughs, it would be expected that the central receiver system would continue as the more cost-effective solar technology for EOR. A second finding is that solar EOR systems are cost comparable to oil-fired EOR systems but only in the goals stage of system development, i.e., 10-15 years in the future, again assuming that development goals are met. Finally, there are several important technical questions regarding the design and performance of solar EOR systems and the petroleum reservoir responses which require research before final system design estimates can be made.

A final area of analysis is the possible means of financing solar EOR projects. The standard method by which firms make investment decisions is based upon equity financing. Debt financing can lower the operating costs and provide a greater return on the investment but may expose the firm to magnified losses. It is difficult to evaluate a future project in terms of debt financing because the firm cannot be certain what financial conditions will prevail when it must make its investment decision.

Project financing is an alternative way of underwriting large capital investments in which the lender evaluates the loan based on the projected cash flow and treats the physical assets as collateral. Project financing has been proposed as a means of financing solar EOR projects. However, given the technological risk currently ascribed to solar technology, the questionable fungibility of the physical facility, and the problematic cash flow, project financing does not presently appear to be an attractive financing option for solar EOR. Leasing the equipment might be a more feasible option, especially in the face of an uncertain salvage value. However, financing by leasing is evaluated using the same criteria as purchase, but with the additional constraint of needing an assured customer for the equipment because the leasing company cannot use the equipment itself.

Eight major conclusions and recommendations may be drawn from this report. First, significant technical uncertainties surround the existing state of knowledge regarding both solar technologies and enhanced oil recovery; these must be resolved before any solar EOR concept will be commercially attractive. Pilot projects should be planned to address these uncertainties before moving into commercial-scale solar EOR applications.

Second, the analysis clearly shows that central receivers are better suited to EOR applications than distributed parabolic troughs, especially in the 10- to 15-year time frame. Therefore, central receivers should be given equal opportunity within the Department of Energy (DOE) for solar EOR development funding. 
Third, at the present time and for the near future, the application of solar technology to EOR is not cost effective. Specific technology development programs should be planned to drive down the cost of solar EOR systems rather than assuming that deregulation in the price of oil will be a sufficient stimulus.

Fourth, the market potential for solar EOR has not yet been determined. DOE might want to study the availability of land in California or the solar EOR potential in other geographic regions as first steps in estimating the potential market penetration capability of solar EOR systems.

Fifth, since project financing does not appear to be an attractive means of financing solar EOR investment, we recommend that government-guaranteed loans would be more useful in encouraging lending institutions to support solar EOR projects.

Sixth, although air quality standards are not presently a motivating factor uniquely favoring solar EOR, they could become a driving force in the future. Were this to occur, a solar hybrid EOR system might not be environmentally acceptable; therefore, we recommend that DOE initiate work on pure solar EOR systems (either with or without storage capabilities) that will not require emission of fsets.

Seventh, SERI interviews with petroleum officials revealed that they are seriously interested in solar EOR technology and costs but have little reliable information upon which to act. Most of their information came from solar manufacturers. Therefore, DOE could begin an on-going program to keep petroleum officials fully abreast of emerging technologies that might have applications to that industry.

Finally, even though there is a broad range of government incentives for promoting solar EOR, tax treatments are the most widely preferred by the potential consumer of EOR solar systems, the petroleum industry. If DOE wishes to encourage private industry participation in the development and use of solar EOR, a tax incentive program would probably be the most effective means and certainly the petroleum industry's favored option. If the solar EOR equipment is developed on schedule and performs as designed, a loan guarantee program would be the option of lowest cost to the government because there might easily be no cases of loan default. 


\section{TABLE OF CONTENTS}

$\underline{\text { Page }}$

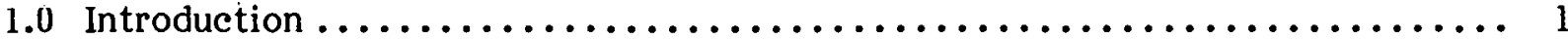

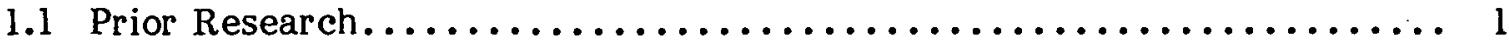

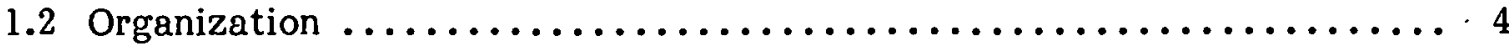

2.0 Enhanced Oil Recovery $\ldots \ldots \ldots \ldots \ldots \ldots \ldots \ldots \ldots \ldots \ldots \ldots \ldots \ldots \ldots \ldots \ldots \ldots$

2.1 Conventional Steam Supply System $\ldots \ldots \ldots \ldots \ldots \ldots \ldots \ldots \ldots \ldots \ldots \ldots$

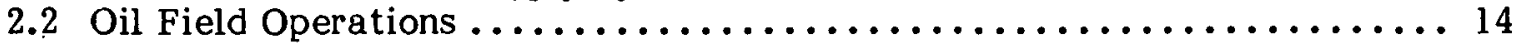

3.0 The Perspective of the Petroleum Industry $\ldots \ldots \ldots \ldots \ldots \ldots \ldots \ldots \ldots \ldots \ldots 17$

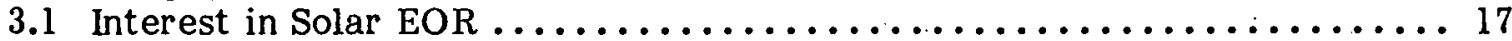

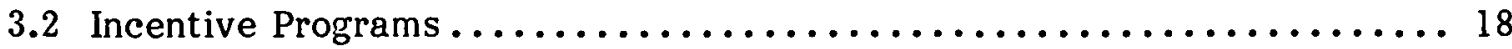

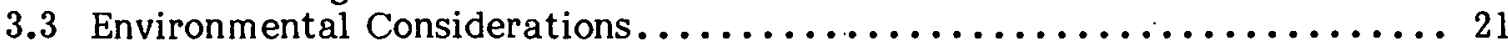

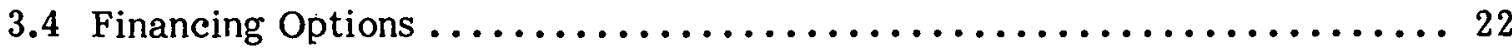

4.0 Legal and Environmental Issues Related to Solar EOR ................ 23

4.1 Surface Rights of Lessees under Oil and Gas Leases . . . . . . . . . . . 23

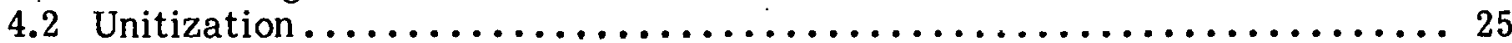

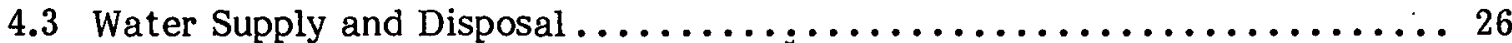

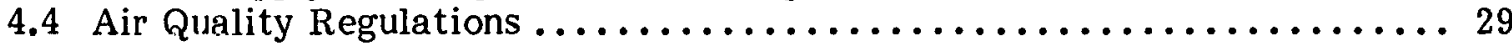

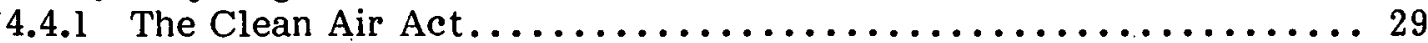

4.4.2 Ambient Air Quality Standards...................... 30

4.4.3 State Implementation Plans (SIP) and New Source

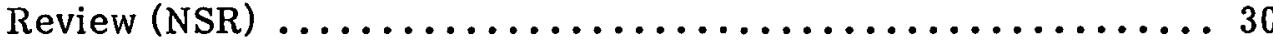

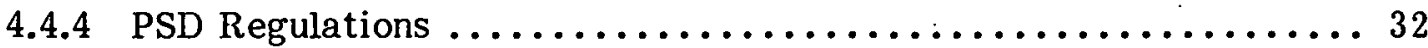

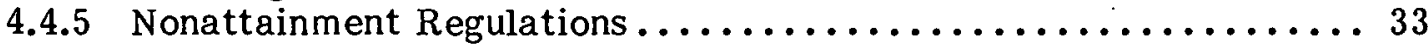

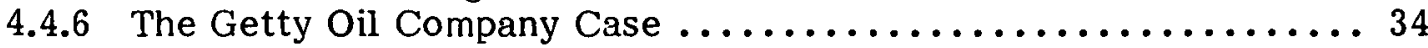

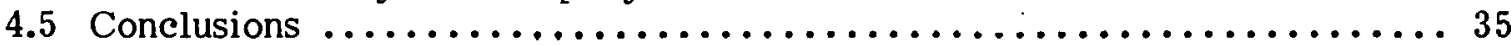

5.0 System Design Requirements $\ldots \ldots \ldots \ldots \ldots \ldots \ldots \ldots \ldots \ldots \ldots \ldots \ldots \ldots \ldots \ldots$

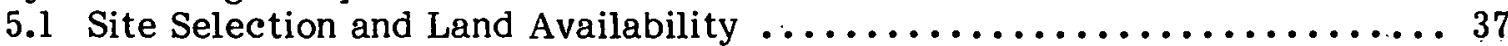

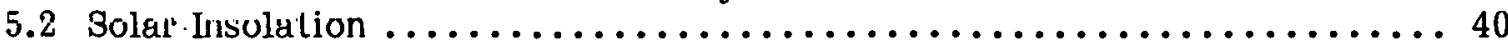

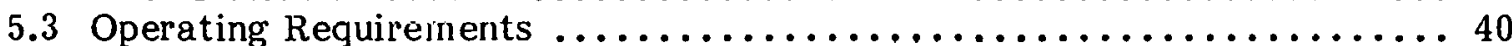

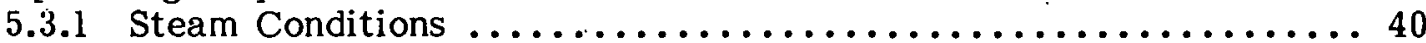

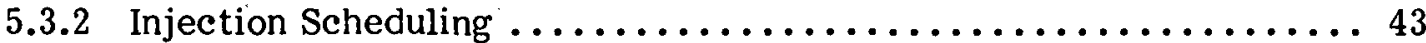

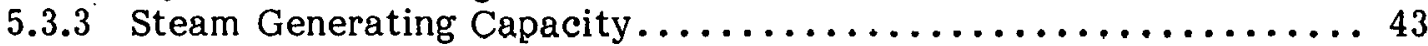

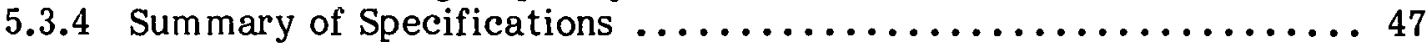

5.4 Review of Alternative Technologies $\ldots \ldots \ldots \ldots \ldots \ldots \ldots \ldots \ldots \ldots \ldots \ldots$

5.5 Physical and Economic Characteristics ................... 48

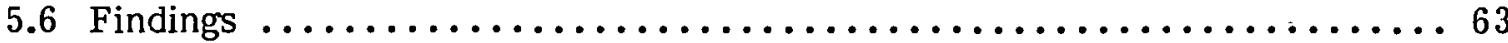

6.0 Financing Solar Enhanced Oil Recovery $\ldots \ldots \ldots \ldots \ldots \ldots \ldots \ldots \ldots \ldots \ldots \ldots$

6.1 Investment Decisions and Project Economics ................. 67

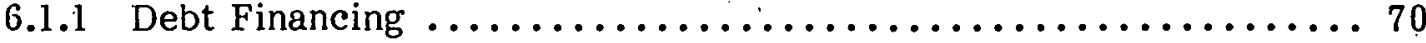

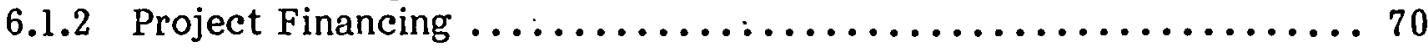

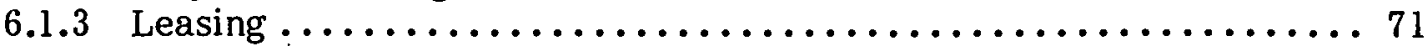

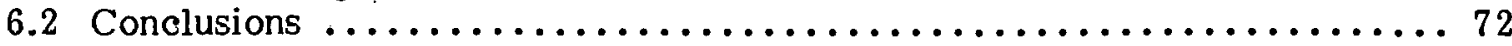




\section{TABLE OF CONTENTS (concluded)}

7.0 Conclusions and Recommendations $\ldots \ldots \ldots \ldots \ldots \ldots \ldots \ldots \ldots \ldots \ldots \ldots \ldots$

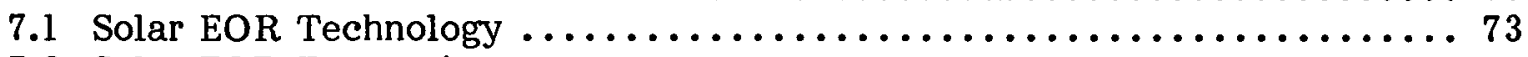

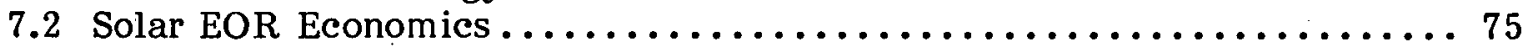

7.3 Legal and Institutional Issues Regarding Solar EOR . . . . . . . . 76

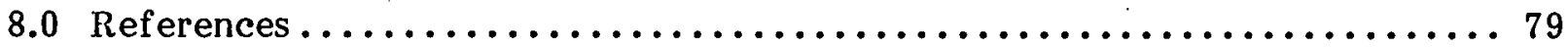

Appendix A. Ambient Air Quality Standards .......................

Appendix B. Potential $\mathrm{SO}_{2}$ Emissions from a $50-\mathrm{Million} \mathrm{Btu} / \mathrm{hr}$ Oil Boiler .................................. 


\section{LIST OF FIGURES}

Figure $\quad$ Page

2-1 Location of Steam EOR Projects in the United States $\ldots \ldots \ldots \ldots \ldots \ldots$

2-2 Schematic Illustration of Steam Drive Displacement Mechanism

in Oil Reservoirs ................................ 9

2-3 Injection/Producing Well Placement Patterns $\ldots \ldots \ldots \ldots \ldots \ldots \ldots \ldots \ldots$

2-4 Typical Steam Generators, $\operatorname{Kern}$ County $\ldots \ldots \ldots \ldots \ldots \ldots \ldots \ldots \ldots \ldots$

2-5 Oil Field $\mathrm{SO}_{2}$ Scrubber Installation $\ldots \ldots \ldots \ldots \ldots \ldots \ldots \ldots \ldots \ldots \ldots \ldots$

4-1 San Joaquin Valley Air Basin $\ldots \ldots \ldots \ldots \ldots \ldots \ldots \ldots \ldots \ldots \ldots \ldots \ldots \ldots$

5-1 Bakersfield, California, and Nearby Oil Fields ................ 38

$5-2$ Typical Terrain of California Oil Fields Country ................ 39

5-3 Location of Meteorological Stations Near Bakersfield, California..................................... 41

5-4 Daily Load and Solar Steam Supply Profiles for Solar Stand-Alone Systems ............................ 44

5-5 Daily Load and Solar System Supply Profiles for Hybrid Systems ............................... 46

5-6 Daily Load and Solar Steam Supply Profiles for Solar Systems with External Storage ............................ 46

5-7 Monthly Energy Delivery from Solar Hybrid EOR Systems (A and C)

5-8 Annual Capacity Factor vs. Storage Size for Several Collector Areas. 
THIS PAGE

WAS INTENTIONALLY

LEFT BLANK 


\section{LIST OF TABLES}

Table

$\underline{\text { Page }}$

1-1 Estimates of Enhanced Oil Recovery Potential $\ldots \ldots \ldots \ldots \ldots \ldots \ldots \ldots \ldots$

2-1 Well and Reservoir Properties for Oil Fields Using Steam EOR in

Central California ............................... 8

2-2 Conventional Steam Generator Costs $\ldots \ldots \ldots \ldots \ldots \ldots \ldots \ldots \ldots \ldots \ldots$

3-1 Surveyed Petroleum Companies $\ldots \ldots \ldots \ldots \ldots \ldots \ldots \ldots \ldots \ldots \ldots \ldots \ldots \ldots$

4-1 Estimated Percentage Ownership of Heavy Oil Fields in

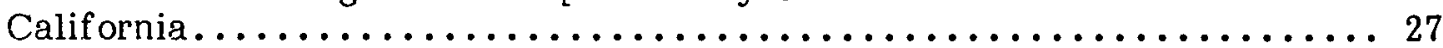

4-2 Water Balance for the 11 Largest Thermal Oil Fields in

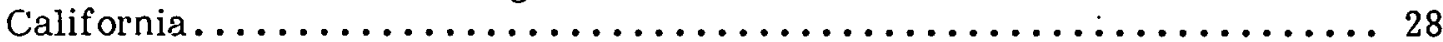

4-3 Attainmont Status of Kern County Portion of San Joaquin Valley

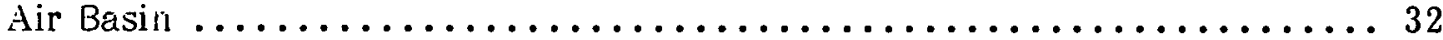

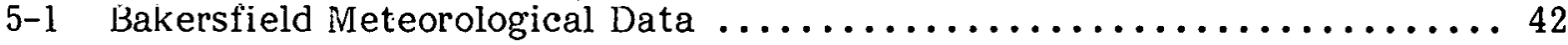

5-2 Six Generic Solar Thermal Systems for Enhanced Oil Recovery . . . . . . . 49

5-3 Comparison of Generic Solar EOR Systems $\ldots \ldots \ldots \ldots \ldots \ldots \ldots \ldots \ldots \ldots$

5-4 Specifications for Solar Components ...................... 51

5-5 Performance and Physical Characteristics of Solar EOR Systems ....... 52

5-6 Comparative System Capital Costs ...................... 55

5-7 Average Annual Operating Costs $\ldots \ldots \ldots \ldots \ldots \ldots \ldots \ldots \ldots \ldots \ldots \ldots \ldots$

$5-8 \quad$ Levelized Energy Costs $\ldots \ldots \ldots \ldots \ldots \ldots \ldots \ldots \ldots \ldots \ldots \ldots \ldots \ldots \ldots$

5-9 Stand-Alone Solar EOR System ........................ 60

5-10 Stand-Alone Solar EOR System with Storagc $\ldots \ldots \ldots \ldots \ldots \ldots \ldots \ldots \ldots \ldots$

5-11 Comparison of Solar Thermal EOR Systems ( $A$ and C) for Fixed

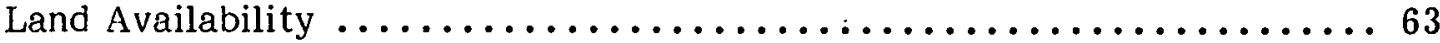

5-12 Conventional Thermal EOR Costs $\ldots \ldots \ldots \ldots \ldots \ldots \ldots \ldots \ldots \ldots \ldots \ldots$

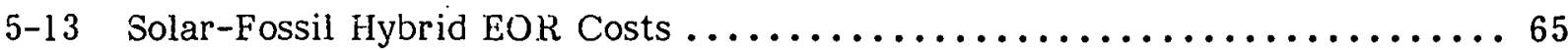

6-1 Financial Returns under Varying Debt/Equity Ratios ..............68

6-2 Solar EOR Systems: Equity vs. Debt Financing $\ldots \ldots \ldots \ldots \ldots \ldots \ldots \ldots \ldots$ 


\section{SECTION 1.0}

\section{INTRODUCTION}

Faced with limited domestic reserves of petroleum and increased dependence on foreign petroleum supplies to meet present and projected energy demands, government and private energy analysts have been exploring new sources of petroleum or petroleum substitutes. This search has been accelerated by the potential dangers of a reliance on Middle East and African petroleum suppliers (deLeon and McNown 1979). One manifestation of this concern has been the current Congressional and Administration efforts to develop synthetic fuels, or "synfuels," to a production level of 1.5 million barrels a day (bbl/day) by 1990 . The second option that has received Administration emphasis is the increased production of heavy petroleum; i.e., petroleum with an API gravity of $16^{\circ}$ or less, which indicates a relatively high viscosity or density (Parisi 1979; Anonymous 1979a; Solomon 1979).*

Two ways to increase present oil supply levels would be for the federal government to encourage new exploration for yet-untapped oil reservoirs or to increase the amount of oil that can be extracted from existing fields. Given the increasingly high risks ascribed to oil exploration and drilling and the fact that present extraction techniques leave close to two-thirds of the known oil reservoirs under ground, the second option is gaining increased attention. To this end, the U.S. Department of Energy (DOE) and oil companies have begun to emphasize methods for extracting greater amounts of oil from known reservoirs by using "tertiary," or "enhanced," oil recovery (EOR) techniques. Subsuming a number of different techniques, EOR has been described in the popular press (Sheils 1979) and suggested as an alternative to increased synfuel production.**

This report considers one kind of enhanced oil recovery-the so-called "thermal" processes-and, within the thermal processes, the capability of solar energy technologies to meet the technical requirements for thermal enhanced oil recovery. $\|$

\subsection{PRIOR RESEARCH}

Enhanced oil recovery is hardly a novel approach to augment petroleum production. -The advantages of injecting steam into oil wells to increase their productivity were first suggested in 1917 (Ali 1974). - Large-scale field tests for steam injection were begun in the late 1950s and gained some attention in the early 1960s "following the Shell Oil Company's success with cyclic steam stimulation in California" (Ali 1974). California oil fields, where the reservoir and petroleum characteristics particularly favor steam

*Furthermore, President Carter has proposed that heavy crude be exempted from the windfalls profits tax. Controversy exists over the appropriate definition of heavy crude, with some producers claiming that the cutoff point should be at least $20^{\circ}$ API gravity rather than $16^{\circ}$; see Wilson (1979).

**Frank Zarb, the former Director of the Federal Energy Administration, made this suggestion before the Senate Energy Committee (Maize 1979).

ISection 2.0 presents the definitions and technical requirements that characterize oil fields and enhanced oil recovery. 
injection EOR techniques, have had the most experience with thermal EOR; by 1971, close to $53 \%$ of the California oil wells had been steamed at least once (Office of Technology Assessment 1978, p. 158). In 1978, the Oil and Gas Journal estimated that approximately $373,000 \mathrm{bbl} /$ day of oil were produced in the United States by tertiary production methods; of this total, $250,000 \mathrm{bbl} /$ day (or two-thirds) were steam generated (Noran 1978).

If a consensus exists on the general efficacy of thermal EOR techniques, there is much less agreement on the magnitude of the potential returns that can be obtained by EOR methods. Based on a projected 300 billion barrels of oil that will remain in known reservoirs after the conventional primary and secondary production methods have been employed,* estimates on the cumulative amount of oil that might be recovered by EOR techniques range from 7 billion barrels to 76 billion barrels. The projections of several widely circulated EOR studies are provided in 'l'able 1-1. The wide variance in estlmates reflects significant technical uncertainties in EOR technologies, government policy toward EOR, government policy in general, and, most critically, the price which petroleum producers can obtain for their product (Anonymous 1978b).

This report differs from other EOR studies in that it focuses almost exclusively on solar technology applications to thermal EOR. It does not compare efficiencies of the different types of EOR techniques, nor does it address the isside of how many barrels of oil might be recovered by using solar EOR techniques.** This report emphasizes the comparison among different solar energy technologies, asking which are the most feasible from cost, technology, and availability perspectives. The underlying assumption-that EOR can contribute in large measure to meeting the national demand for petroleum-is based primarily on analyses presented elsewhere regarding the number of barrels of oil that EOR could significantly add to U.S. accessible oil reserves over the total currently projected (at a given price level). $I$

'The analysis of solar technology applications of EOR rests on the assumption that the energy from the sun can be collected and focused to generate steam. The remainder of the process - the injection of steam into an ofl reservolr to slimulale petruleun production-parallels traditional thermal EOR operations. While it is technically possible for solar technologies to produce high quality steam that can be injected underground, disagreement exists on which technological designs are best suited for solar applications to EOR and on how these solar applications compare with more conventional EOR techniques from the economic, environmental, and institutional perspectlves.

*The different technical definitions and explanations relating to EUK are addressed in Section 2.0.

**Other reports cover these topics quite thoroughly: Office of Technology Assessment (1978), National Petroleum Council (1976), Mathematica Inc. (1975), Gulf Universities Research Consortium (1973), Lewin and Associates (1976b), and Lewin and Associates (1976c).

INot all studies find that EOR will make significant contributions to the national energy requirements; see Stobaugh and Yergin (1979, p. 43). 
Table 1-1. ESTIMATES OF ENHANCED OIL RECOVERY POTENTIAL

\begin{tabular}{|c|c|}
\hline Source & $\begin{array}{l}\text { Potential EOR Recovery } \\
\text { (billions of barrels) }\end{array}$ \\
\hline $\begin{array}{c}\text { OTA Report }{ }^{2}(1976 \$) \\
\$ 11.62 / \mathrm{bbl} \\
\$ 13.75 / \mathrm{bbl} \\
\$ 22.00 / \mathrm{bbl}\end{array}$ & $\begin{array}{l}21.2 \\
29.4 \\
41.6\end{array}$ \\
\hline $\begin{array}{c}\text { NPC Study }{ }^{b}(1976 \$) \\
\$ 5 / b b l \\
\$ 10 / b b l \\
\$ 15 / b b l \\
\$ 20 / b b l \\
\$ 25 / \mathrm{bbl}\end{array}$ & $\begin{array}{r}2.2 \\
7.2 \\
13.2 \\
20.5 \\
24.0\end{array}$ \\
\hline $\begin{array}{c}\text { GURC }^{\mathrm{C}}(1974 \$) \\
\$ 10 / \mathrm{bbl} \\
\$ 15 / \mathrm{bbl}\end{array}$ & $\begin{array}{l}18-36 \\
51-76\end{array}$ \\
\hline $\begin{array}{c}\text { Mathematicad }(1975 \$) \\
\$ 1-12 / \mathrm{bbl} \\
\$ 12-16 / \mathrm{bbl}\end{array}$ & $\begin{array}{r}7 \\
16\end{array}$ \\
\hline $\begin{array}{c}\text { Lewin \& Associates }{ }^{\mathrm{e}}(1975 \$) \\
\$ 11.28 / \mathrm{bbl}\end{array}$ & $15.6-30.5$ \\
\hline $\begin{array}{l}\text { a office of Technology Assessment (1978). } \\
b_{\text {National Petroleum Council (1976). }} \\
{ }^{c} \text { Gulf Universities Research Consortium (1976). } \\
d_{\text {Mathematica, Inc. (1975). }}\end{array}$ & . \\
\hline
\end{tabular}

To the best of our knowledge, this particular aspect of enhanced oil recovery has not been examined. Basic resource books on the thermal EOR processes do not consider the possibility of solar energy being used to generate steam (Interstate Oil Compact Commission 1974; Schumacher 1978; Ali.1970), nor have analyses of solar energy applications addressed this particular application.* One partial exception is Noran's 1978 review of EOR, in which he states, "One set of calculations generated from data .... shows

*For example, the solar energy task force report for Project Independence-a study specifically commissioned to develop American independence from foreign oil sourcesmakes no mention of solar technology applications to EOR (National Science Foundation 1974); also, the Office of Technology Assessment (1978) study of solar technologies makes no mention of solar EOR possibilities. 
solar steam generation could cost as much as $\$ 3,000 / b / d$ of production" (Noran 1978 , p. 118).*

If technically and economically feasible, EOR would seem particularly attractive from the standpoint of energy acquisition costs or energy accounting because it would not utilize finite (nonrenewable) energy resources to generate the steam used to increase oil production.** Solar enhanced oil recovery offers the potential ability of solar technologies to increase the domestic production of heavy petroleum without depleting existing natural resources.

For these reasons, the Office of Planning and Technology Transfer in DOE's Energy Technology Division asked the Solar Energy Research Institute to examine the comparative costs and benefits of different solar technologies applied to enhanced oil recovery. This report documents that analysis.

\subsection{ORGANIZATION}

The report is organized in six major sections in addition to the Introduction. Section 2.0 is a general discussion of enhanced oil recovery techniques. It also considers the petroleum reservoir characteristics that dictate EOR operational requirements. The third section investigates the institutional and operational considerations of the petroleum companies who are the potential purchasers and operators of solar EOR technologies; that is, it examines the industry demand for solar EOR. Section 4.0 analyzes the legal and environmental issues posed by the OTA and National Petroleum Council reports on EOR as being potentially restrictive to tertiary recovery operations. Section 5.0, which composes the main body of the report, offers technical and cost comparisons of solar technologies applied to EOR, while Section 6.0 looks at alternative means of financing these systems. Section 7.0 summarizes the findings of the report and presents policy rccommendations.

*The estimate is not explained.

**See the papers assembled by the Congressional Research Service for the U.S. House of Representatives Subcommittee on Energy Research, Development, and Demonstration (1976). 
SECTION 2.0

\section{ENHANCED OIL RECOVERY}

Crude oil is found in rock formations, called reservoirs, at depths ranging from $100 \mathrm{ft}$ to more than $17,000 \mathrm{ft}$ beneath the earth's surface. The oil mingles in pore spaces with water and, occasionally, gas. The size, shape, and degree of interconnection of the pores vary considerably from reservoir to reservoir and even within a reservoir. Oil reservoirs are described by several characteristics, such as oil viscosity, depth, zone thickness, shape of the underground formation, and pore permeability, which together determine the amount of oil that can ultimately be removed.*

The initial stage in extracting oil from a reservoir is termed primary production. The petroleum is forced to the surface by natural forces, such as gas, the natural expansion pressures of oil, naturally pressurized water, or drainage downward from a higher elevation. Depending on the field characteristics, the amount of oil recovered through primary production means can range from $10-50 \%$ of the oil in place, but the average is usually less than $30 \%$ (Schumacher 1978, p. 18).

To extract additional petroleum, secondary oil recovery technigues are employed, which in the United States has generally meant the injection of water into the well to reestablish natural pressures (hence, the generic term, "pressure maintenance"). By 1973, about one-half of the U.S. domestic oil production came from fields that had been partly or completely waterflooded (Craig 1978). "Cumulative recoveries by primary and secondary production, where the secondary production is waterflooding, average $38-43 \%$ of the original oil in place" (Office of Technology Assessment 1978, p. 26), although the range is as low as $5 \%$ and as high as $80 \%$. "This broad range of recovery efficiency is a result of the variations in the properties of the specific rock and fluids involved from reservoir to reservoir, as well as the kind and level of energy that drives the oil to the producing wells, where it is captured" (National Petroleum Council 1976, p. 12).

The same variables determine what methods of tertiary (enhanced) oil recovery are best suited to extract additional amounts of petroleum from the reservoirs. The capillary action of the pores upon the oil, the oil's viscosity, and simple gravity all act to impede the further extrartion of oil by conventional primary and secondary recovery methods. Therefore, oil producers have turned to enhanced-some call them "exotic"-recovery techniques to reduce the capillary forces by dissolving the trapped oil or by reducing its viscosity so that it flows more readily.

In general terms, tertiary oil recovery methods can be grouped into three types: (1) thermal processes, including in situ combustion; (2) carbon dioxide or gas miscible processes; and (3) chemical processes, including surfactant/polymer flooding, polymer flooding, and alkaline flooding.** The most recent statistics on oil produced in the

* Several of the critical reservoir characteristics are listed by the National Petroleum Council (1976, p. 24).

**These techniques are reviewed in detall by, inter alia, Interstate Oil Compact Commission (1974), Office of Technology Assessment (1978, Appendix B); Lewin and Associates (1976a), National Petroleum Council (1976, Appendices D-F), and Schumacher (1978). 
United States by enhanced recovery techniques highlight the current dominance of the thermal processes. Of the 373,000 bbl/day extracted by EOR techniques, $70 \%$ is attributed to thermal processes, compared to $29 \%$ and less than $1 \%$ for the gas miscible and chemical processes, respectively (Noran 1978). Most of the thermal EOR is performed in the California oil fields (see Fig. 2-1) because of their petroleuin and reservoir characteristics. The range of well and reservoir properties in California oil fields using thermal EOR is shown in Table 2-1.

As noted in the Introduction, this report is concerned primarily with solar technology applications to EOR. Because of the heat-generating properties of solar technologies, this study concerns itself only with the thermal EOR techniques, of which there are two broad categories: hot fluid injection and in situ combustion. In situ combustion, in which the producer actually ignites part of the underground reservoir and uses steam to drive the remaining oil toward a producing well, does not lend itself to the properties offar $\theta$ d by solar technologies and, therefore, is not discussed here. Hot fluid injection techniques include both hot waterflooding and steam stimulation. The techniques are similar in that heat is carried to the oil reservoir via an extornally (surfare) heater transfer medium. Hot waterflooding is not as widely used as steam stimulation because it is not as efficient. Therefore, this report addresses only solar applications to steam stimulation techniques.

Basically, steam stimulation enhanced oil recovery heats the oil reservoir, thereby reducing the oil's viscosity, inducing a greater oil flow, and thus increasing oil production. Any means of heating water may be used to generate the steam that is injected underground. Gas, coal, electric power, and solar energy have all been proposed or used, but the most often employed source of energy is petroleum from the reservoir itself.* The industry's rule-of-thumb is that one barrel of crude is burned to fuel the steam generators to extract three barrels of oil.

Two types of steam stimulation commonly are found in Amcrican oil fields: cyclic steam injection and continuous steam injection. Cyclic steam injection, also referted to as "huff and puff," involves the injection of slcun into a reservoir for a time period of one. week to a month. The injections are then stopped, the wells closed down, and the reservoir allowed to "soak" (hence, cyclic steam injection is also called "steam soaking"), af ter which the producing wells are reopened and the combination of heat and increased reservoir pressure allow more oil to be extracted. The cycle is repeated until the oil in the immediate area has been removed. Repeated eycles are increasingly ineffoctive and uneronomic, resulting, in final recovery of no more than 10-15\% of net oil in place (Ali 1974, p. 163).

Continous steam injection, also known as steamdrive or steamflooding, involves the continuous injection of steam into the rescrvoir and continuous extraction from the production wells. Steam is injected in a way that lowers the viscosity of the oil while driving it toward the production well. The combination of these effects accounts for the greater effectiveness of continuous steam injection in recovering oil; oil recovery efficiencies for steamflooding range from 35-50\% of the oil in place (Schumacher 1978, p. 72).

*Petroleum engineers in the USSR have proposed thermal methods utilizing underground nuclear explosive (Schumacher 1978, pp. 82-85). 


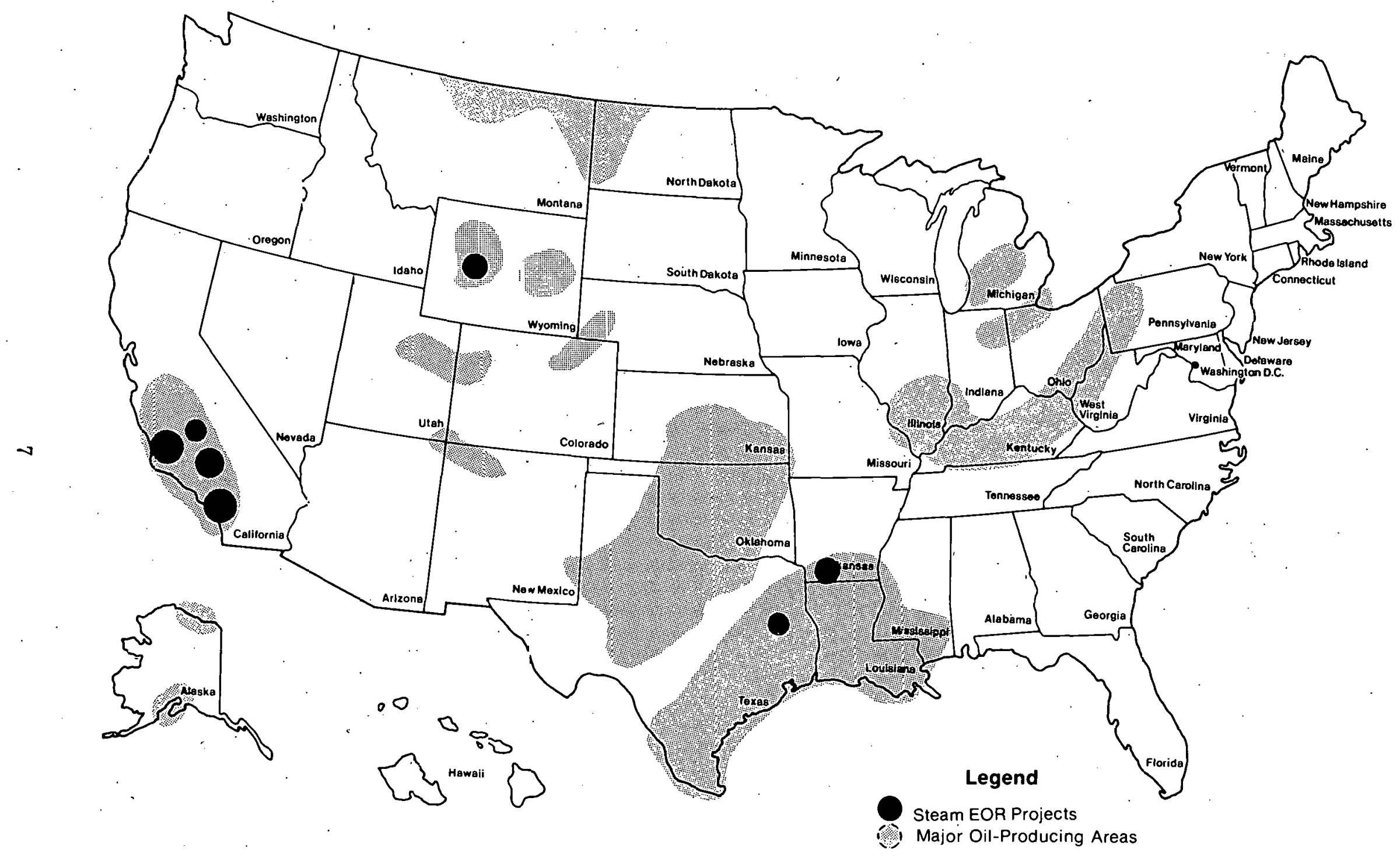

Figure 2-1. Location of Steam EOR Projects in the United States 
Table 2-1. WELL AND RESERVOIR PROPERTIES FOR OIL FIELDS USING STEAM EOR IN CENTRAL CALIFORNIA

\begin{tabular}{|c|c|c|c|c|c|c|}
\hline & \multicolumn{3}{|c|}{ Steam Soak (Cyclic) } & \multicolumn{3}{|c|}{ Steam Drive (Continuous) } \\
\hline & Min. & Typical & $\operatorname{Max}$ & Min. & Typical & Max. \\
\hline Project Area (acres) & 10 & 700 & 6,700 & 5 & 100 & 5,000 \\
\hline Well Depth (feet) & 200 & 1,000 & 2,800 & 400 & 1,500 & 2,800 \\
\hline Porosity (\%) & 27 & 32 & 41 & 25 & 33 & 39 \\
\hline Permeability (millidarcies) & 400 & 2,000 & 6,000 & 400 & 2,000 & 20,000 \\
\hline Oil Gravity ( $\mathrm{API})$ & 10 & 13 & 18 & 10 & 12 & 20 \\
\hline \multicolumn{7}{|l|}{ Initial Resldual } \\
\hline Saturation (\%) & 60 & 90 & 100 & 55 & 85 & 100 \\
\hline \multicolumn{7}{|l|}{ Estimated Final } \\
\hline Residual Saturation (\%) & 40 & 80 & 94 & 25 & 60 & 70 \\
\hline
\end{tabular}

Source: Anonymous (1977).

Figure 2-2 schematically shows how continuous injection displaces oil toward producing wells. Steamflooding projects are placed in a regular pattern throughout the oil field. The most common pattern places one injection well among four producing wells (the socalled inverted five-spot) although patterns with one injection well among every seven or nine producing wells also have been used to obtain higher extraction rates (see Fig. 2-3). Note that an inverted five-spot spacing in a continuous pattern actuilly provides a oneto-one ratio of injection wells to producing wells.

\subsection{CONVENTIONAL STEAM SUPPLY SYSTEMS}

Steam normally is supplied to injection wells by the kind of steam generators shown in Fig. 2-4. Typically, these generators have a 50-MBtu/hr capacity, but they also are manufactured in sizes as small as $10 \mathrm{MBtu} / \mathrm{hr}$. They usually are fired by crude petroleum extracted from the field. Except in the cases of small operator's, several steam generators are clustered together in a field to provide steam to many injection wells. Clustering is preferred as a means of decreasing construction costs, lowering operation and maintenance costs, and lessening interference with drilling leaseliolds. In addition, the manifolding of exhaust stacks (as shown in Fig. 2-5) allows the purchase and installation of a single, large sulfur dioxide ( $\mathrm{SO}_{2}$ ) scrubber for several generators if required by environmental regulations (seo Seo. 4.0 ).

Feedwater is supplied to storage tanks from a wastewater treatment facility. Wastewater treatment is necessary because of the considerable amount of formation water (upwards of $85 \%$ by volume) that is mixed with crude oil as it is pumped from the reservoir. The temperaturc of the feedwater to the steam generator is normally about $120^{\circ} \mathrm{F}$ to $140^{\circ} \mathrm{F}$ due to the various water treatment processes required af ter the oil is extracted from the reservoir. In at least one instance, producers have found it cost-effective to 

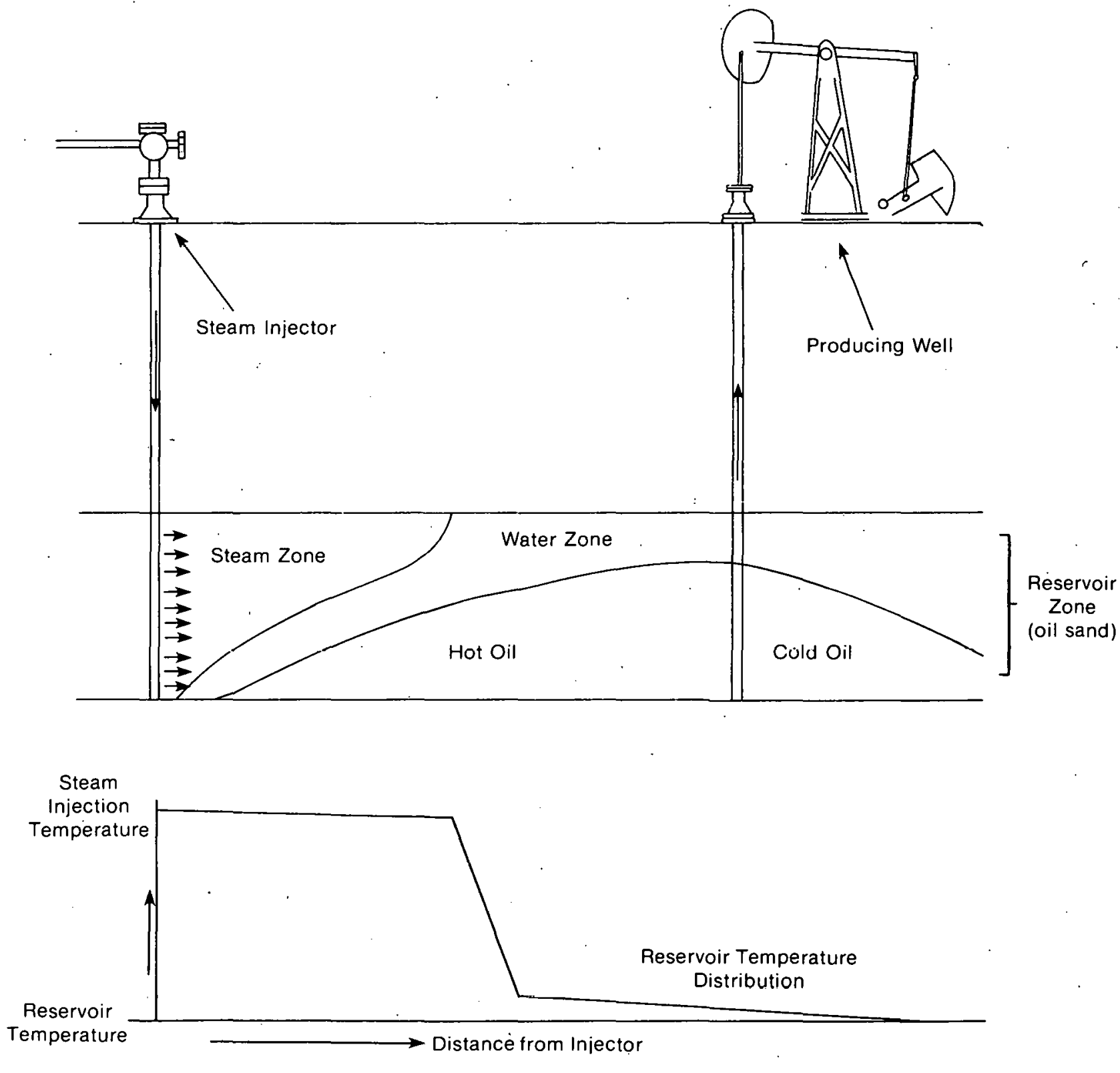

Figure 2-2. Schematic Illustration of Steam Drive Displacement Mechanism in Oil Reservoirs (Oil and Gas Journal 1965) 


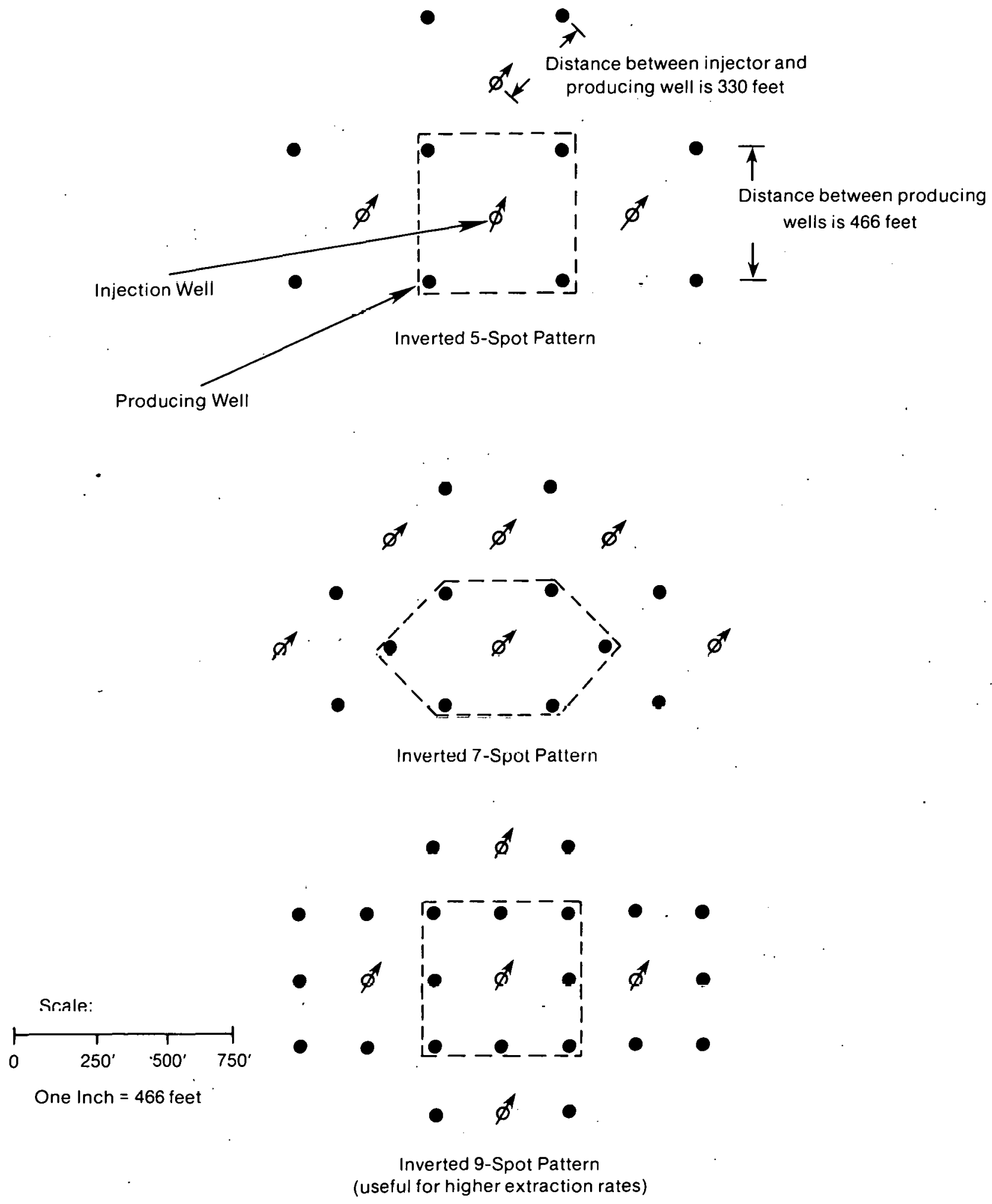

Figure 2-3. Injection/Producing Well Placement Pattern (5 acre spacing assumed) 

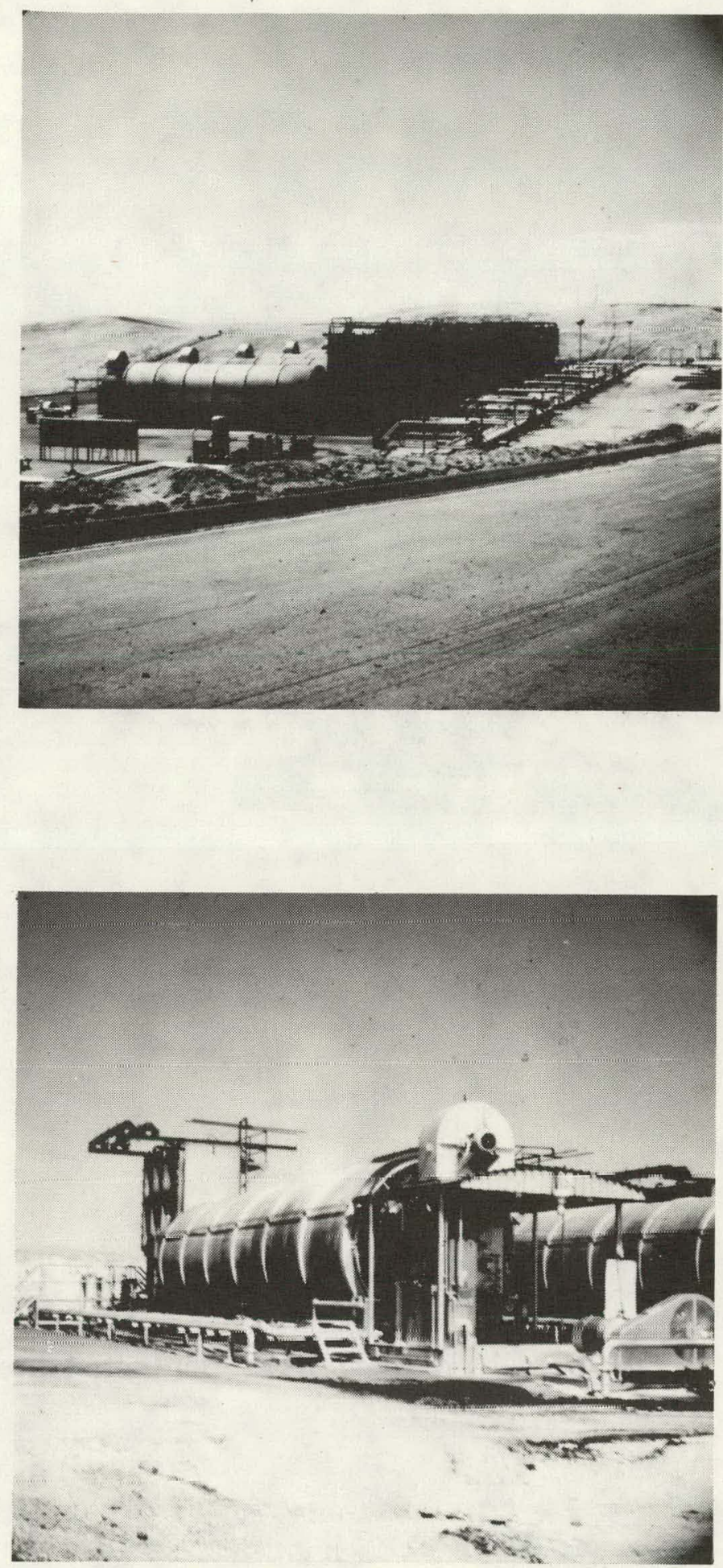

Figure 2-4. Typical Steam Generators, Kern County 


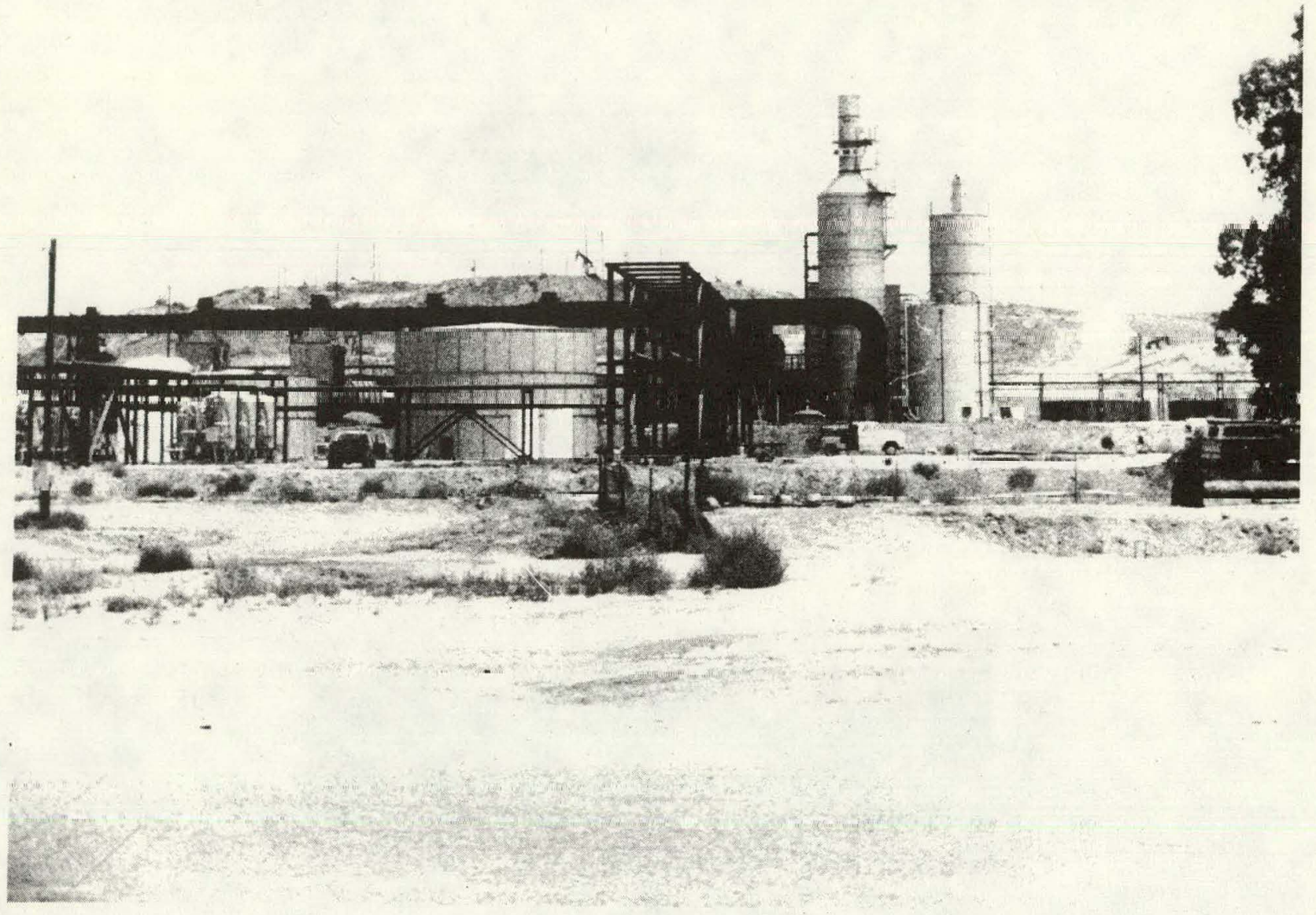

Figure 2-5. Oil Field $\mathrm{SO}_{2}$ Scrubber Installation 
insulate feedwater lines from the waste treatment facility.* Water for steam generators is stored in tanks near the generator cluster.

Most steam generators used for thermal EOR are of the once-through, water-tube type and are suitable for generating saturated steam up to 1,000 psi, although rated pressure capacities of 1,500 psi to 2,500 psi are not uncommon. These generators may be fired with lease crude, propane, natural gas, or fuel oil. Generating steam at less than $100 \%$ quality (usually $80 \%$ ) minimizes the deposit of solids in the water tubes. Some field operators have expressed concern over the thermal effects of rapid cycling of steam generators. Not only might such cycling introduce thermal stress and/or fatigue in refractory elements, but generator efficiency at partial load may be reduced by as much as $50 \%$. Normal operating efficiencies for steam generators are about $83 \%$. Boiler operation should be maintained as close to rated. capacity as possible to maximize boiler efficiency (Ali 1974, p. 172). However, as a means of extending operating life, boilers normally are fired at only about $90 \%$ of rated capacity (i.e., $45 \mathrm{MBtu} / \mathrm{hr}$ for a $50-\mathrm{MBtu} / \mathrm{hr}$ boiler).

Steam generators are manufactured and installed by a number of firms, including Combustion Engineering-NATCO, Struther-Wells, Hopper, Inc., Halliburton, and Thermotics. Cost of the installed steam generator $\left(50 \mathrm{MBtu} / \mathrm{hr}\right.$ ) with $\mathrm{SO}_{2}$ scrubbers is on the order of one million dollars. Annual operating costs for a $50-\mathrm{MBtu} / \mathrm{hr}$ generator, including fuel costs (at $\$ 12 / \mathrm{bbl}$ ) at $90 \%$ capacity, 350 days per year, are approximately $\$ 1.4$ million; this assumes that four barrels of steam are injected for every one barrel of oil recovered. For comparison, the capital and operating costs of coal-fired, gas-fired, and electric boilers of 50-MBtu/hr capacity are shown in Table 2-2. Recently, Pacific Gas and Electric Company submitted a proposal to the California Air Resources Board to provide excess steam from a $1,600-M W_{e}$, combined-cycle power plant to EOR projects in California. The costs of steam from such a project could be very low.

Table 2-2. CONVENTIONAL STEAM GENERATOR COSTS (1978 \$, $50 \mathrm{MBtu} / \mathrm{hr}$ Capacity)

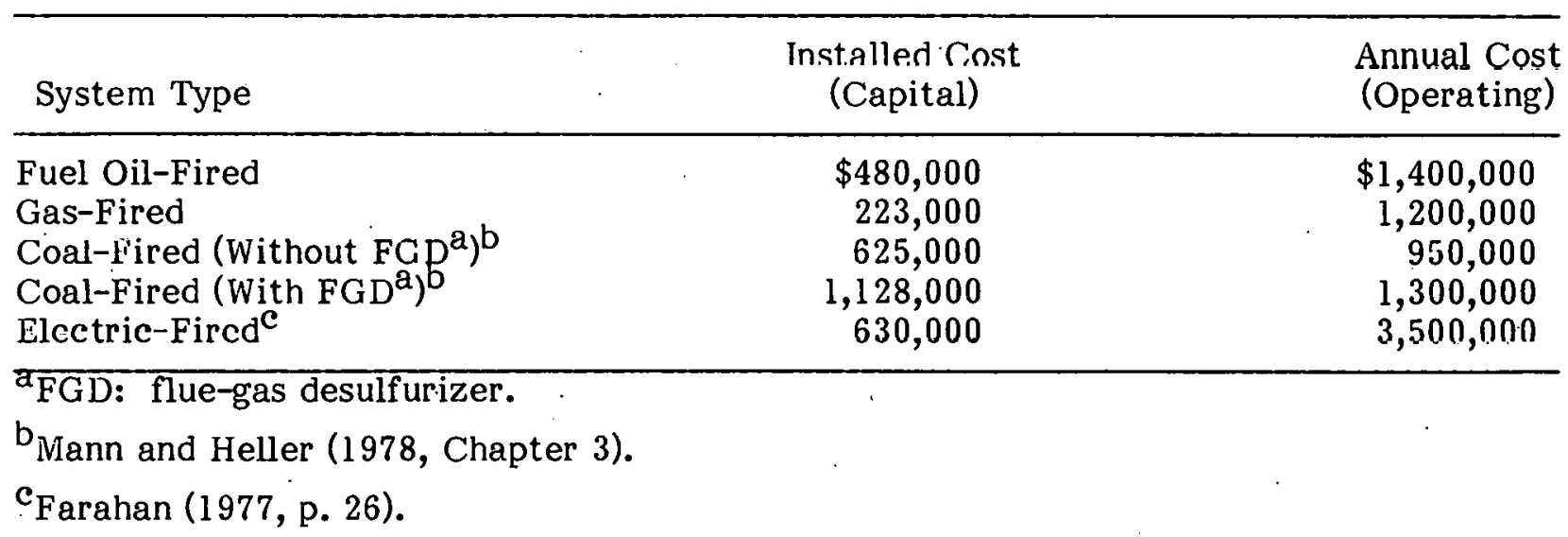

*The relatively low cost and high efficiency of insulation lead one to suspect that solar preheating of steam generator feedwater might be cost effective. Such preheating systems have the advantage of being noncritical to steam operations and of being operationally simple because nontracking collectors can be used. Such a preheating system might save $20 \%$ of the operating fuel costs. 
The use of $\mathrm{SO}_{2}$ serubbers for steam generators in California is one way to meet environmental requirements. Caustic soda tray scrubbers are manufactured to operator specifications by many of the same companies that manufacture the steam generators. Generator exhaust stacks are manifolded to the sciubber and relatively clean emissions are released through a single stack. Typically, a million dollar scrubber will serve seven to ten $50-\mathrm{F} / \mathrm{Btu} / \mathrm{hr}$ steam generators. Scrubber operating costs are approximately $\$ 1,000$ per day. Figure 2-5 shows a typical scrubber installation in a Kern County operation.

Steam produced by the steum generator is regulated and injected into a steam header near the generators. Steam pressure and flow rates to the distribution piping network are regulated depending upon formation and reservoir characteristics. Normally, steam is distributed at a pressure equal to the fracturing pressure of the formation (200 psi to suu ps1) plus an amouni to cover losses incurred in transmission. Both pressure and heat losses occur in stearn distribution piping to the injection wells; therefore, piping distances ideally should be small. However, the economy of clustering steam generators in a few locations throughout the field is substantial in comparison to energy losses in steam piping. Hence, piping distances as great as one mile are not uncommon. Steam distribution lines are normally 3 -in. steel lines, heavily insulated and aluminum jacketed. Heat losses in these pipes over normal distances amount to approximately $5 \%$ of the initial energy value of the steam. Pressure losses are about 0.02 psi to 0.05 psj per foot of pipe. Tilerefore, it is standard practice to generate steam at a pressure as much as 200 psi greater than that required at the surface of the injection well. Piping coverage in the field is significant. Allowance for space and access for piping, power distribution, and maintenance access must be considered in addition to the well placcment when determining land availability for thernal HOR systems, particularly when land-intensive solar EOK systems are to be used in fields that already are characterized by dense well spacings.

The injection well is simply a welloore lined with a steel casing to carry stean to the nil pool. The well is capped and supplied with at stexn pipe that is connected to the steam generator distribution line. Bccause of the large temperature variations inherent in steam injection, the wellhead and casing rnust be designed to allow for thermal expansion. Failure of the well casing or liner is the most cornmon cause of lost operating time in steam EOR systems.

\subsection{OIL FIELD OPERATIONS}

Approximately 227,000 bbl of crude oil per day are produced by steam EOR projects in California. A substantial portion of this production takes place in Kern County near Bakersfield. SERI personnel visited producers in this alea to ubtain first-hand observations of their EOR operations.

The largest field in the Kern County area is the 9,500-acre Kern River field, just north of Bakersfield. Twenty-two coinpanies operate wells in the Kern River field, although one -Gelly Oil Company-holds leases on approximately $60 \%$ of this area. The Kern iziver field has been steamed (initially steam soaked, now prinarily steamflooded) since the mid-1960s. Under foreseeable economic and technical conditions, the Kern iRiver fielci will produce oil for another $30-50$ years.

Oil produced from the wells in Kern County is normally heavily laden with formation water (80-90\% of the volume pumped) and must be separated from this water before it is piped to refineries. Each producer has an oil/water separation facility and a wastewater treatment facility. Oil/water separation is accomplished in a series of slightly heated 
settling tanks, in which the mixture is progressively purified from volumetric contents of $10-20 \%$ oil to a final purity of $99 \%$ oil ready for pipeline shipment. The separated water then is pumped to a wastewater treatment facility that removes the remaining oil sludge and dissolved minerals. Most of the water is reused in steam production. Excess water is disposed of in nonpotable aqueducts, such as the San Joaquin irrigation system.

Typically, producers directly employ only about $50 \%$ of the field work force. Installation of steam systems, wells, and pumps is handled by external subcontractors. Therefore, while the installation of a solar EOR system would be subcontracted, routine maintenance probably would be supplied by the permanent operating crew. 


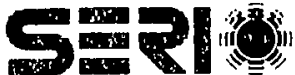




\section{SECTION 3.0}

\section{THE PERSPECTIVE OF THE PETROLEUM INDUSTRY}

The potential market for solar EOR lies in the petroleum-producing industry. Currently, there are approximately 17 oil companies using thermal EOR methods. The major share of the tertiary oil recovered, about $84 \%$, is produced by six oil companies: Getty, Shell, Chanslor-Western, Chevron, Texaco, and Miobil. Unless the proposed solar EOR systems, in place of or in conjunction with oil-fired generators, can meet the operational and financial criteria of these companies, no market will exist for such systems. For this reason, one needs to understand the requirements of the industry and the criteria used to make an investment decision of the magnitude required for installation of solar EOR systems. To appreciate the general perspectives and the specific EOR operational requirements of the petroleum-producing industry, interviews were conducted with officials of these companies. This section records and examines the industry's perspective of solar EOR. Table 3-1 lists the companies interviewed as well as the number of barrels of oil each produced in 1977 using thermal EOR methods.

Table 3-1. SURVEYED PETROLEUM COMPANIES

\begin{tabular}{lc}
\hline \multicolumn{1}{c}{$:$} & $\begin{array}{c}1977 \\
\text { Thermal EOR } \\
\text { Oil Production } \\
\text { (bbl/d) }\end{array}$ \\
\hline Companies Contacted & 80,000 \\
Getty Oil Company & 31,000 \\
Shell Oil & 31,000 \\
Standard of California & 31,000 \\
Chanslor-Western & 14,000 \\
Mobil Oil & 6,000 \\
Tenneco & 3,000 \\
Occidental Petroleum & 1,000 \\
Exxon Petroleum & \\
\hline
\end{tabular}

Three caveats should be noted. First, the interviews were held mostly with production officials, rather than with researchers, because we were more concerned with production requirements. Second, all of the companies represented discussed their California operations because this is where the vast majority of steam EOR is conducted. Third, the interviews were conducted prior to President Carter's announced decision to decontrol heavy oil production.

\subsection{INTEREST IN SOLAR EOR}

Many of the petroleum companies have made some study of the possible use of solar EOR. The main impetus for their interest seems to have been the recent DOE Program Opportunity Notice (PON) for the development of a solar-powered steam generation system for EOR. A second source of oil company interest has resulted from strong marketing efforts by various solar collector manufacturers, again largely in response to 
the PON. One result of these interviews was that a great deal of information on the economic and technical facets of solar energy systems was passed to the oil company officials by the SERI interviewer.

Although several of the oil company personnel interviewed had been contacted by collector manufacturers regarding the possibility of submitting a joint response to the demonstration PON, most of those people were in the corporate planning and development divisions of their companies. Mlost of the personnel contacted for the SERI study were in the production or operations divisions. This cross-section provided the SERI study with an overview of the petroleum producers' opinions of the feasibility of EUR and what efforts are being made within their divisions to learn about the application of solar energy. Not surprisingly, different divisions of the same company sometimes professed strikingly different opinions. In one case, a production official of one large oil company was clearly not interested in solar EOR while the rcsearch division of the same rompany was preparing a submission to the PON.

Although production people may have had a general perception of how solar EOR might operate and although they had calculated preliminary estimates of the possible economics of representative systems, they generally suggested that any significant corporate efforts regarding solar EOR would occur at the corporate R\&D level. For cxamplc, Chevron's Oil Field Research Division was the lead corporate entity in examining the feasibility of solar EOR within Standard of California (Chevron). The producers generally agreed that solar EOR is at the $R \& D$ stage and any serious research or budget allocation would be in the research division, not through the commercial operations divisions. One producer suggested that no corporate $R \& D$ dollars should be allocated to solar EOR if the probability of success were thought to be low; in the near term (i.c., five years), the uncertaintics surrounding solar EOR technologies were too great for the probability of success to be considered seriously, and he had not yet considered it for the longer term (10 to 20 years).

The nonpolluting qualities of solar encrgy systems and their benign effect on air quality standards were pointed out by some interviewees to be an obvious advantuge of solar EUK systems. However, oil company officials argued that air quality regulations are of questionable duration and stringency. Although the producers must spend an enormous amount of time and money to obtain burner permits in California, they all clairned that they were obtaining or already had enough permits to meet their production requirements.

\subsection{INCENTIVE PROGRAMS}

As represented by the interview sample, the petroleum industry has specific preferences regarding federal financial incentives to increase EOR production. The investment tax credit and other advantageous tax treatments, such as accelerated depreciation, are viewed favorably by the petroleum industry. Obviously, the industry would respond most favorably to the decontrol of oil prices.* Many producers claim that decontrol would be the single most important incentive to enhanced nil rennery. However, they point out that it would not be particularly advantageous to solar EOR unless special provision were

*See, for example, the comments of George H. Galloway, President of Amoco Production Co. (Anonymous 1978a). 
made for heavy petroleurn, which would benefit all types of thermal EOll. For this reason, some spokesper'sons noted that even though an increase in the price of petroleum would make EOR more attractive, it would not be sufficient to give solar EOR a decider advantage. An increase in oil prices would benefit all the EOR processes. Solar EOR would benefit more from solar equipment cost reductions and demonstrated reliability than from increased oil price levels.

The petroleum industry is more receptive to indirect incentives, such as tax benefits, than to direct government participation programs, such as demonstration projects and cost-sharing incentives. Historically, the petroleum corporations have been averse to government participation in the production and operation segments of their industry. Government demonstration programs, loan guarantees, and cost-sharing programs require the release and sometimes publication of information that companies otherwise would consider proprietary. These programs also involve the assignment of additional personnel to the government reporting requirements that accompany them. SERI interviews with oil company personnel strongly suggest that tax incentive government programs are preferred over direct government intervention programs (e.g., subsidy).

Many petroleum industry officials expressed the sentiment that if a technology is feasible, they would prefei to develop it without direct aid from the federal government. To this end, John Deutsch, then-acting Assistant Secretary for Energy Technology, reflected the industry's sentiment when he explained DOE's reduction in the EOR research budset with the statement, "Secondary recovery is better handled by the private sector." He elaborated in his submission to Congress:

The FY 1980 budget is intended to be the minimum level required to naintain a visible presence in the industry .... At the time the Department of Energy was formed, the enhanced oil recovery activity was based on a strategy emphasizing near-term production goals. However, the Economic Regulatory Administration has subsequently devised a program of regulatory incentives designed to stimulate commercialization of near-term technologies by the private sector. (Quoted in Meyers 1979)

Several state and federal prograins were mentioned which have potential effects on thermal EOR projects that could influence the decision of a firm to invest in solar EOR. One obvious inducement is the $10 \%$ additional federal investment tax credit for using solar equipment in industrial applications. With it, the total investment tax credit available could be 20\%.* Sume of the producers were not aware of this additional tax writeoff and of those who were, some did not consider it in evaluating the economics of solar EOR. Among those who were aware of the tax benefits, many pointed out that their firms were hesitant to rely on incentives whose durations were uncertain and subject to political manipulation. For instance, they noted that the California law which encourages the use of solar energy expires in five years.

* President Carter recently proposed a substituted $15 \%$ additional tax credit (making the potential additional credit 25\%) for industrial process heat systems, but it is unclear whether this credit will apply to EOR applications. Recent inquiries at the Internal Revenue Service disclosed that the $10 \%$ additional credit is subject to initial interpretation, including the allowance of the credit only on specific solar cquipmcnt costs beyond conventional system replacement costs. Additional clarification and tax guidance are needed in this area. 
The oil producers generally agree that the Economic Regulatory Administration's (ERA) proposal for recouping $75 \%$ of capital costs to a maximum of $\$ 20$ million and the freedom to sell conventional production from tertiary fields at world oil prices would benefit EOR activities (Anonymous 1978c, 1979b, 1979c). Earlier ERA proposals to permit only the incremental EOR oil to be sold at world prices were heavily criticized as too burdensome and uneconomic to be attractive to the oil companies. As noted in the Oil and Gas Journal (Anonymous 1978d):*

[T] he producers declare that new rules of the Economic Regulatory Administration freeing incremental enhanced production from price controls will do little or nothing to increase tertiary projects. The price of all crude produced in an enhanced project must be freed, or full-scale operations won't be undertaken, producers say.

To date, Shell Oil has received permission to obtain market clearing prices for the incremental increase in crude oil produced from tertiary projects (Anonymous 1979d). Three more companies have had applications approved and eight other companies have applied for market prices for incremental production. Capital cost recoupment regulations were approved recently by the ERA, but industry sentiments seem to be less enthusiastic about these programs and more in favor of price decontrol programs (Wilson 1979; Anonymous $1979 \mathrm{e}$ ).** An associated statement repeatedily heard was that government pricing regulations should be made simpler to understand and follow.

The oil company production officials expressed little interest in a government-funded demonstration. Numerous reasons were cited for their lack of interest but unattractive economics, uncertain potential, and the general preference to avoid government involvement were most of ten given. The oil producers require an acceptable level of confidence in the ability of solar collector manufacturers to reduce costs sufficiently to make systems affordable. Although the oil producers are basically interested in the possible commercial use of solar systems, they feel more $R \& D$ is needed at this time. They state that the present economics are not attractive enough, and the level of cunfidence in the technology is so low that not even a demonstration is warranted at this time. Their major concerns are high front-end costs, uncertain operation costs, reliability, land availability, and performance. In addition, oil producer's prefer to develop technologies and processes with minimal government involvement. Many said that working with government programs to develop energy sources requires more time and expense than with no government involvement. Reporting requirements of ten are cited as being a disincentive. Still, these same oil producers admitted that they would not be unalterably opposed to accepting government subsidies for building a solar EOR demonsiration facility. The contradiction was clear and recurring: In general, the of ficials interviewed were opposed to government involvement in their operations, but they were willing to accept government funds to advance their research and production operations.

*See also the testimony of James D. Henry testifying before the ERA on behalf of the Atlantic Richfield Company regarding "Additional Price Incentives for Tertiary Enhanced Recovery Techniques," Washington, D.C., September 27, 1978.

**Again, these interviews with oil company officials were conducted prior to the President's decision to decontrol oil prices over the next few years. 


\subsection{ENVIRONMENTAL CONSIDERATIONS}

In late December 1978, Getty Oil's crude-fired steam generators were found to be violating Environmental Protection Agency (EPA) standards. In response, Getty shut down 62 of its oil-fired generators for emission violations during that 24-hr period (Anonymous 1979f). Getty could have installed additional scrubber capacity or burned low-sulfur crude oil, but chose instead to shut down those generators plus an additional 36 generators, the latter for economic rather than environmental reasons. Getty officials have stated that they could not afford to produce crude oil at lower-tier prices given the costs of meeting environmental regulations (Anonymous 1979g). With this episode as background, petroleum company officials were asked to assess solar EOR in the context of its environmental benefits.

Currently, the oil companies have three means for meeting air quality standards. The first is to install $\mathrm{SO}_{2}$ scrubbers, with additional scrubbing capacity to meet future emission controls. This technology is well known and is widely used to meet air pollution standards in the California oil fields.

The second alternative is to adopt cleaner-burning fuels, such as low sulfur oil. Burning low-sulfur fuel oil does not appear to be a preferred solution at this time because of its high price. Producers currently burn their own crude production; in particular, they burn their lower-tier production which is also unrefined and therefore does not carry an entitlements obligation. According to Henwood, "The incremental cost of scrubbing may be higher than the incremental cost of desulfurization. But, due to the entitlements program, scrubbing is by far the more attractive choice financially" (Henwood 1978, p. 57). Possibly, desulfurization no longer will be incrementally less attractive than scrubbing when heavy crude prices are decontrolled. Decontrol would permit the price of all crude to rise to a market clearing level. Hence, burning low-sulfur oil may become more economically competitive with scrubbing as ways of controlling emissions.

The third alternative is to shut in production. Two government policies repeatedly were cited as contributing to this possible action: (1) the government-regulated pricing mechanism, and (2) air quality standards and the associated costs of control. Under present regulations, producers such as Getty who were producing prior to 1972 are receiving lower-tier prices for the number of barrels produced at that time while production initiated after 1972 is sold at upper-tier prices. According to petroleum officials, the rising costs of production and the restricted selling price are making production uneconomic, making it economically attractive to shut in their wells. Some producers go so far as to state that if compliance with the air quality standards becomes cost prohibitive, then shutting in production may force government agencies to relax the environmental standards to prevent shortage of crude.

The oil producers generally consider the costs of environmental regulations when evaluating EOR alternatives. Producers do not view environmental issues alone, however, as a sufficient stimulus to move solar EOR to a commercial status. It is likely, therefore, that the environmental benefits of solar EOR may not be as persuasive an incentive as originally perceived because several more familiar alternatives exist that are now both technically and economically feasible. Some officials state that the industry simply will not be driven to install more costly methods by environmental regulations alone. It would rather shut in production before producing at a loss and wait for political pressure to force a relaxation in environmental standards. At present, producers maintain they can meet all air quality standards with additional scrubber capacity, which could be added at a lower cost than that of an equivalent solar system. The critical 
factor, according to the industry producers, will be relative costs. If a solar system can deliver the energy required for their operations at a cost competitive with or lower than other alternatives, the industry will use it.

The largest environmental quality obstacle to conventional thermal EOR is the difficulty in obtaining permits to burn high sulfur oil in the steam generators (see Sec. 4.0 for details). The oil producers cite the regulatory process and its time delays as particularly costly. One firm has the equivalent of three staff members dedicated to obtaining the necessary permits.

\subsection{FIN ANCING OPTIONS}

The commercialization of solar EOR depends to a large degree on the economics of alternative forms of EOR and other investment opportunities. 'I'he investment economius of EOR specifically depend on the level of risk, uncertainty, and the ability to gencrate sufficient cash flow to produce a minimal, acceptable rate of return (See Sec. 6.0). These criteria hold true whether capital is generated internally or exlerually. Oil company officials were asked how their firms might choose to finance solar EOR were it to appear technically and economically attractive.

Conventional practice in the petroleum industry has been to finance EOR projects internally with cash generated from other income-producing projects. This may be standard practice because most EOR projects have been of the thermal recovery kind that require relatively modest capital expenditures. Chemical flooding and solar EOR projects promise substantially higher front-end expenditures for injection materials and equipment, respectively. For these methods, alte:native financing mechanisms may be neeried,

Generally, the major petroleum producers finance capital expenditures with the cash flow from total operations (ICF 1979). According to the DOE prrspectivc, cash financing will be required for advanced energy projects, and the private sector should pay for these potentially profitable enterprises; unfortunately, private sources of capital are rcluctant to assume the technical and financial risks involved (Corrigan 1979). Hence, it might be extremely difficult for the oil companies to borrow money without federal government support (see Sec. 6.0). For high-risk projects to advance, the federal government may have to provide financing or loan guarantees if commercial money is not available.

Given fluctuations in investment capital availability (Corrigan 1979; Tanner 1975) and the risks and uncertainties of solar EOR, the willingness of the private lending sectur to finance commercialized solar EOR operations in the near term without fedcral financial assistance must be seriously questioned.* Whether the private or public sector pruvides the capital necessary for such Installations depends vil the eurrent state of the tcchnology and its capability to meet investment criteria. Oil company officials were skeptical that these conditions could be met under their present preferred equity financing arrangements, and they have begun to explore other financial arrangements (Simpson 1979; Gibbs and Sroka 1978). For EOR projects in general, the currently perceived technological risks and uncertain costs lead operaturs to cliouse more certain or higher payoff opportunities, especially those for exploration and nonpetroleum ventures (Lewin and Associates 1976a, p. III-6).

*Corrigan (1979) reports similar sentiments for both lending institutions and energy producers. 


\section{SECTION 4.0}

\section{LEGAL AND ENVIRONMENTAL ISSUES RELATED TO SOLAR EOR}

Three issues have been identified in previous EOR reports as presenting potential barriers to the expansion of oil-fired thermal EOR activities: (1) unitization of oil fields, (2) water supply and disposal, and (3) air pollution resulting from the combustion of high sulfur crude in oilfield steam generators (Office of Technology Assessment 1978; National Petroleum Council 1976). A fourth issue, which is unique to solar EOR, involves the large land areas required for the solar collector arrays and the rights of lessees under the terms of an oil and gas lease to utilize the surface land for such purposes. This section addresses these four issues.

Although the unitization and water issues are not peculiar to solar EOR, they are briefly evaluated here because of their potential for hindering the development of any thermal EOR project. Air quality control is considered for two reasons. First, conventional oilfired thermal EOR systems produce atmospheric pollutants. The key issue is the extent to which air quality standards will limit the use of such systems. If air quality standards do prove to be a significant obstacle to the expansion of oil-fired thermal EOR activities and no fossil-fueled systems are included for nighttime operations, then solar Eoli. may becone a more attractive option because it produces no atmospheric pollutants. If new fossil-fired therinal EOR systems can be designed to comply with the new air quality regulations, then the air quality motivation for using the solar system becomes less pressing. Second, preliminary technical feasibility assessments indicate that solar EOR systems may require oil-fired backup systems for cloudy day and nighttime operation. In this case, the analysis of air quality regulations discusses the possibility that air quality rules might limit the construction of the solar hybrid systems (a combination of solarand fossil-powered steam generating boilers).

\subsection{SURFACE RIGHTS OF LESSEES UNDER OIL AND GAS LEASES}

In most cases, the land use required for thermal EOR operations is small.* Often, surface activities such as grazing and agriculture can be conducted without interfering with the thermal EOR activities. Solar EOR activities, however, require large land areas for the collector arrays. A $50-\mathrm{MBtu} / \mathrm{hr}$ solar system is estimated to require anywhere from 17 to 30 acres of land.** Since solar systems require so much land area, what are the rights of oil operators with respect to surface land usage?

There are two aspects of land ownership: surface rights and mineral rights. Surface rights entitle the owner to usc the surface land for grazing, agriculture, residential or commercial development, or whatever else he may desire subject to local zoning regulations, Mineral rights, which oommencc at the suifact and extend to indeterminate depths below the surface, entitle the owner to develop minerals, oil, and gas below the surface, again subject to zoning regulations. An individual who owns both the surface

*In some fields, such as Getty's Kern River location, the well spacing is so tight that solar EOR activities, which require more room than the fossil-fired steam generator systems, might be restricted by a lack of space.

**See Sec. 5.0 for system sizing details. 
rights and mineral rights may separate the two by selling a "mineral deed" to another" party. A typical mineral deed grants a specified number of acres "... together with the right of ingress and egress at all times for the purpose of mining, drilling, exploring, operating, and developing said lands for oil, gas, and other minerals, and storing, handling, transporting, and marketing the same therefrom with the right to remove from said land all of Grantee's property and improvements" (Wheeler and Whited 1975, p. 130).

To develop mineral resources without surrendering his interests, the mineral owner can lease the exploration and production right to another party who specializes in such operations. Under the terms of a representative oil and gas lease, the lessee has "express" and "implied" rights. Rights are express if the parties to the lease have specifically recognized or granted the rights in the lease. In a sample oil and gas lease, the lessee has the express right to use the surface land "... for the sole and only purpose of mining and operating for oil and gas, and laying pipelines, and building tanks, power stations and structures thereon to produce, suve and lake aure of suid products ..." (Whenler and Whited 1975, p. 133). Although the lessee has the express right to build "power stations and structures" on the surface land to produce oil, the typical lease says nothing about the specific right to use large surface land areas for solar power collcctors. If a lessee wanted to use a solar system to produce steam and a mutual agreement could not be obtained from the surface land owner, the issue would have to be adjudicated.

The lessee's rights are implied if the parties to the lease have not expressly provided for them but the law recognizes that they exist by virtue of the nature of the transaction. For example, the right to build a road to carry equipment to the drill site may not be expressly stated, even though it would not be reasonably possible to develop the facility without the road. The law implies, therefore, that the lessee has the right to build a road. In general, legal precedent recognizes that, even without express grant, the lessee has the right to use such methods and as much of the surface as may be "reasonably" necessary to remove the oil or gas, while retaining due regard for the righls of the surface owner. The term "reasonable" is the key to whether a lessee has the implied right to use large surface areas for solar collector arrays. If reasonable alternutives to solar systems exist, then the lessee may not have an implied right lo fmuloy such system3. The use of solar systerns, therefore, may depond upon the consent of the surface land owner.

Even though the use of solar systems may not be an implied right of the lessee if reasonable alternatives exist, judicial precedent holds that the lessee does have an implied right to use the surface for EOR activities. The Appellate Court of Illinois has held that, "The court would violate fundamental principles of conservation to insert by implication a provision that lessee is limited to production of such oil as can be obtuined by old fashioned means, or by so called primary operations."* Even though this decision was written in 1950, OTA analysts have argued that "the same rationale would apply to more modern methods of enhanced resuvery, even though these methods might involve somewhat greater use of the surface and different types of injection substances" (Office of Technology Assessment 1978, p. 201).

In summary, there is no clear answer to the problem of the rights of lessees with respect to using the surface for solur collector arrays. Although the lessee has an express right to build power stations and an implied right to conduct EOR, there is no clear judicial

*Carter Oil v. Dees, 92 N.E. 2d, 519 (1950); cited in Office of Technology Assessment 1978 , p. 201. 
precedent dealing specifically with the solar issue. If it should go to court and the court rules that the lessee does have an implied right to use the surface for solar thermal EOR, negotiations might still be required to determine fair compensation to the surface owner for loss of the use of the surface.

The key issues, then, concerning land use are the current utilization of the surface and whether reasonable alternatives to the solar system exist. If the surface estate has other valuable uses and there are reasonable alternatives to the solar-powered system, problems could result for solar applications. If these conditions do not apply, the lessee may face minimal opposition. Second, the general issue presented by solar EOR is not new, even though there is no specific judicial precedent. Ultimately, this issue may have to be settled in court, similar to other issues dealing with the surface rights of lessees under oil and gas leases. As Gray has stated, "Despite a long history of experience and a fairly extensive body of judicial precedent, the question of whether, to what extent, and under what circumstances the oil and gas lessee may occupy and use the surface of the leased premises to find, produce, and remove the oil and gas therefrom, and dispose of waste products, now seems to arise more of ten than before, and frequently the answers appear more elusive than ever" (Gray 1975, p. 277).

\subsection{UNITIZATION}

Nearly all oil reservoirs in the United States have multiple ownership. For efficient EOR operations, the reservoir is often treated as a single operating unit by integrating the multiple owners' interests, either voluntarily or through compulsory requirement. The integration of these interests is called "unitization." When a reservoir is unitized, one producer generally is designated the operator. All the other parties with an interest in the field share the investment and operating costs and the field output in proportion to the amount of the reservoir beneath their original drill tracts. In the major oil-producing states of Texas and California, the Texas Railroad Commission and the California Division of Oil and Gas, respectively, are authorized to approve unitization agreements.

In the EOR literature the main problem concerning unitization is the absence or weakness of compulsory unitization statutes in some states. In California and Texas, owners of relatively small interests can prevent EOR activities by refusing to accept their share of the risks ano expenses associated with a joint EOR venture. This problem may be particularly acute for a proposed solar EOR project because of its high risks and uncertainties. The problem may be heightened when field ownership is extremely fragmented. Unitization is further complicated when the lessee does not have the right to unitize the interest of the lessor without the latter's express consent; i.e., even if all the various lessees can agree to unitize, the process can be impeded by a recalcitrant lessor unless the state has mandatory unitization laws. In California, however, ". . to ensure orderly well spacing, and equitable drainage from the several leases overlying a field or pool, most leases grant the lessee the right to pool or consolidate lands into units. .." (Calif. Div. of Oil \& Gas 1976, p. 1).

Lessees or lessors may be reluctant to have their interests unitized even though unitization for EOR purposes, in theory, should benefit all interest owners. Several factors motivate such reluctance. First, in some states an operator may be liable to parties who refuse to join a unit if EOR reduces the oil production of the nonjoiners. In fact, few nonjoining interests have ever made damage claims against unit operators and even fewer damages have ever been awarded. Second, lessees have obligations to the mineral owners; for example, to conduct "prudent operations." If oil were to drain away from a mineral owner's lease due to EOR activities, the owner might claim that the lessee was 
not conducting prudent operations and file a damage suit. However, state-approved unitization agreements usually protect operators from such suits unless the damage results from operator negligence. A third factor impeding voluntary unitization centers on the agreement on cost and production sharing. Each operator's share of production is in direct proportion to the amount of productive oil pay zone beneath his original surface tract. Determination of exact proportions is difficult and has led to long and labored negotiations. If one party claims that it deserves production greater than that determined on the pay zone criterion, negotiations could break down and voluntary unitization could become impossible.

As a result of the problems in achieving voluntary unitization, many states have adopted compulsoly unitization statutes, which empower a state commission to compel all owners of a field to unitize once there has been voluntary agreement among a specified percentage of interest owners. The required percentage ranges from $60 \%$ in New York to $85 \%$ in Mississippi. Texas, a major oil producing state, has no compulsory unitization statute. In California, the coinpulsory unitization statutes are so restrictive as to be ineffective. Thus, Texas and California, which have a large fraction of the nation's EOR potential, are two states in which unitization could be most difficult.

A revicw of the unitization literature has indicated potential difficulties in achieving unitization for $E O \mathrm{R}$ projects. However, discussions with oil and gas industry of ficials in California indicate that unitization problems are much more potential than real. One official at the California Division of Oil and Gas said that unitization has not been a major issue in California since the 1950s; similar statements were made by a California Energy Commission staff member and a Getty Oil Company official. According to the Getty official, the Kern River field has 22 operators and is not unitized. Each company conducts its own EOR activities and no serious technical or legal problems have arisen.* Informal operating agreements are reached which appear adequate for each operator's nccds.

As noted, the potential for unitization problems would appear to be greatest in oil fields having highly fragmented ownership. 'l'able 4-1 shows that of $1 \dot{b}$ heavy oll flelds, 10 (marked by asterisks) are more than $75 \%$ owned by 5 or fewer operators. Since the oil fields in California do not seem overly fragmented, the prospects for achieving unitization to conduct solar EOR may not be as difficult as some of the literature has suggested.

\subsection{WATER SUPPLY AND DISPOSAL}

All steam injection EOR processes, whether powered by solar energy or by conventional tuels, require large quantities of fresh water. As many as six barrels of freslı walel cun be needed for each barrel of oil recovered, a demand which could strain the capacity of local water supplies and have a significant environmental effect in some regions (Office of Technology Assessment 1978, p. 98). Solar steam EO projects will have large water requirements which must compete with other domestic, agricultural, and industrial uses. Such competition could be particularly severe for potential solar EOR sites in California, Texas, and western Louisiana, where water supplies already are limited. In

*This statement is not meant to imply that problems have not occurred in fields other than Kern River. The Point here is that successful EOK activities can be conducted without unitization. 
Table 4-1. ESTIMATED PERCENTAGE OWNERSHIP OF HEAVY OIL FIELDS IN CALIFORNIA

\begin{tabular}{|c|c|c|c|c|c|c|c|c|c|}
\hline Field & Chevron & Ge!ty & Shell & Union & Mobil & 'Texaco & Santa Fe & other & Total \\
\hline Belridge South & - & - & - & - & 37 & - & - & 63 & 100 \\
\hline *Brea Olinda & - & 3 & 30 & 48 & 3 & - & 5. & 10 & 100 \\
\hline Casmalia & 7 & - & - & 51 & - & - & - & 32 & 100 \\
\hline Cat Canyon & 19 & 15 & 11 & 15 & 2 & 6 & - & 32 & 100 \\
\hline *Coalinga East & 43 & - & 57 & - & - & - & - & - & 100 \\
\hline Coalinga West & 44 & - & 31 & - & - & 13 & - & 12 & 100 \\
\hline *Cymric & 67 & 4 & - & 2 & 9 & - & - & 18 & 100 \\
\hline Eđison & 23 . & 2 & - & - & 6 & 2 & - & 67 & 100 \\
\hline Kern Front & 19 & 24 & 3 & - & $\delta$ & 5 & 6 & 35 & 100 \\
\hline *ISern Kiver & 18 & 67 & 8 & - & - & - & 2 & 5 & 100 \\
\hline *iveKittrick & 23 & 67 & - & 7 & - & - & - & 3 & 100 \\
\hline Midway Sunset & 18 & 5 & 9 & 2 & 7 & 3 & 21 & 35 & 100 \\
\hline *iviount Poso & - & - & 87 & - & - & - & - & 13 & 100 \\
\hline *orcutt & - & 5 & 5 & 89 & - & - & - & 1 & 100 \\
\hline *San Ardo & - & - & - & - & 50 & 50 & - & - & 100 \\
\hline *Santa IVarja Valley & 1 & - & 47 & 23 & 2 & 4 & - & 23 & 100 \\
\hline
\end{tabular}

Source: Goldman Sachs Research (1976, p. 10).

Note: Totals may not add to 100 due to rounding.

*Indicates that five or fewer oil companies own more than $75 \%$ of the field. 
addition to potential water supply problems, solar EOR operators also must devise methods to dispose of wastewater in an environmentally acceptable manner.

In California, the source of most water for steam injection is formation water, that is, underground water produced along with the oil; this can be as much as $90 \%$ of the liquid extracted during pumping operations. Although this formation water contains high concentrations of total dissolved solids, it can be treated to make it suitable for steam production.

California appears to have sufficient formation water to expand thermal EOR activities. Table 4-2 indicates that there is a surplus of formation water in most fields. Of 45.8 million barrels of formation water produced in the Kern Front field, only 3.1 million barrels, or less than $7 \%$ of production, were used for steam injection, thus leaving over 40 million barrels of formation water available for increased thermal EOR activities. In the Kern Kiver field, abuut $580,000 \mathrm{bbl} /$ duy of formation water are being reclaimed by Chevron and Getty (Calif. Div. of Oil \& Gas 1977, p. 10). About $450,000 \mathrm{bbl} /$ day of this water are being used for steam generation, and the surplus is of sufficient quality to be disposed of in an agricultural canal. In some oil fields, additions to the formation water supply might be necessary if EOR expansion continues but, in general, the net water demand for thermal EOR activities should remain less than the supply for the foreseeable future.

Table 4-2. WATER BALANCE FOR THE 11 LARGEST THERMAL OLL FIELDS IN CALIFORNIA ${ }^{\mathrm{a}}$

\begin{tabular}{lccccc}
\hline & $\begin{array}{c}\text { Formation } \\
\text { Water } \\
\text { Produced } \\
\left(11^{6} \mathrm{bbl}\right)\end{array}$ & $\begin{array}{c}\text { Thermal EOR } \\
\text { Injection } \\
\left(10^{6} \mathrm{bbl}\right)\end{array}$ & $\begin{array}{c}\text { Water } \\
\text { Flood } \\
\left(10^{6} \mathrm{bbl}\right)\end{array}$ & $\begin{array}{c}\text { Subsurface } \\
\text { Disposal } \\
\left(10^{6} \mathrm{bbl}\right)\end{array}$ & $\begin{array}{c}\text { Water Available } \\
\text { for EOR Expansion } \\
\left(10^{6} \text { bbl }\right)\end{array}$ \\
\hline Kern River & 236.2 & 139.5 & 2.0 & 12.6 & 82.1 \\
Midway Sunset & 85.8 & 49.2 & - & 18.6 & 18.0 \\
San Ardo & 101.1 & 44.0 & - & 64.1 & -7.0 \\
So. Belridge & 98.1 & 29.0 & - & 9.5 & 59.6 \\
Mt. Poso & 95.4 & 13.0 & 3.3 & 56.4 & 22.7 \\
Mckittrick & 17.0 & 9.7 & - & - & 7.3 \\
Yorba Linda & 19.6 & 8.3 & - & 0.1 & 11.2 \\
Cat Canyon & 26.5 & 5.9 & 13.6 & 14.6 & -7.6 \\
Cymric & 24.4 & 3.8 & 0.3 & 0.3 & 2.0 \\
Coalinga & 47.3 & 3.1 & 10.7 & 10.7 & 7.2 .8 \\
Kelin Floul & 45.8 & 3.1 & - & - & 42.7 \\
\hline
\end{tabular}

${ }^{a_{S}}$ Source: Henwood (1978, p. 25) and Calif. Div. of Oil and Gas (1977).

In most fields, then, there are no short-run physical constraints to the amount of water required to operate thermal EOR systems, nor are there technical problems with water purification. The major constraints to water supply are the cost of treating formation water to allow its use in steam generator operation (Henwood 1978, p. 24) and the environmental regulations on water disposal. To be turned to steam, the formation water needs to be treated to achieve proper mineral content and pH level (Interstate Oil Compact Commission 1974, p. 174). Disposal of surplus formation water is routinely 
accomplished by injecting it into salt water aquifers, injecting it back into the oil producing zone, or discharging it to surface aqueducts. These practices are regulated by the EPA under the 1972 Amendments to the Federal Water Pollution Control Act and the 1974 Safe Drinking Water Act, which require that a permit be obtained prior to discharging wastewaters to ensure that water quality can be maintained (National Petroleum Council 1976, p. 67). To date, no significant problems due to formation water disposal have arisen, nor are any expected within the foreseeable future.

\subsection{AIR QUALITY REGULATIONS}

Burning oil to produce steam for thermal EOR activities produces atmospheric pollutants, including sulfur dioxide $\left(\mathrm{SO}_{2}\right)$, nitrogen oxides $\left(\mathrm{NO}_{\mathrm{x}}\right)$, hydrocarbons $(\mathrm{HC})$, carbon monoxide $(\mathrm{CO})$, carbon dioxide $\left(\mathrm{CO}_{2}\right)$, particulates, and photochemical oxidants. Depending on the number of steam generators, the sulfur content of the oil burned, and the atmospheric conditions, these emissions can have significant localized effects in areas already in violation of National Ambient Air Quality Standards (NAAQS). Unless effective pollution control techniques are used or compensating emission reductions are made elsewhere in the affected areas, air quality standards may prove to be a significant constraint to the expansion of oil-burning thermal EOR projects in areas such as California's Sun Joaquin Valley, which is already in violation of several NAAQS.

A widely cited rationale for solar EOR is its potential air quality benefit. This motivation would be substantially undermined if the solar EOR system required an oil-fired backup steam generator. Whether solar EOR will require such a system, however, is not yet decided, nor have the comparative economics of possible alternative systems for meeting emission standaras been completely explored. This subsection surveys the current permitting processes for new sources of air pollution to determine whether expansion of conventional oil-fired thermal EOR will be constrained significantly by various air quality regulations; it also examines the permitting process for hybrid solar EOR systems in the context of relevant air quality regulations.

\subsubsection{The Clean Air Act}

The Clean Air Act (CAA), as amended in 1977, is the major federal law addressing air quality standards. Under its terms, the EPA has the authority to divide the nation into Air Quality Control Regions (AQCR) and to set National Ambient Air Quality Standards for six "criteria pollutants." AQCR which meet the NAAQS for a given criteria pollutant are termed "attainment," or "clean air," areas for that pollutant. Any new source of air pollution in an attainment $A Q C R$ is subject to the Prevention of Significant Deterioration (PSD) regulations. AQCR which do not meet the NAAQS for a given criteria pollutant are termed "nonattainment," or "dirly air," areas for that pollutant. In nonattainment AQCR, any new source of air pollution is subject to a set of Nonattainment Regulations.

'To allow states to administer their own air quality programs, the CAA mandates that each state is responsible for submitting a State Implementation Plan (SIP) to the EPA to explain how it will achieve the NAAQS for each nonattainment AQCR and how it will maintain the NAAQS for each attainment AQCR. A major component of the SIP is the New Source Review (NSR) plan for reviewing new air pollution sources to (1) guarantee that such sources will not prevent attainment of NAAQS in nonattainment AQCR, and (2) will not lower air quality standards in existing attainment AQCR. If the EPA approves the SIP, it delegates the authority to administer the permitting process to the state. 
To understand how these rules may affect the implementation of conventional, oil-fired EOR systems and solar EOR systems with fossil fuel-fired backup, it is necessary to examine the CAA in more detail.

\subsubsection{Ambient Air Quality Standards}

The EPA has set NAAQS for six criteria pollutants-photochernical oxidants (ozone), CO, $\mathrm{NO}_{\mathrm{X}}, \mathrm{SO}_{2}$, total suspended particulate matter (TSP), and HCs. (The exact standards for these pollutants are found in Appendix A, "Ambient Air Quality Standards.") Under the terms of the CAA, states are allowed to set ambient air quality standards that are more -but not less-stringent than the NAAQS. In many cases, the California ambient air guality standards are more stringent than the federal standards; in addition, California has ambient air quality standards for sulfates, lead, hydrogen sulfide, ethylenc, and visibility reducing particulates.

To classify each $\mathrm{AQCR}$ as attainment or nonattainmenl, the CAA requires cach state to report the attainment status of their AQCR to the EPA. EPA figures sho' that the Kern County portion of the San Joaquin Valley Air Basin (see Fig. 4-1) is nonattainment for oxidants, $\mathrm{CO}$, TSP, and $\mathrm{SO}_{2}$ (see Table.4-3). New sources in Kern County that could emit large quantities of these pollutants will be subject to the nonattainment permit regulations for them. Assuming that Kern County does not violate the NAAQS for HC and $\mathrm{NO}_{\mathrm{x}}$, any new source which could emit large quantities of those substances will be subject to the PSD permit regulations for them. Moreover, if a new source in Kern County could emit large quantities of $\mathrm{NO}_{\mathrm{x}}$ and $\mathrm{SO}_{2}$, it would be subject to both PSD regulations (for $\mathrm{NO}_{\mathrm{X}}$ ) and nonathainment regulations (for $\mathrm{SO}_{2}$ ).

\subsubsection{State Implementation Plans (SIP) and New Source Review (NSR)}

An acceptable sip includes a ylan for the attainment of $\mathrm{NA} A \mathrm{As}$, emissim limitations and compliance schedules, a syslen for monitoring ambient air guality, provisions for enforcement, a new source review procedure, and provisions for prohibiting new sources that will prevent "attainment" or "maintenance" of a NAAQS. The heart of the SIP" is the NSR plan, which is designed to ensure that all but the smallest of new sources will meet all applicable federal and state air quality regulations. The PSO rules focus prinarily on limiting $\mathrm{SO}_{2}$ and TSP emissions and apply to new sources that will affect a clean air area. A new source that affects a dirty air area is subject to a set of nonattainment regulations. The principal intent of these rules is to improve dir guslity in nonattainment areas by requiring more than compensating "emission of fsets" for any new source in such areas. For example, if a new source will contribute $x$ units of new pollution, a mor 8 than-compensuting reduction in emissions frum existing sourccs (c.o., $1.2 \mathrm{x}$ units) will he required to guarantee that progress is made toward the NAAQS for the criteria pollutant. This reduction in emissions from existing sources is required before any new source is permitted in a nonattainment area.

New source owners may have to obtain bolh a luonattainment permit and a PSD permit because a new souice may be subject to nonattainment regulations for one pollutant and to PSD rules for another pollutant, or even to both sets of rules for a given pollutant if the source's emissions affect both clean and dirty air areas. In such a case, the state 


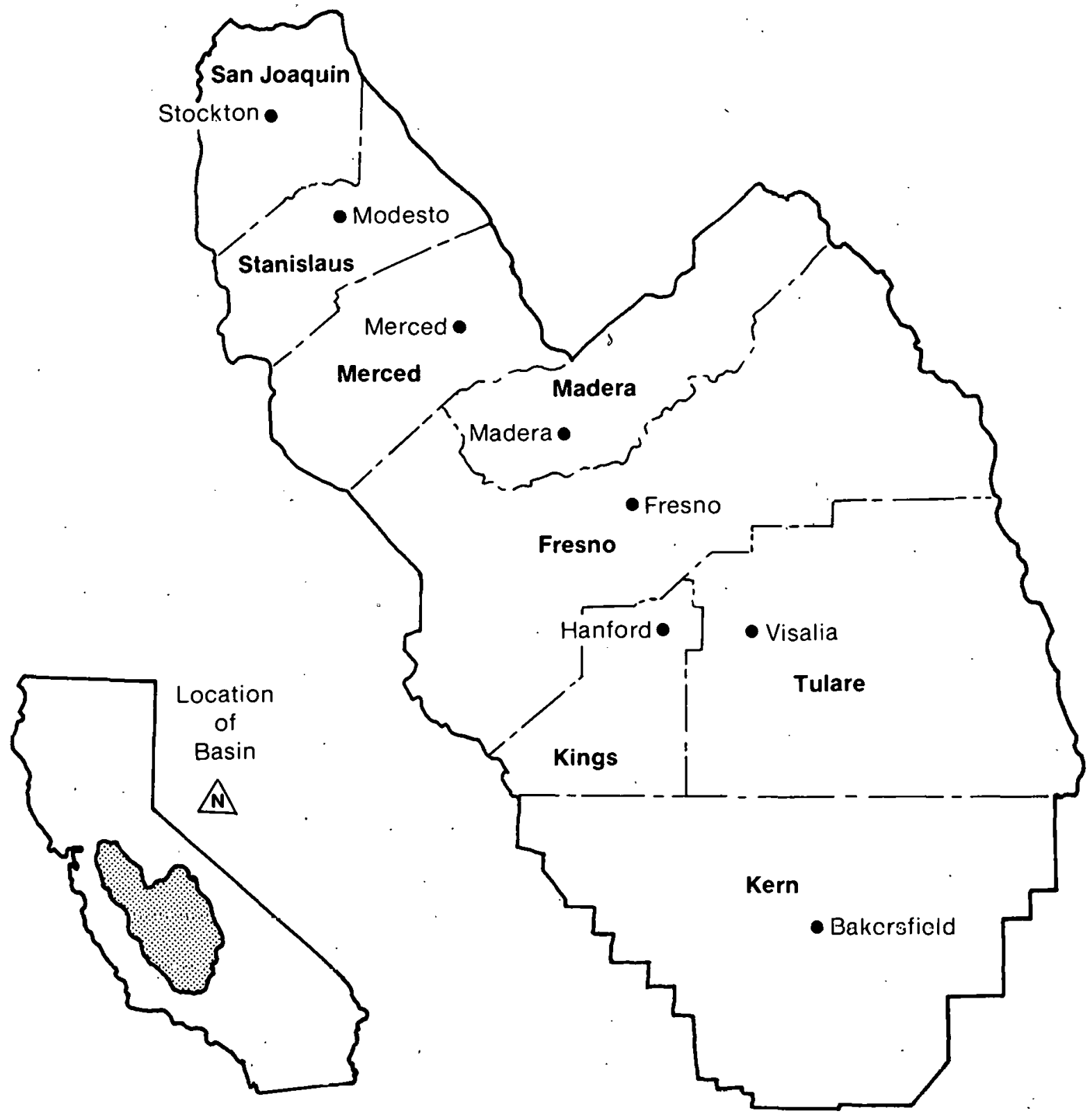

Figure 4-1. San Joaquin Valley Air Basin 
The definition of "potential emissions," as proposed by the EPA in the 5 September 1979 Federal Register, is the quantity of a pollutant emitted by any source operating at maximum capacity after the installation of air pollution control equipment. For example, potential emissions of $\mathrm{SO}_{2}$ from a 50 -MBtu/hr oil boiler with $96 \%$ efficient scrubbers are approximately 10 tons of $\mathrm{SO}_{2}$ per year (see Appendix B).* Thus, a boiler of this size is a minor source for $\mathrm{SO}_{2}$ since potential emissions are less than the 250-ton/yr limit, and it would not be subject to PST) rules for $\mathrm{SO}_{2}$ because only major sources are subject to the PSD regulations.

Multiple oil boilers run by a single company in an oil field can be treated as a single source, with an individual oil boiler called an "installation" and all the oil boilers in the field termed a "facility." Each installation may be a minor source, and the entire facility would become a major source subject to PSD rules when the aggregate emissions from all the installations exceeded the major source 100-ton or 250-ton per year limits. For oil boilers, the facility would become a major source of $\mathrm{SO}_{2}$ emissions when the equivalent of 10 or more $50 \mathrm{MBtu} / \mathrm{hr}$ boilers were placed in the same field and aggregate potential $\mathrm{SO}_{2}$ emissions exceeded 100 tons of $\mathrm{SO}_{2}$ per year for the facility.

The PSD regulations stipulate that no new major sources can be constructed unless many requirements are met, the most important of which are (1) that the major source must meet all enission limitations specified by the SIP and the Federal Standards of Performance for New Stationary Sources; and (2) that the major source must use the Best Available Control Technology (BACT), which defines on a case-by-case basis the maximum degree of reduction for a given pollutant as a function of energy, environmental, and economic variables.

Thus, in an attainment $A Q C R$, any EOR facility containing oil burner installations with an aggregate heat input greater than $500 \mathrm{MBtu} / \mathrm{hr}$ (hence, potential $\mathrm{SO}_{2}$ emissions greater than 100 tons per year) will be considered a major source of $\mathrm{SO}_{2}$ subject to the full range of $\mathrm{PSD}$ requirements. These PSD regulations will apply to all 500-MBtu oil burner facilities, including facilities used for primary EOR or solar hybrid activities.

In general, the PSD regulations are not a major constraint to the expansion of oil-fired EOR activities. Compliance with PSD requirements is not exceedingly difficult if the facility operator is willing to pay the high costs of compliance. The nonattainment regulations, however, may become serious constraints to oil-fired EOR expansion.

\subsubsection{Nonattainment (Offset) Regulations}

As with the PSD regulations, the distinction between major sources and minor sources is used for the nonattainment regulations. A major source is defined as any installation or facility with potential emissions greater than 100 tons per year of any criteria pollutant. The nonattainment regulations apply when the size of the facility exceeds. 500 $\mathrm{MBtu} / \mathrm{hr}$ of oil burning capacity and potential $\mathrm{SO}_{2}$ emissions exceed 100 tons/yr.

The first step in the nonattainment NSR process is an "emission review" and an "air quality review" to determine if each proposed major source meets all applicable.

* Since $\mathrm{SO}_{2}$ pollution is a major problem in the Kern River field, $\mathrm{SO}_{2}$ is the criteria pollutant used in this analysis to illustrate the NSR process. PSD or nonattainment regulations pertaining to other criteria pollutants may apply to larger or smaller facilities, depending upon specific conditions. 
emission requirements of the SIP and the Federal Standards of Performance for New Stationary Sources. If the source fails to meet all such requirements, the permit must be denied. In addition, all major sources must be reviewed to see if they will cause or contribute to a violation of an INAAQS; if so, the applicant must propose the use of an emission control technology involving the "Lowest Achievable Emission Rate" (LAER), the most stringent emission limitation which is achieved in practice.* In addition, emission reductions (offsets) from existing sources in the area of the proposed source are required such that there will be "reasonable progress toward attainment" of the applicable NAAQS. The EPA interprets reasonable progress toward attainment to mean that emission offsets must be greater than new emissions.

The reviewing authority may allow emission offsets that exceed the requirements of reasonable progress toward attainment to be "banked," that is, saved to provide offsets for a source seeking a permit in the future. By allowing the banking of offsets, the EPA, in effect, encourages the early cleanup of dirty sources. The SIP is free to govern the purchase, ownership, use, and sale of banked emission offsets (EPA 1979a). If an existing polluting facility wcrc to clean up its emissions, its owner might be allowed to bank them for future needs or to sell them to some other cornpany.

\subsubsection{The Getty Oil Company Case}

To appreciate the effect of environmental regulations on EOR, it is useful to describe the shutdown of Getty Oil Company's oil fired steam generators. In 1976, Getty received a permit from the EPA to install 62 oil burners (the equivalent of sixty 50-MBtu/hr units) in its Kern River field. The EPA issued the permit because at that time it was in charge of the nonattainment permitting process since Kern County had not yet had a SIP approved. The permit stated that, if the $\mathrm{SO}_{2} \mathrm{NAAQS}$ of 140 parts per billion (ppb) were exceeded, Getty had three options. First, it could shut down as many generators as needed to reduce fuel consumption by 9966 barrels of oil per day. This is equivalcnt to about sixty $50-\mathrm{MBtu} / \mathrm{hr}$ generators. Second, Getty could switch to low sulfur oil $\left(0.5 \%\right.$ versus $1.12 \%$ sulfur) to reduce $\mathrm{SO}_{2}$ emissions by 37.4 tons per day. Third, Getty could use emission control technology (scrubbers) that would reduce $\mathrm{SO}_{2}$ emissions by 37.4 tons per day.

On 26 December 1978, two of Getty's seven monitors showed $\mathrm{SO}_{2}$ readings of $171 \mathrm{ppb}$ and 174 ppb.** The previous high reading had been $102 \mathrm{ppb}$ in January 1977 . Getty officials attributed the violation to extremely adverse weather conditions in which cold, foggy, stagnant air prohibited normally effective natural dispersion. The next day Getty chose to shut down the equivalent of sixty $50-\mathrm{MBtu} / \mathrm{hr}$ generators to meet the permit conditions, arguing that the other options were too expensive in light of the federal controls on oil prices. Un that same day, ' 2 ' December 1978 , the $\mathrm{SO}_{2}$ reading was $90 \mathrm{ppb}$, far below the $\mathrm{SO}_{2}$ NAAQS.

*LAER is more restrictive than BACT. Whereas BAC'T is reviewed on a case-by-case basis and takes into account economic considerations, LAER is the most stringent emission control technology available by the given category of source, with only secondary consideration given to economic feasibility.

**Letter from M. L. Smith, Getty Oil Company, to Mr. Clyde B. Eller, Director, Enforcement Division, U.S. Environmental Protection Agency, San Francisco, 28 December 1978. Industry journals reported a reading of $179 \mathrm{ppb}$; see Anon. (1979f) and also the Getty press releases. 
'This incident implies that air quality regulations themselves are not the primary barrier to thermal EOK expansion in Kern County in the near term. One source estimates that Getty could add 3.5 times its current generating capacity to the Kern River field and still meet all LAER and offset requirements (Henwood 1977, p. 29). To comply with the permit conditions, however, Getty was forced either to make a significant capital investment for scrubbers (as much as $\$ 1.3$ million for 10 steam generators) or to use expensive, low sulfur fuel oil. Given the existing federal price ceilings on Getty's output of crude oil, company officials did not think it was economically sound to expand thermal EOR activities, or even to reopen their earlier EOR operations (Solomon 1979b; Anon. $1979 \mathrm{~g}){ }^{*}$ Thus, the effective constraint to expanded thermal EOR activities in the Getty episode appcals to be economic, not regulatory; i.e., the comparative economics of alternative means to meet air quality standards are more at issue than are the legal requirements. The latter can be met, the only question being the means. This same conclusion would apply to any hybrid solar EOR system.

\subsection{CONCLUSIONS}

Four major conclusions can be drawn from this analysis. First, it appears that an operator has an implied right to use the land surface for placement of solar collector arrays, proviced that there are no reasonable alternatives for producing oil. If a reasonable alteriative exists, negotiations between the operator and the surface owner probably would be necessary. In some cases, if the operator were willing to make large enough payments, the surface rights probably could be purchased, although such payments might increase the cost of the solar EOR project. Legal precedents in this area have not been established.

Second, oil field unitization presents no special problzins peculiar to solar EOR projects. If unitization were needed to conduct an EOR program, government and industry officials in California generally agree that the obstacles are not insurmountable despite California's relatively weak compulsory unitization statutes. This would be equally true for solar EOR projects.

Third, formation water appears to be available in sufficient quantities to allow some expansion of thermal EOR activities in California. The major water availability constraint to any form of steam EOR may be the potentially high cost of improving the quality of the formation water prior to its use in boilers.

*Recent press reports suggest that DOE and Getty officials have reached an agreement whereby Getty can receive higher prices for its oil and will therefore resume operàtions. Šee Parisi (1979, p. 1)-b). 
Finally, although the new air quality regulations in California, and especially in some oil field areas, are and will continue to be stringent,* permits for new oil-fired steam generators appear to be available if the operator is willing to pay the high cost of compliance. Two of the primary stimuli motivating solar EOR have been its environmentally benign characteristics as compared to fossil-fired generators and the possibility that new emission limitations for the latter might be impossible to attain. However, the second stimulus has not been verified. Permits are obtainable, given that the operators are willing to pay the costs of compliance and that emission offsets are available. Furthermore, solar EOR has not preempted the environmentally acceptable range of options: other technological alternatives to solar EOR allow fossil-fired steam generators to meet the air quality regulations. If solar EOR is to be a present solution to the problems of air quality compliance, the solar system must be economically competitive with a fossil fuel system equipped with BAC' or LAEK. If the solar system is not cost competitive, it will be difficult to justify its usc solely on the grounds of air quality benefits. This conclusion explicitly assumes the continued availability of emission offsets. However, in future years it may become increasingly difficult to obtain new permits as the supply of emission offsets dwindles (Lancaster 1979). Were this condition to occur, then air quality restrictions might yet force oil producers to adopt solar EOR or other nonpolluting systems as ways of maintaining production levels, air quality standards, and an acceptable rate of return on investment.

\footnotetext{
*On September 5, 1979, the EPA proposed to amend its regulations regarding the PSD and nonattainment NSR processes (EPA 1979b). The proposed changes would redefine such terms as "major source" and "potential to emit" as a result of an 18 June 1979 court decision (Alabama Power Company v. Costle, 13 ERC 1225), which overturned some of the existing EPA provisions. The proposed amendments, if adopted, could affect portions of this section's air quality analysis, although the conclusions should remain relatively unchanged.
} 


\section{SECTION 5.0}

\section{SYSTEM DESIGN REQUIREMENTS}

This section develops a set of system specifications for steam delivery, operating schedule, siting, and resource availability as the basis for comparing the costs and performance of various solar EOR systems. The specifications do not represent any specific EOR operation but are typical of a broad population of solar EOR projects. After a preliminary comparison of several solar thermal technologies that might be applicable to solar EOR, two of the most promising-the central receiver and parabolic trough-are examined in greater detail. Costs and performances for these two technologies are reported for various configurations and are compared with respect to each other and to conventional alternatives.

\subsection{SITE SELECTION AND LAND AVAILABILITY}

The great majority of thermal EOR projects are located in California, where reservoir characteristics and physical properties of heavy crude oil are most suited to steam stimulation. Typical steam supply systems operate through large steam generating centers connected by pipe networks to injection wells. Except for a few projects in Orange County and near Santa Barbara, most of these projects are in Kern County (near Bakersfield) and in Fresno County (near Coalinga). For this reason, this study defines the area of Kern County, near Bakersfield, as typical of the location in which a representative solar EOR system must operate. Base site characteristic: such as climate and topography were chosen as representative of this area. Figure 5-1 shows the Bakersfield area, the location of active EOR projects, and their respective oil fields.

Solar energy, of course, is diffuse and must be collected over an exiended area to meet the large energy demands of thermal enhanced oil recovery. Topography becomes a factor in solar system siting where unsuitable terrain presents installation problems that create extra cost and operating difficulties. The land nor th of Bakersfield is generally rugged, with rolling terrain of gradually increasing northward elevation. The topography, mostly knolls and depressions, is not particularly conducive to solar installations. Undeveloped areas adjacent to some of the active oil fields appear to have broader and flatter characteristics, perhaps more suitable for solar system siting. The terrain flattens out to the south of the Kern River where several oil fields (e.g., Miountain View and Edison) are located. As Fig. 5-2 shows, these sites would require extensive clearing and grading.

Placing solar systems within the active field area between wells seems unlikely for a large portion of the Kern River Field, where well spacing is on the order of 2.5 to 5 acres. The mass of piping, pumps, power lines, and access roads would make in-field siting extremely difficult. In fields to the north of Kern River, such as Mt. Poso, spacing between the wells is greater but the terrain is more rugged. Thermally connected collectors (such as troughs) would be difficult to install in such terrain. Optically transporting collectors, such as heliostats, might be more suitable, although positioning, adjustment, and maintenance might be expensive. 


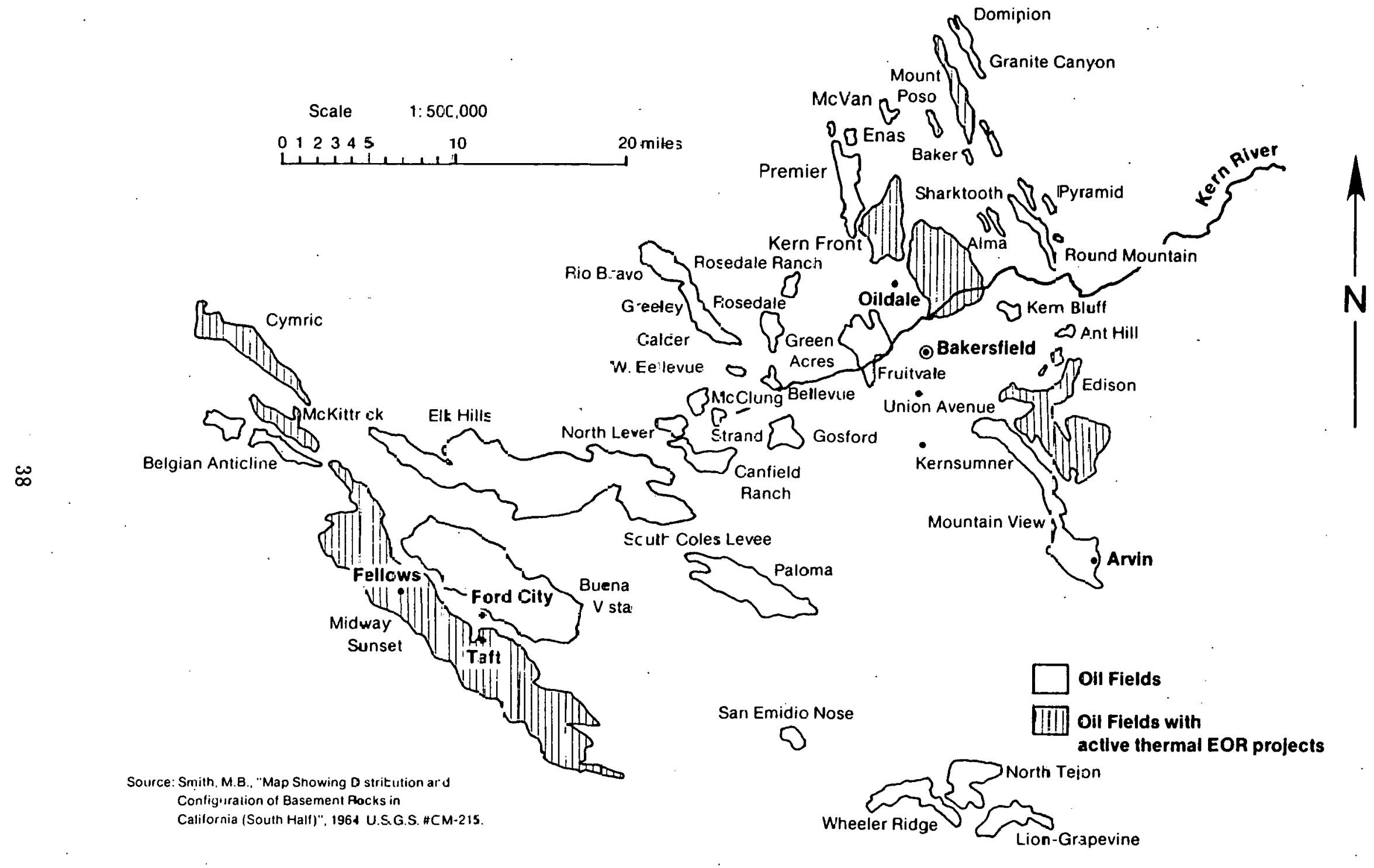

Figure 5-1. Bakersfield, California and Nearby Oil Fields 


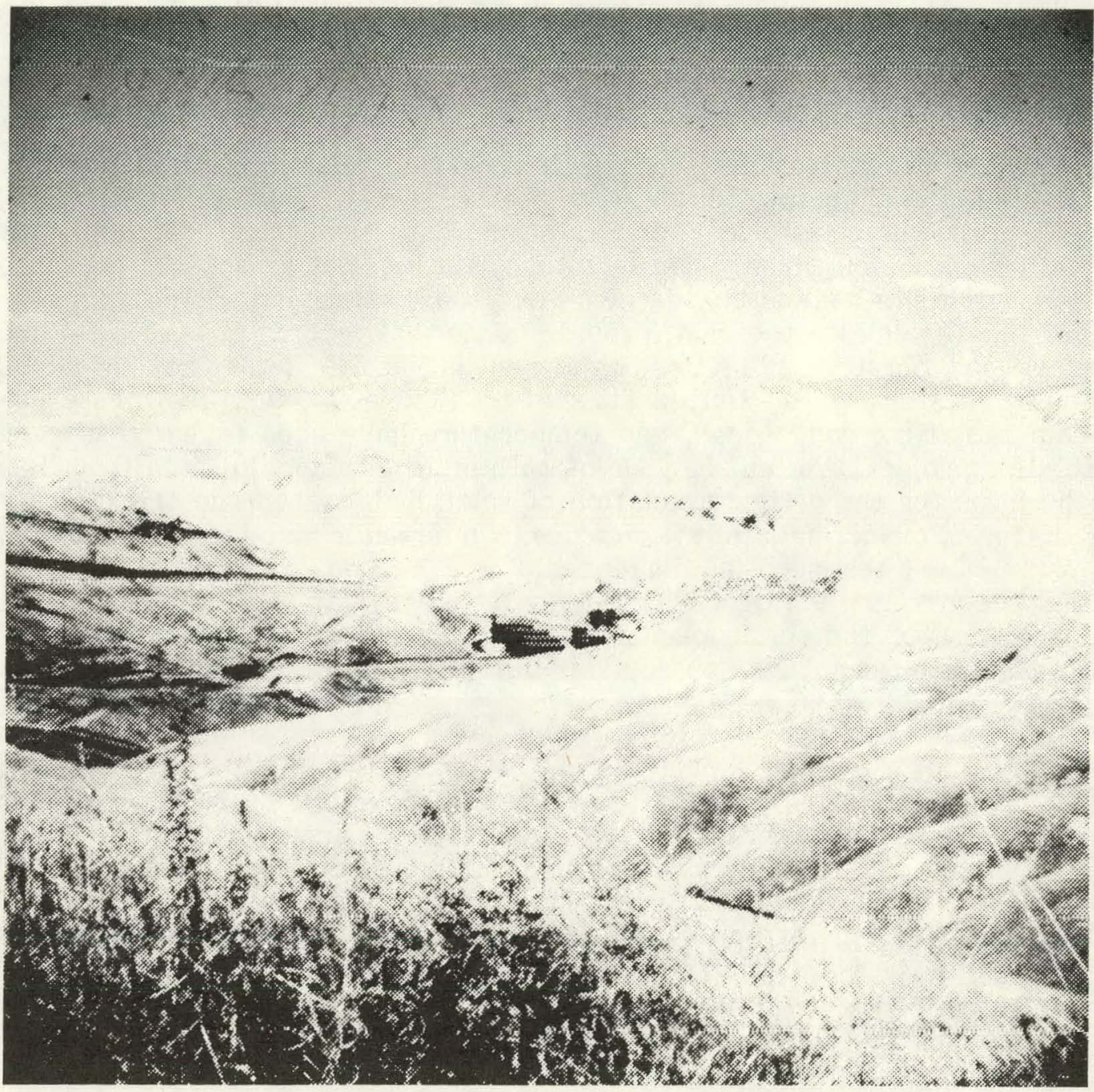

Figure 5-2. Typical Terrain North of Bakersfield, California 
Given the difficulty of siting solar systems among active wells, relatively flat areas adjacent to the active field would be needed and piping distances would be somewhat greater. Although the installation of solar EOR systems on land dedicated to that purpose is the most feasible option, future expansion of the oil field might be restricted or very expensive because of the need to relocate the solar EOR system.

\subsection{SOLAR INSOLATION}

Three meteorological stations near Bakersfield provide solar insolation data for system design and simulation. Fresno, 100 miles to the northwest, is one of 26 SOLMET sites in the United States where historical solar radiation data have been compiled. The available insolation data include only hourly total radiation, but reasonably accurate direct normal measurements may be derived by using standard correlations. China Lake/Inyokern, 74 miles to the east, provides historical records of both total and direct normal radiation. Barstow, 120 miles to the east, is the site of the first large-scale solar thermal power system in the United States (see Fig. 5-3). Detailed measurements of direct beam radiation, wind speed, and temperature have been taken to support design efforts for this project. An entire year of 15-minute incremental data from Barstow is used as the basis for the design simulation of solar EOR systems in this study. System behavior, in terms of incremental efficiencies, can be determined using Barstow data and applied to nearby sites such as Bakersfield and Fresno. Table 5-1 shows the climatological records available for Bakersfield from Berdahl (1977). Estimates of solar resource availability from interpolation between Fresno and Inyokern also are shown. These data establish the solar resource availability used in this study.

SERI analysts have developed a detailed solar thermal system simulation code known as BALDR-1 for analyzing small solar thermal electric power systems.* The code can compare many variations of generic solar thermal collector systems by simulating an energy balance of heat losses at 15-minute intervals for an entire year. The output of BALDR-1 has been used to generate monthly and annual collector subsystem field efficiencies for the Barstow location. These results are then applied to the insolation data shown in Table 5-1 to estimate collector-subsystem delivered energy values for Bakersfield. While the translation of subsystem efficiencies is rigorously correct only for sites at the same latitude, the error in translation of efficiencies between Barstow and Bakersfield (which differ in latitude by 0.5 degree) is not significant in this analysis.

\subsection{OPERATING REQUIREMENTS}

\subsubsection{Steam Conditions}

For steamdrive EOR, the steam conditions (pressure, temperature, and quality) at the surface of the injection well depend upon a number of parameters including well depth and formation fracturing pressure. Certain design rules-of-thumb apply, however. For continuous injection, the steam pressure should not exceed 2500 psi. Normally, surface steam pressure equal to 0.75 to 1.0 psi per foot of well depth is required. Well depth in most of the Kern River oil field (which is largely steamflooded) averages $900 \mathrm{ft}$, suggesting average surface steam pressures of 675 psi to 900 psi, although some operators have

*BALDR-1 is described in greater detail in Thornton et al. (1979). 


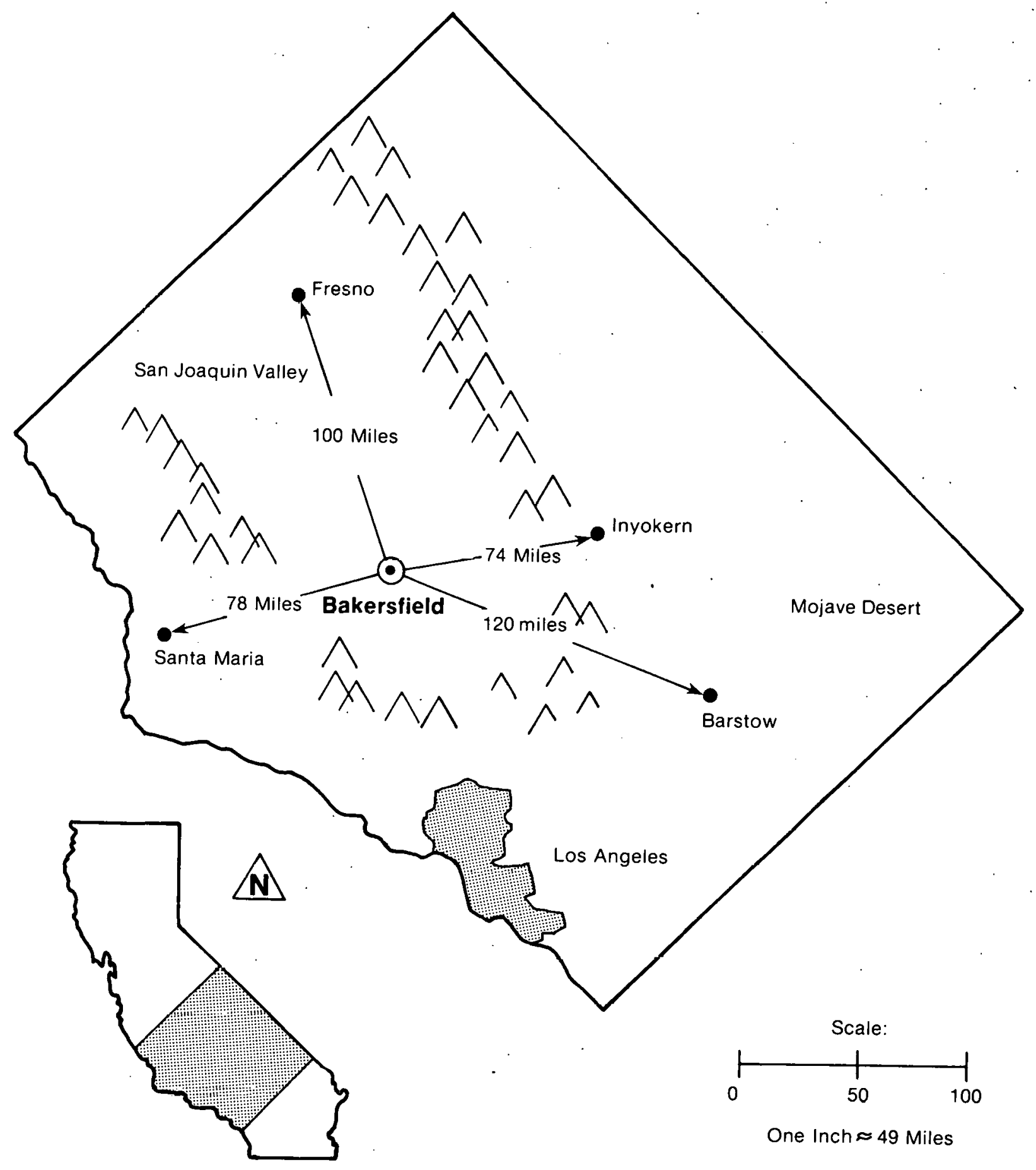

Figure 5-3. Location of Meteorological Stations Near Bakersfield, California 
Table 5-1. FAKERSFIELD METEOROLOGICAL DATA ${ }^{a}$

Latitude: $35.42^{\mathrm{c}} \quad$ Lonz̧itude: $119.05^{\circ} \quad$ Elevation: $4 \therefore 5^{\prime}$

\begin{tabular}{|c|c|c|c|c|c|c|}
\hline Month & $\begin{array}{l}\text { Avg. Daily } \\
\text { Direct iormal } \\
\text { Radia:ion } \\
\left(10^{3} \mathrm{Bzu} / \mathrm{ft}^{2}\right)\end{array}$ & $\begin{array}{c}\text { Montly } \\
\text { Direct Nor nal } \\
\text { Radiation } \\
\left(10^{3} \mathrm{Btu} / \mathrm{ft}^{2}\right.\end{array}$ & $\begin{array}{c}\text { Average } \\
\text { Temperature } \\
\left({ }^{\circ} \mathrm{F}\right)\end{array}$ & $\begin{array}{c}\text { Freeze } \\
\text { Days }\end{array}$ & $\begin{array}{l}\text { Precipitation } \\
\text { (in) }\end{array}$ & $\begin{array}{c}\text { Relative } \\
\text { Humidity } \\
10 \text { a.m. } \\
\text { (\%) }\end{array}$ \\
\hline Jan & $1 . \bar{\partial} 9$ & 40 & 47.5 & 5 & 6.96 & 75 \\
\hline Feb & 1.50 & 42 & 52.4 & 1 & 1.03 & 65 \\
\hline Mar & 2.03 & 63 & 56.6 & $1 / 2$ & 0.83 & -54 \\
\hline Apr & 2.57 & 77 & 62.7 & 0 & 0.85 & 45 \\
\hline May & 2.68 & 83 & 69.8 & 0 & 0.19 & 37 \\
\hline Jun & 2.82 & 84.5 & 76.9 & 0 & 0.06 & 35 \\
\hline Jul & 2.74 & 85 & 83.9 & 0 & 0.02 & 32 \\
\hline Aug & 2.52 & 78 & 81.6 & 0 & 0.01 & 34 \\
\hline Sep & 2.27 & 68 & 76.6 & 0 & 0.08 & 39 \\
\hline Oct & 1.37 & 58 & 66.9 & $1 / 2$ & 0.26 & 46 \\
\hline Nov & 1.33 & 40 & 56.0 & $1 / 2$ & 0.69 & 65 \\
\hline Dec & 1.13 & 35 & 47.9 & 5 & 0.74 & 77 \\
\hline Annual & 2.06 & 753.5 & 64.9 & 12 & 5.72 & 50 \\
\hline
\end{tabular}

${ }^{a_{\text {Source: }}}$ NWS clinatic survey and interpolition of DN radiation between Fresno anc Inyokern. Comments: Drier than Fresno, generally warner.

${ }^{b}$ Direct normal radiation values are determined by interpolating between Fresno and Inyokern. These values are estimates only and are subject to revision as more accurate data are obtained. 
said that wellhead pressure is only 400 psi in many of their injector wells.* Partially "wet" (less than 100\% quality) steam is always preferred; in addition to reducing water tube scale deposition, "wet" steam allows more constant temperature control. Eighty percent steam is adopted for this study.

One set of steam delivery conditions will be assumed throughout this analysis. The injection well delivery requirements are $80 \%$ steam at $850 \mathrm{psi}\left(525^{\circ} \mathrm{F}\right)$ at the most distant injection well. The calculated steam pressure drops are $20 \mathrm{psi}$ in the main steam distribution line and $130 \mathrm{psi}$ in the 3 -in. injector feed line to the most distant well $(6,000 \mathrm{ft})$. Therefore, steam must be generated at 1,000 psi and $80 \%$ quality (no significant drop in quality occurs over the lines) at the solar steam generator. To produce steam at 1000 psi, 80\% quality via an oil-fired steam generator, inlet and outlet temperatures to the steam generator from the collector field are defined by the maximum feasible operating temperature for the heat transfer fluid and the minimum feasible temperature difference for which the steam generator should be designed. Inlet and outlet temperatures of $620^{\circ} \mathrm{F}$ and $510^{\circ} \mathrm{F}$ (respectively) were aclopted for this study.

\subsubsection{Injection Scheduling}

Anywhere from 1 to 15 barrels of steam may be required per day per foot of oil zone cepth in a typical injection well.** For successful steaning oil zone depths must be at least $30 \mathrm{ft}$. Typical Kern River oil zone depths are 100 to $150 \mathrm{ft}$. Therefore, 100 to $2,250 \mathrm{bbl}$ steam/day per well might be required. A typical well could require about $634 \mathrm{bbls} / \mathrm{steam}$ per day, equivalent to about $10 \mathrm{liBBtu} / \mathrm{hr}$ or $3 \mathrm{iMV}$. As noted in Sec. 2.0 even intermittent steam injection, or steam soak, requires that steam be injected continuously-for periods of one week or more. Therefore, the required injection schedule for solar EOR design requirements is essentially continuous. Lower injection rates normaily are used for steam flood techniques and annual utilization, of course, is higher.

\subsubsection{Steam Generating Capacity}

The key issue in solar system sizing for EOR relates to the properties of the oil reservoir and its ability to retain and utilize heat supplied intermittently. If it is possible to maintain oil prodiuction by supplying stcam at a high rate only during daylight hours (that is, supplying no steam during the remainder of the day), then stand-alone, minimal storage, solar EOR systems are feasible. The potential steam supply schedule and the amount of energy required to replace one $50-3 t u / h r$ steam generator with only daytime injection is shown in Fig. 5-4. If continuous, 24-hr steam injection were required, two other options for solar system design must be considered. The first is a solar system sized to provide supplemental fuel savings to a conventional EOR steam senerator(s), i.e., a solar retrofit hybrid EOR system. In this case, the solar system is sized to provide the approximate inaximum rated output $(50-\mathrm{MiBtu} / \mathrm{hr})$ on a certain "peak" day during the year. Energy to

*Society of Petroleum Engineering of AIME, Enhanced Oil Field Reports, Vol. 1-3 (19771979); cited in Bergeron (1979, p. 17).

** One barrel of steam is defined as me barrel of liquid water, or 42 gal, cumpletely evaporated into saturated steam. One barrel of water at room temperature weighs approximately $350.5 \mathrm{lb}$. Approximately $1000 \mathrm{Btu}$ are required to vaporize $\mathrm{l} \mathrm{lb}$ of water to yield steam at about $500^{\circ} \mathrm{F}$. Therefore, the latent energy content of a barrel of steam is $350.5 \times 1000=350 ; 500$ Btu. 


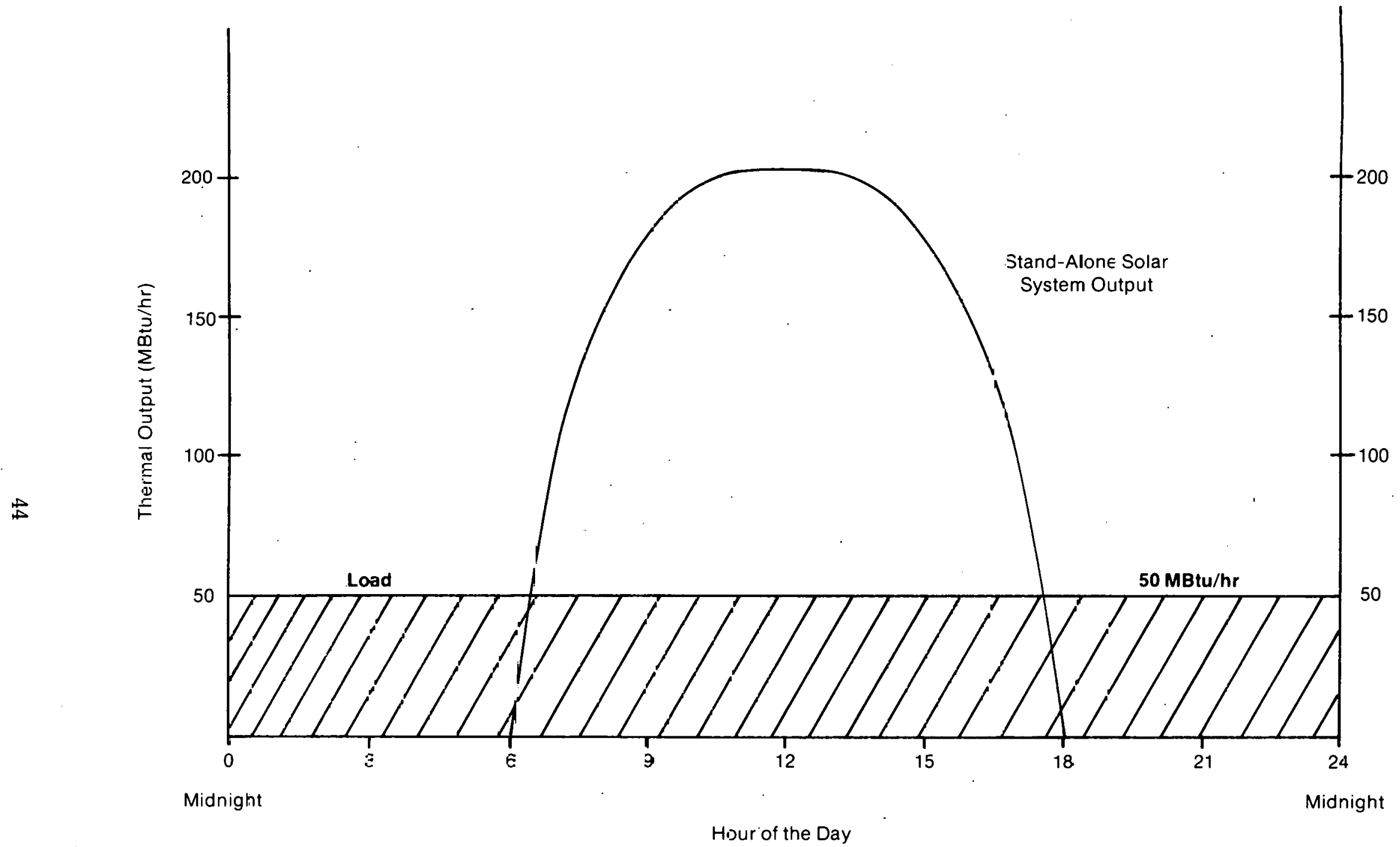

Figure 5-4. Daily Load and Solar Steam Supply Profiles for Solar Stand-Alone Systems

Supplies $103 \%$ of Output of $50 \mathrm{mmBtu} / \mathrm{hr}$ Generator on an Average Annual Basis 
generate steam for periods of intermittent or low insolation, or for sunrise and sunset conditions, would be provided through small amounts of solar storage and through controlled incremental firing of fossil-fueled EOR generators. Steam injection at night or during periods of extended cloudiness would be provided by fossil-fueled backup. Figure 5-5 shows the steam supply profile of a solar retrofit hybrid steam-drive EOR system. Note that approximately one-third of the required output is supplied by solar energy. The second option provides a relatively large amount of dedicated solar system storage to obtain an annual solar system capacity factor of approximately $90 \%$. Such a system would provide continuous injection from the solar system alone, barring periods of low insolation of more than $24 \mathrm{hr}$. The potential steam supply load curve of such a system is shown in Fig. 5-6.

The feasibility of intermittent or diurnal steam injection (Fig. 5-4) has been the subject of serious dispute. SERI's interviews suggested that most oil field operators do not think that diurnal, intermittent steam injection would be satisfactory for EOR in steamflood or steamdrive projects. These operators cite excessive down-hole heat losses and thermal fatigue and shock in well casings as primary problems in adopting such a schedule. Other sources state that the radical changes in temperature might cause excessive sanding in the well bore. Some operators, however, found no reason to suspect that such an injection schedule would not be satisfactory; that because 24-hr continuous injection has been the rule does not mean that it is a necessity. Calculations and experiments by experienced petroleum engineers-not solar system design specialists-are needed to resolve this issue.*

In the absence of a definite judgment on the feasibility of intermittent (day only) solar steam injection, this study assumes that 24-hr continuous injection will be required. Costs of delivered energy for the solar system will not differ significantly between the stand-alone solar design (Fig. 5-4) and the solar retrofit hybrid design (Fig. 5-5), so that the essentials of the comparison of these two systems are not lost. In either case, the design of the solar system is essentially the same, inasmuch as both systems are designed with only buffer storage capacities.

Most conventional steam generating units seen during a site visit to the Bakersfield oil field were of 50-MBtu/hr capacity and were "ganged," or clustered, in groups of seven to ten. Because the proposed solar steam system would introduce steam into the existing steam distribution network, comparisons with conventional EOR systems are most convenient when the solar EOR system is sized to provide a steam output capacity analogous to a typical conventional steam generating unit (50-MBtu/hr). Therefore, the following solar system EOR designs are standardized for rated steam generating capacities equivalent to a $50-\mathrm{MBtu} / \mathrm{hr}$ unit, although there is no reason to assume that solar EOR systems would be limited to that generating capacity.

Because of the variable nature of daily solar system output, there are several ways of defining a rated capacity of $50-\mathrm{MBtu} / \mathrm{hr}$, none of which has been generally adopted as a

*Bergeron (1979, p. 15) suggests that intermittent injection of steam (i.e., a pure solarpowered system) would be sufficient but also concludes that further research is necessary to resolve the technical points of this question; specifically, do oil production rates require continuous steam injection or is intermittent injection adequate? MeCann ct al. (1979) cite the results of an oil field simulation that suggest that diurnal steam injection will extract the same amount of petroleum from a field as continuous injection but will take over twice as long (e.g., $85 \%$ of the oil in place in 12 vs. 5 years for continuous steam injection). 


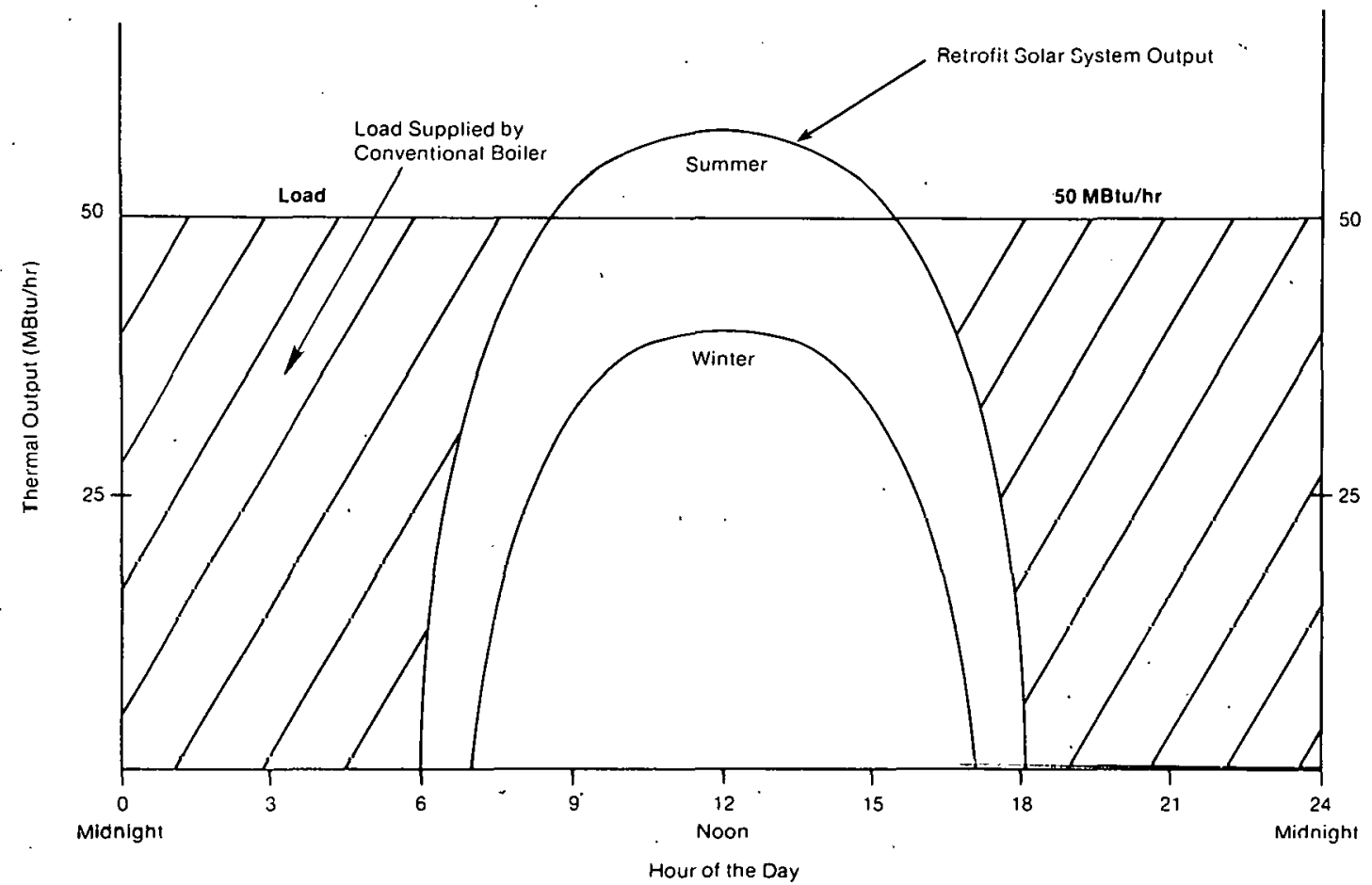

Figure 5-5. Daily Load and Solar System Supply Profiles for Hybrid Systems Supplies $33 \%$ of Output of $50 \mathrm{MBtu} / \mathrm{hr}$ Generator on an Average Annual Basis

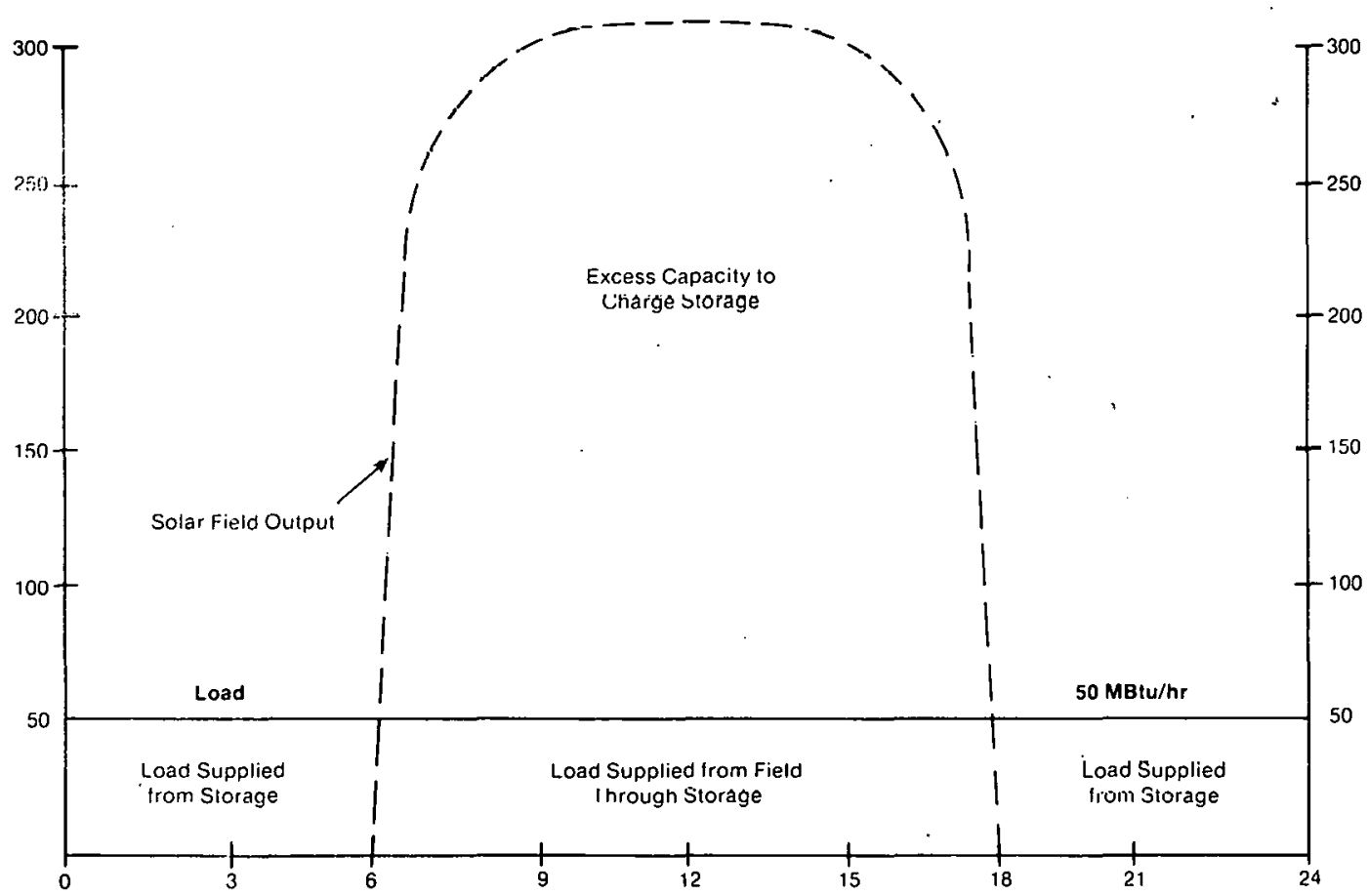

Figure 5-6. Daily Load and Solar Steam Supply Profiles for Solar Systems with Dedicated Storage 
standard among solar engineers. For example, if a rating of $50-\mathrm{MBtu} / \mathrm{hr}$ is taken as a peak rating, then the solar system must be sized to deliver exactly $50-\mathrm{MBtu} / \mathrm{hr}$ at the instant the product of insolation and field efficiency is maximized. It follows that at all other times during the year the system will deliver less than $50-\mathrm{MBtu} / \mathrm{hr}$. As an alternative, the solar system may be sized to deliver an average output equivalent to a conventional 50-MBtu/hr boiler over some specified period. In this report, the solar hybrid systems have been designed to provide a total daily output ( $12 \mathrm{hr}$ ) equivalent to the normal firing of one 50-MBtu/hr boiler in June (the peak insolation month). Since conventional boilers are typically operated at $90 \%$ of their rated capacity, the total daily output of the conventional system is:

$$
0.90 \times 12 \mathrm{hr} \times 50-\mathrm{MBtu} / \mathrm{hr}=540 \mathrm{MBtu} \text {. }
$$

A solar system sized to provide 540-MBtu/day in June will provide in excess of 50$\mathrm{MBtu} / \mathrm{hr}$ at many tirnes during the year (see Fig. 5-5). Controlled steam flow and boiler firing would be required to balance solar output with conventional capacity.

The relative effects of the different sizing standards are especially important in the calculated annual capacity factor of the system. This factor, which represents the fraction of the annual conventional system steam output potentially displaced by the solar EOR system, is directly proportional to the total annual solar system energy output. A solar EOR system sized to provide peak output of 50-MBtu/hr will have a lower annual capacity factor than one sized to provide 540-MBtu/day during June. A solar system sized to provide the equivalent annual output of a conventional $50-\mathrm{MBtu} / \mathrm{hr}$ boiler, or 394,200-MBtu/yr (see Fig. 5-4), would have an annual capacity factor of $100 \%$, by definition.

\subsubsection{Summary of Specifications}

The design specifications and ground rules adopted for this report have been selected to represent a typical operating field utilizing steamdrive techniques in accordance with solar insolation typical of the Bakersfield area. The availability of a relatively flat site, unencumbered by oil wells, piping, power lines, or access roads, is assumed. Steam is generated at $80 \%$ quality, $1000 \mathrm{psi}$, and $545^{\circ} \mathrm{F}$. The system is a hybrid, that is, solarpowered during daylight hours and fossil-fired during the remainder of the day; this decision is largely based on the uncertainty of reservoir responses to either large steam injection rates (as in a stand-alone solar system) or the intermittent injection of steam (as with diurnal injection). In view of the widespread use of conventional boilers rated at $50-\mathrm{MBtu} / \mathrm{hr}$, the solar system is sized to displace the average daily output of a 50 $\mathrm{MBtu} / \mathrm{hr}$ boiler on a June day (540-MBtu/day). The study assumes the existence of conventional boilers and. a steam distribution system to which the solar EOR system can be connected. Again, these specifications do not represent any particular existing solar EOR design but apply to a broad class of operating projects in which solar energy might be used.

\subsection{REVIEW OF ALTERNATIVE TECHNOLOGIES}

At least six generic collector concepts for generating high pressure steam for steamdrive EOR can be identified. These systems can generate and deliver heat at required temperatures (approximately $500^{\circ} \mathrm{F}$ to $550^{\circ} \mathrm{F}$ ), although their performances and costs vary significantly. Projections of performance and cost may have even greater variances because of technological uncertainties. Since it is not possible to analyze in detail all of these solar thermal technologies, certain concepts must be eliminated in a first broad analysis. These concepts are defined in the manner adopted in the SERI Small Power 
System Study ('Thornton et al. 1979) and are listed in Table 5-2. Collector field subsystem efficiencies, transport efficiencies, and steam generation efficiencies are shown for each system in Table 5-3. Table 5-3 also shows the systems' respective efficiencies estimated with 1985 collector costs and a calculated "cost effectiveness index" for each system. The "cost effectiveness index" is the collector unit cost per unit area (column e) divided by the annual total efficiency (column d). A low index value is a first order approximation of the more cost-effective systems. Two systems, PFCR and LFDR-TC, have cost-effectiveness indices much lower than the others. As a result, this report will consider only the central receiver and parabolic trough concepts in detail. Using the performance information from BALDR-1 simulations, the detailed analysis of two central receiver and two parabolic trough EOR systems are described below. Annual performance estimates, daily and seasonal output curves, estimated capital cost, and operating and maintenance expenses are derived for each system to project annualized or levelized costs. Detailed design and engineering of the various systems has not been done.

Two technology design scenarios are used for both the parabolic trough and the central receiver systems*: the advanced state of the art (i.e., what these systems are projected to achieved in terms of system efficiencies and unit costs within 4-5 years) and system goals (i.e., projected system efficiencies and costs within the next 10-15 years). Specifically, a net annual system efficiency of 0.43 is ascribed to the advanced state-of-the-art parabolic trough (designated system A), which assumes a high performance parabolic trough by 1985; the projected net annual average system efficiency for the goal designed parabolic trough (designated system $B$ ) is 0.51 . The two central receiver designs represent the projected performance for the first generation (1983) heliostat/receiver technology (designated system $C$; annual efficiency of 0.55 ) and the performance goals for second or third generation (1990) central receiver technology (designated system D; annual efficiency of 0.53 ). Component specifications for current, advanced state-of-theart, and goals technology for solar energy systems are listed in 'l'able b-4.

\subsection{PHYSICAL AND ECONOMIC CHARAC'TERISIICS}

The physical characteristics of the representative solar EOR systems are listed in Table 5-5. The systems were designed, or "sized," to deliver a full daytime equivalent of a $50-\mathrm{MBtu} / \mathrm{hr}$ steam generator. Because such generators normally are operated at only $90 \%$ capacity and active daylight operating time for the solar system in June is approximately $12 \mathrm{hr}$, the systems are sized to deliver an integrated daily output of $540-M B t u / d a y$ (row 6). This is the baseline against which all systems in this report should be measured and compared.**

*These design scenarios are extracted from and documented in Thornton et al. (1979).

**As noted earlier, several standards may be applied in sizing solar EOR systems to deliver the "equivalent" of a 50-MBtu/hr capacity conventional boiler. The choice of any given benchmark will make a difference in system collector field size and hence the initial system cost, but the relative position and the absolute value of delivered energy costs will not be significantly affected. In this study, the solar hybrid system is sized to provide an average daily output of $540 \mathrm{MBtu}$ in June. If, instead, the system were sized to provide an absolute peak thermal capacity of $50 \mathrm{MBtu} / \mathrm{hr}$, the following calculations would hold:

1. At peak available collector field output capacities of $198 \mathrm{Btu} / \mathrm{hr} / \mathrm{ft}^{2}$ for System B and $240 \mathrm{Btu} / \mathrm{hr} / \mathrm{ft}^{2}$ for System D, the collector areas required for Systems B and D 
Table 5-2. SIX GENERIC SOLAR THERMAL SYSTEMS FOR ENHANCED OIL RECOVERY

\begin{tabular}{|c|c|c|c|}
\hline Collector & Receiver & Symbol $^{a}$ & Description \\
\hline \multirow[t]{3}{*}{ Two-axis } & $\begin{array}{l}\text { Centralized } \\
\text { tracking }\end{array}$ & PFCR & $\begin{array}{l}\text { Concentrating collector field consisting } \\
\text { of two-axis tracking heliostats, } \\
\text { arranged north of a cavity receiver atop } \\
\text { a free-standing steel tower. Violten } \\
\text { salt to steam generator. }\end{array}$ \\
\hline & Distributed & PF DR & $\begin{array}{l}\text { Concentrating collector field consisting } \\
\text { of paraboloidal dishes which track on } \\
\text { two axes, heat pipe receiver with trans- } \\
\text { fer to steam generator using Hitec, } \\
\text { Syltherm or } \mathrm{T}-66 \text {. }\end{array}$ \\
\hline & & FMDF & $\begin{array}{l}\text { Large stationary hemispherical bowl as } \\
\text { a concentrator and "roaming" receiver } \\
\text { for distributed focus. ivolten salt used } \\
\text { in receiver and transferred to steam } \\
\text { generator. }\end{array}$ \\
\hline \multirow[t]{4}{*}{ One-axis } & $\begin{array}{l}\text { Centralized } \\
\text { tracking }\end{array}$ & LFCR & $\begin{array}{l}\text { Concentrating collector field of one- } \\
\text { axis (E-W) tracking heliostats and } \\
\text { molten salt linear cavity receiver. } \\
\text { facing north. Receiver supported on } \\
\text { guyed steel tower; steam generator } \\
\text { used. }\end{array}$ \\
\hline & & LFDR-TC & $\begin{array}{l}\text { Parabolic trough collector field using T- } \\
66 \text { (or equivalent) as heat transfer fluid } \\
\text { in selective surface coated and glass } \\
\text { jacketed receiver tubes. Steam }\end{array}$ \\
\hline & Distributed & · & $\begin{array}{l}\text { produced in a steam generator. } \\
\text { Tracking about } \mathrm{N}-\mathrm{S} \text { axis. }\end{array}$ \\
\hline & ' & LFDR-TR & $\begin{array}{l}\text { Stationary, segmented trough } \\
\text { concentrators on a tilted E-W axis with } \\
\text { tracking receiver tube having secondary } \\
\text { concentration. Heat transfer fluid ( T- } \\
\text { 66) to steam generator. }\end{array}$ \\
\hline
\end{tabular}

$\begin{array}{ll}\text { a PFCR: } & \text { Point-Focus Central Receiver } \\ \text { PFDR: } & \text { Point-Focus Distributed Receiver } \\ \text { FMDR: } & \text { Fixed Mirror, Distributed Focus } \\ \text { LFCR: } & \text { Line-Focus Central Receiver } \\ \text { LFDR-TC: } & \text { Line-Focus Distributed Receiver (Tracking Collector) } \\ \text { LFDR-TR: } & \text { Line-Focus Distributed Receiver (Tracking Receiver) }\end{array}$


Table 5-3. COMPAFISON OF GENERIC SOLAR EOR SYSTEMS

\begin{tabular}{|c|c|c|c|c|c|c|}
\hline \multirow[b]{2}{*}{ System } & \multicolumn{4}{|c|}{ Annual Ifficiency } & \multirow[b]{2}{*}{$\begin{array}{c}\text { (e! } \\
\text { Collector } \\
\text { Cost* } \\
\left(\$ / \mathbf{f t}^{2}\right) * *\end{array}$} & \multirow[b]{2}{*}{$\begin{array}{c}\text { (f) } \\
\text { Cost } \\
\text { Effectiveness } \\
\text { Index }\end{array}$} \\
\hline & $\begin{array}{l}\text { (a) } \\
\text { Collector } \\
\text { Field }\end{array}$ & Transport & $\begin{array}{c}\text { (c) } \\
\text { Steæm } \\
\text { Generation }\end{array}$ & Total & & \\
\hline PFCR & 0.58 & 0.99 & 0.38 & 0.56 & 8.50 & 15.2 \\
\hline PFDR & 0.63 & 0.90 & 0.78 & 0.56 & 10.80 & 19.3 \\
\hline LFCR & 0.44 . & 0.96 & 0.38 & 0.41 & 14.00 & 34.1 \\
\hline FMDF & 0.44 & 0.98 & 0.97 & 0.42 & $12 . \mathrm{G0}$ & 28.6 \\
\hline IF DR-TC & $0.5 I^{\prime}$ & 0.97 & 0.97 & 0.48 & 7.90 & 16.5 \\
\hline IFDR-TR & 0.38 & 0.97 & 0.97 & 0.36 & 7.90 & 21.9 \\
\hline
\end{tabular}

* Collector zost is the unit cost of the conentrator and receiver as estimated from data supplied in Table A-1 of Thornton et al. (1979). Receiver or colleetor moanting structure costs, pipiag costs, and cost of steam generators are not included. While these additional costs are significant, the major portions of direct field costs in solar thermal systems lie in collector eosts. Herce, these costs can be taken as representative of the relative total direct field eosts of these systems. Also note that costs assigned in this table may not agree witr later estimates of costs ior PFCR and LFDR-TC systems in this analysis. This comparisan is made cnly to derive a relatively simple, preliminary ranking tc identify the most promising collector concepts for EOR.

**All costs listed jere and throughout the report are in constant 1979 dollars, unless otherwise noted. 
Table 5-4. SPECIFICATIONS FOR SOLAR COMPONENTS

\begin{tabular}{|c|c|c|c|c|c|c|}
\hline & \multicolumn{3}{|c|}{ Parabolic Trough } & \multicolumn{3}{|c|}{ Central Receiver } \\
\hline & & $\begin{array}{l}\text { Advanced } \\
\text { State of the }\end{array}$ & & & $\begin{array}{l}\text { Advanced } \\
\text { State of the }\end{array}$ & \\
\hline & Current & Art & Goals & Current & Art & Goals \\
\hline \multicolumn{7}{|l|}{ Collector cost } \\
\hline Collector reflectivity & 0.83 & 0.86 & 0.95 & 0.91 & 0.91 & 0.95 \\
\hline \multicolumn{7}{|l|}{$\begin{array}{l}\text { Receiver cost } \\
\text { installed }\left(\$ / f t^{2}\right)\end{array}$} \\
\hline Receiver absorptivity & 0.94 & 0.94 & 0.94 & 0.94 & 0.95 & 0.97 \\
\hline Receiver transmissivity & 0.91 & 0.91 & 0.96 & - & - & - \\
\hline Receiver type & Glass Jaeket & Glass Jacket & Evacuated & Cavity & Cavity & Cavity \\
\hline
\end{tabular}

${ }^{a}$ Exclusive of drive, controls, and foundation. 
Table 5-5. PERFORMANCE AND PHYSICAL CHARACTERISTICS OF SOLAR EOR SYSTEMS

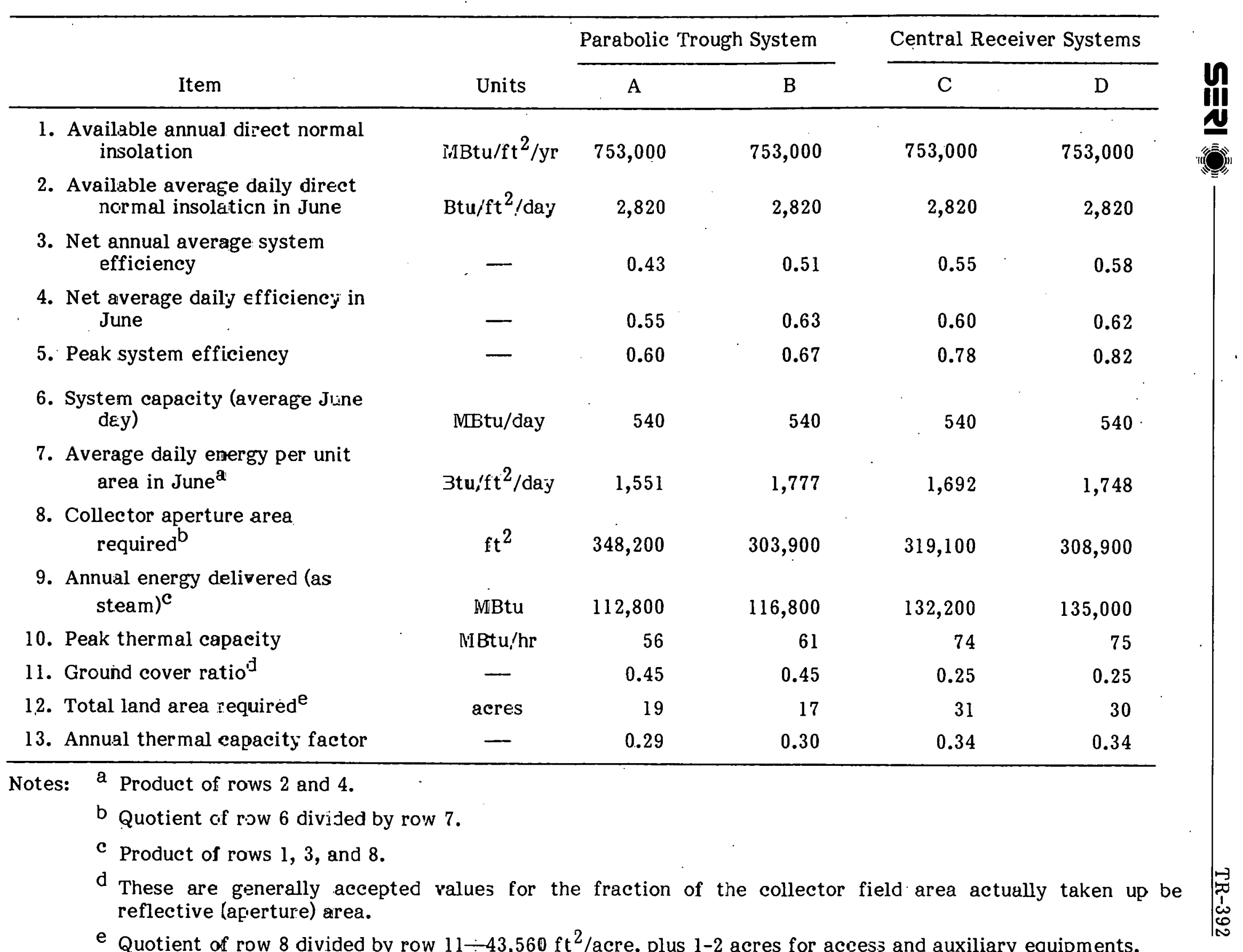


Three additional rows should be noted in Table 5-5. Row 3, the "Net Annual Average System Efficiency," reflects the advanced state of the art (systems A and C) and goals (systems B and D) for these technologies; they should not be mistaken for efficiencies presently available. Row 10, "Peak Thermal Capacity," represents the maximum power output (expressed in $\mathrm{MBtu} / \mathrm{hr}$ ) that any of the systems can deliver at a given time; it occurs when the product of the instantaneous direct normal insolation and instantaneous net efficiency is maximized (normally in June or July). Although the systems vary by as much as a third in their respective peak thermal capacities, it should be remembered that the integral of the delivered energy output over the course of the day (again, see row 6) is the same. The optical properties of the collectors are such that the systems produce different peak thermal capacities while producing the same amount of energy over the course of the day. Finally, the annual thermal capacity factor (row 13) is defined as the annual energy delivered (row 9) divided by the potential annual energy output of a conventional $50-\mathrm{MBtu} / \mathrm{hr}$ boiler (i.e., $50-\mathrm{MBtu} / \mathrm{hr} \times 0.90 \mathrm{X} 8760 \mathrm{hr} / \mathrm{yr}$ ). It. represents, then, the effective fraction of steam production of one $50-\mathrm{MB}$ Btu/hr boiler that would be displaced by operating the solar energy steam EOR system for an entire year. A profile of average monthly steam production for solar EOR systems during a typical year is shown in Fig. 5-7.

Table 5-6 displays the comparative system costs of the two parabolic trough and two central receiver systems. The cost estimates are based upon the collector area, energy delivery calculations from Table 5-5 (rows 8 and 9, respectively), and the cost per square foot of collector (row 3A). The costs per square foot of collector again represent advanced state-of-the-art systems and goals systems. However, they are not unrealistic given the projected time frames and expected improveinents. Row 9 lists the total capital costs for the four hypothesized systems.

Table 5-7 presents the average annual operating and maintenance (O\&N) costs. Although some costs are clearly based upon best estimates, row 6 shows that the total annual O\&M costs as percentages of the total initial system costs fall well within the commonly accepted range; the rule-of-thumb figure usually quoted is an average of approximately $2 \%$ of initial system costs for annual O\&M expenses.

are $50 \mathrm{MBtu} / \mathrm{hr} \div 198=252 ; 500 \mathrm{ft}^{2}$ and $50 \mathrm{MBtu} / \mathrm{hr} \div 240=208,300 \mathrm{ft}^{2}$, respectively.

2. Typical ground cover ratios for parabolic troughs and central receivers are 0.45 and 0.25 . Hence, the actual land coverage for System $B$ is $252,500 \div 0.45=561,100 \mathrm{ft}^{2}$ and for system D, $208,300 \div 0.25=833,200 \mathrm{ft}^{2}$.

3. At $43,560 \mathrm{ft}^{2} /$ acre, the land requirements for $50 \mathrm{MBtu} / \mathrm{hr}$ peak capacity solar EOR Systems B and D would equal approximately 13 and 19 acres, respectively.

Total land requirements for the baseline sizing standard adopted in this study are 17 acres and 30 acres for Systems $B$ and D, respectively. The peak-sized systems are $30-40 \%$ smaller, and the relative difference between land areas required by the central receivers versus parabolic troughs is slightly smaller (only $45 \%$ more area required for a central receiver as opposed to an earlier $75 \%$ ). System costs will obviously vary in proportion to collector field size, as will the annual energy delivered, but the relative comparison of the levelized energy costs is unchanged. 


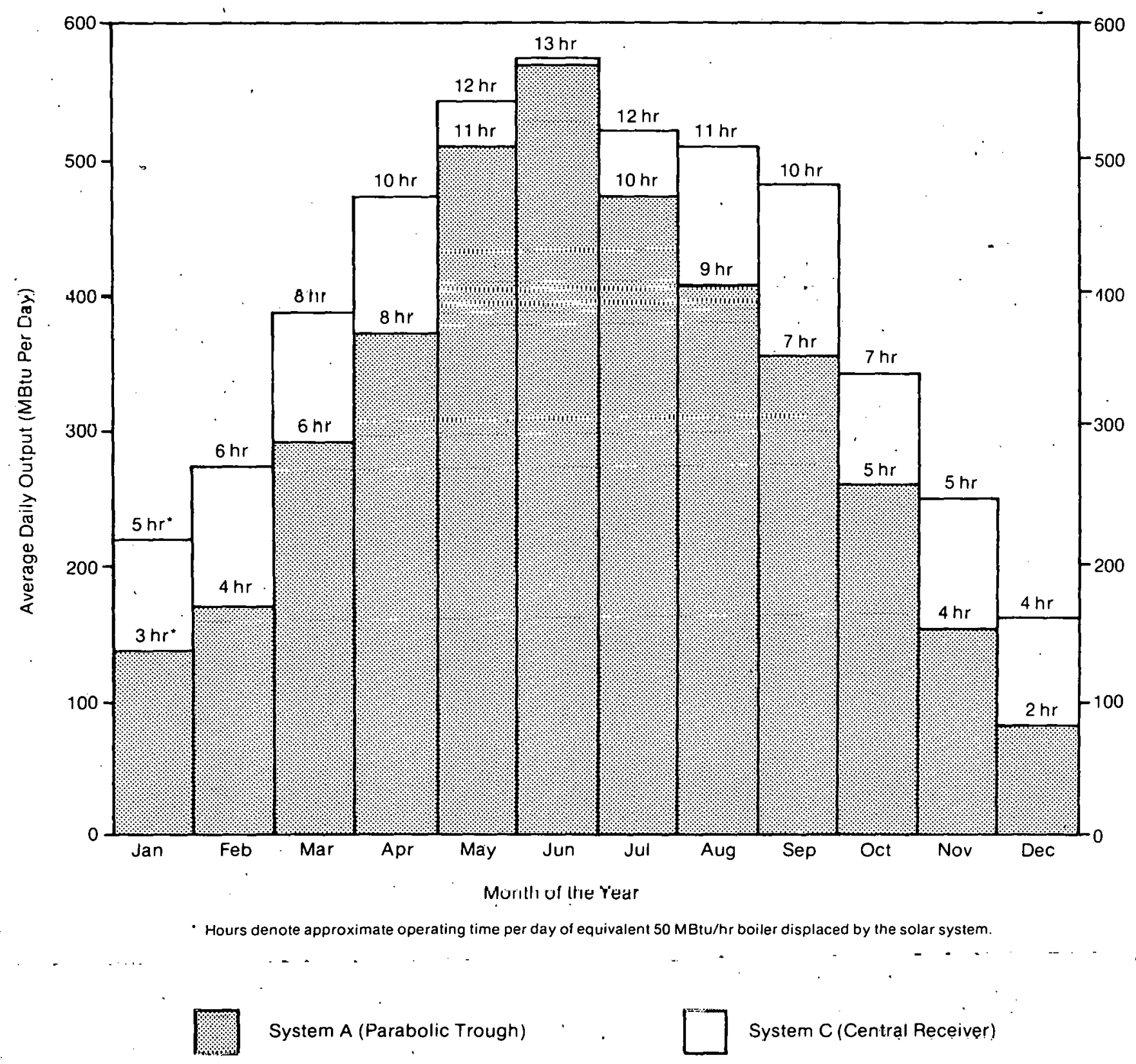

Figure 5-7. Monthly Energy Delivery from Solar Portlon of a Retrofit Hybrid EOR System ( $A$ and $C$ ) 
Tảle 5-6. COMPARATIVE SYSTEM CAPITAL COSTS

\begin{tabular}{|c|c|c|c|c|c|}
\hline \multirow[b]{2}{*}{ Item } & \multirow[b]{2}{*}{ Units } & \multicolumn{2}{|c|}{ Parabolic 'Trough System } & \multicolumn{2}{|c|}{ Central Receiver Systems } \\
\hline & & $\mathrm{A}$ & $B$ & $\mathrm{C}$ & $\mathrm{D}$ \\
\hline 1. Collector area & $\mathrm{ft}^{2}$ & 348,200 & 303,900 & 319,100 & 308,900 \\
\hline 2. Energy delivered & MBtu/yr & 112,800 & 115,800 & 132,200 & 135,000 \\
\hline $\begin{array}{l}\text { 3. Collector field } \\
\text { A) Unit cost }\end{array}$ & $\begin{array}{l}\$ 1,000 \\
\$ / \mathrm{ft}^{2}\end{array}$ & $\begin{array}{l}7,486 \\
21.50\end{array}$ & $\begin{array}{l}3,647 \\
12.00\end{array}$ & $\begin{array}{l}3,829 \\
12.00\end{array}$ & $\begin{array}{r}1,853 \\
6.00\end{array}$ \\
\hline 4. Receiver and tower & $\$ 1,000$ & - & - & 125 & 125 \\
\hline 5. Steam generator & $\$ 1,000$ & 125 & 125 & 125 & 125 \\
\hline 6. Other direct $\operatorname{costs}{ }^{a}$ & $\$ 1,000$ & 1,100 & 770 & 1,200 & 840 \\
\hline 7. Total Direct Costs & $\$ 1,000$ & 3,711 & 4,542 & 6,054 & 3,718 \\
\hline $\begin{array}{l}\text { A) Per unit area } \\
\text { B) Per unit capacity }\end{array}$ & $\begin{array}{l}\$ / \mathrm{ft}^{2} \\
\$ / \mathrm{MBtu} / \mathrm{yr}\end{array}$ & $\begin{array}{l}25.00 \\
77.23\end{array}$ & $\begin{array}{l}14.95 \\
38.89\end{array}$ & $\begin{array}{l}18.97 \\
45.79\end{array}$ & $\begin{array}{l}12.04 \\
27.54\end{array}$ \\
\hline 8. Indirect Cost & $\$ 1,000$ & 2,178 & 1,136 & 1,514 & 930 \\
\hline $\begin{array}{l}\text { 9. Total Cost } \\
\text { A) Per unit area } \\
\text { B) Per unit capacity }\end{array}$ & $\begin{array}{l}\$ 1,000 \\
\$ / \mathrm{ft}^{2} \\
\$ / \mathrm{MBtu} / \mathrm{yr}\end{array}$ & $\begin{array}{r}10,880 \\
31.27 \\
96.53\end{array}$ & $\begin{array}{l}5,678 \\
18.68 \\
48.61\end{array}$ & $\begin{array}{l}7,568 \\
23.72 \\
57.25\end{array}$ & $\begin{array}{l}4,648 \\
15.05 \\
34.43\end{array}$ \\
\hline
\end{tabular}

Notes: a Other direct costs include such items as land preparation and the installation of the master control systems. $\mathrm{b}_{\text {Indirect }}$ costs include contingency and overhead fees and are estimated at $25 \%$ total direct costs (row 7 ). 
Table 5-7. AVERAGE ANNUAL OPERATING COSTS

\begin{tabular}{|c|c|c|c|c|c|c|}
\hline \multirow[b]{2}{*}{ Item } & \multirow[b]{2}{*}{ Ūnits } & \multicolumn{2}{|c|}{ Parabolic Trough System } & & \multicolumn{2}{|c|}{ Central Receiver Systems } \\
\hline & & A & $\mathrm{B}$ & & $\mathrm{C}$ & $\mathrm{D}$ \\
\hline 1. Cleaning $\left(\$ 0.26 / \mathrm{ft}^{2} / \mathrm{yr}\right)^{\mathrm{a}}$ & $\$ 1,(100$ & 90.5 & 79.0 & ' & 83.0 & 80.3 \\
\hline 2. Routine maintenanee & $\$ 1,0,00$ & 77.5 & 38.0 & & 50.0 & 19.7 \\
\hline 3. Power-related costs ${ }^{c}$ & $\$ 1,, 000$ & 15 & 10 & & 10 & 7 \\
\hline 4. Operating personnel and overhead ${ }^{d}$ & $\mathrm{sl,c00}$ & 65 & 60 & & 65 & 60 \\
\hline 5. Total annual costs ${ }^{\mathrm{e}}$ & $\$ 1,000$ & 248 & 187 & & $\therefore 08$ & 167 \\
\hline $\begin{array}{l}\text { 6. As \% of initial system total } \\
\text { cost }\end{array}$ & & 2.3 & 3.3 & & 2.7 & 3.6 \\
\hline
\end{tabular}

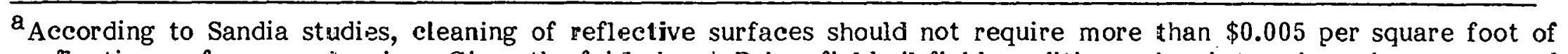
reflective surface per cleaning. Given the fairly harsh Bakersfield oil field conditions, cleaning each week was assumed by mechanized means.

${ }^{b}$ Routine maintenance was taken as $1 \%$ of colleetcr field installed cost per year.

CPower related costs are rough estimates.

$\mathrm{d}_{\text {Assumes one person full-time plus overheac. }}$

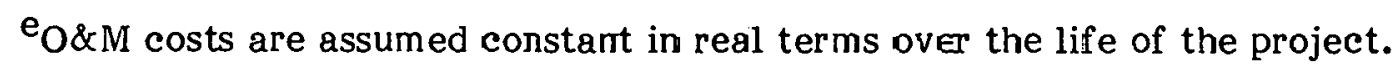


Table 5-8 shows the calculated levelized energy costs for the four systems. The levelized costs shown represent only the costs of the supplemental solar energy system. For the proposed solar retrofit hybrid system, a conventional steam generating system to which the solar EOR system would be connected is assumed to exist. The annualized or levelized costs are based upon the annual energy delivered (row 1 ; from Table 5-5, row 9), the total capital costs (row 2; from Table 5-6, row 9), and annual O\&M costs (row 3 ; from Table 5-7, row 5). The methodology for estimating annualized costs is described in detail in Doane et al. (1976) but can be summarized briefly by the following expression:

$$
\mathrm{X}_{1}(\mathrm{CAP})+\mathrm{X}_{2}(\mathrm{O \& M}) \text {, }
$$

in which $\mathrm{CAP}=$ the total capital costs and $\mathrm{O} \& \mathrm{M}=$ annual operating costs. The following parameters are used to calculate the two values of $X:$

$\begin{array}{ll}\text { Total return on investment } & \begin{array}{l}13.1 \% * \\ \text { Amortization period }\end{array} \\ \text { Tax life } & \begin{array}{l}20 \text { years } \\ 10 \text { years }\end{array} \\ \text { Investment tax credit } & 20 \% \\ \text { Income tax rate } \\ \quad \text { Federal } \quad 48 \% \\ \text { State } \quad 4 \% \\ \quad \text { Composite } \\ \text { Insurance } \quad 0.75 \% \text { CAP } \\ \text { Property tax } \quad 1.25 \% \text { CAP } \\ \text { Composite } \\ \text { Rate of inflation }\end{array}$

Straight line depreciation was used. The annualized costs are given in three units: the levelized costs per year (row 5); the levelized costs per unit energy (row 6); and the levelized costs per barrel of steam. Each of the three sets of costs is given in both "constant" dollars (rows 5A, 6A, and 7A) and "norninal" dollars (rows 5B, 6B, and 7B). Constant dollars are dollars whose purchasing power will remain constant throughout the life of the system, implying that their face value increases by a factor of 3.2 over the 20 -year amortization period because of inflation. The nominal dollar values are expressed in 1979 dollars and will decrease in their "real" value as inflation reduces their purchasing power.

Two important reservations must be recognized for Tables 5-5 through 5-8. First, the relative price differences between the central receiver and the parabolic trough systems are explained largely by their differences in net annual efficiencies and the unit costs of the collector subsystems. Both variables have large uncertainty bands. The respective net efficiencies could vary by as much as $10 \%$. For instance, the goals technology for parabolic troughs assumes major advances in both materials technology (e.g., reflectivities of 0.95 and glass transmissivity of 0.96 ) and in receiver vacuum tube technology. Evacuated receiver tubes reduce receiver thermal losses but also may significantly increase parasitic power requirements by an unknown amount. The history of cost estimations for advanced technologies consistently has revealed underestimates

*This return on investment was taken from the Atlantic Richfield Company (1978a, $1978 \mathrm{~b})$; this figure is approximately the average of the petroleum industry, as reported by the Chase Manhattan Bank, Energy Economics Division (1978). 
Table 5-8. LEVELIZED ENERGY COSTS

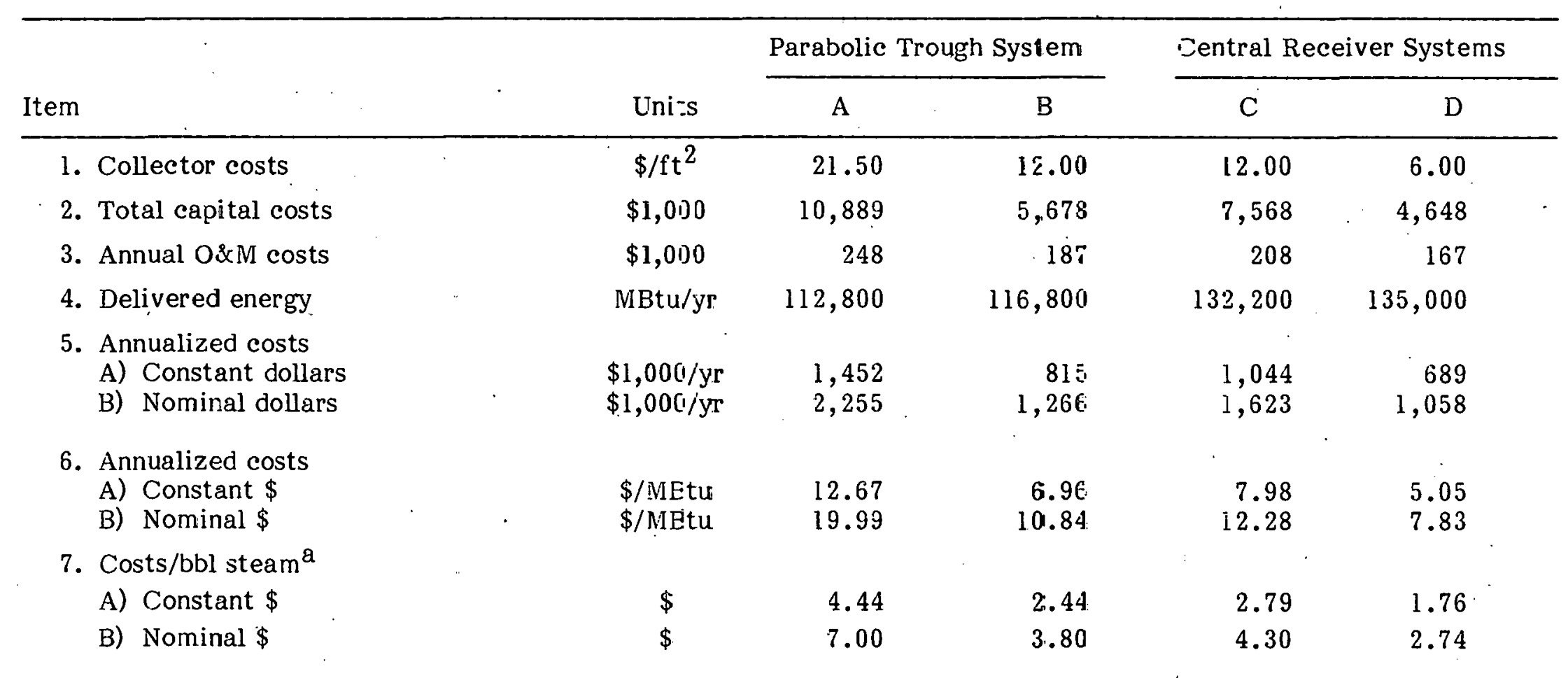

\footnotetext{
$\mathrm{a}_{\text {At }}$ the specific temperature and pressure (for this study, $545^{\circ} \mathrm{F}$ and $1000 \mathrm{psi}$ ), there are $350.154 \mathrm{lbs}$. water per barrel. This number, multiplied by the levelized energy costs (Rows $6 a$ or $6 b$ ) and divided by 100a, equals the cost per barrel of steam.
} 
by a factor of two to three,* and the current simulation program is admittedly optimistic. Changes in these values (e.g., materials technology) would significantly affect the annualized costs of solar EOR, especially relative to the conventional steam EOR systems whose performances and costs are well known (even given the escalation in fuel prices). In spite of the uncertainty about absolute efficiencies and costs of solar technologies, the relative magnitudes of these factors are typical of such systems (i.e., central receiver vs. parabolic troughs) as they evolve. Therefore, while the absolute value of the levelized costs may change, the ratio of the levelized costs between technologies should remain nearly constant. A second major reservation is that care must be taken in comparing time frames and technologies. These systems have been characterized as "advanced state-of-the-art" and "goals," with 4- to 5-year and 10- to 15-year time frames, respectively. Again, these are judgments incorporating substantial uncertainties. Breakthroughs in either technologies or processes could accelerate one technology's advantage at a given time. Still, on the average, these projections represent advances that can be expected within the specified time horizons.

Table 5-9 represents two hypothesized stand-alone solar EOR systems with no dedicated storage or conventional backup: the parabolic trough-system A-and central receiversystem C (i.e., the advanced state-of-the-art technology). These system estimates indicate the size and cost of a solar EOR system in which no conventional fossil-fired system is used. An important feature of the stand-alone system must be recognized. The systems are sized to deliver the same amount of energy as would a conventional system over the course of a year. However, due to the intermittent nature of solar energy, a solar EOR system cannot deliver steam throughout the 24-hr day. Therefore, the stand-alone system must compensate by delivering vast amounts of steam during the daylight hours. This is reflected in the projected peak thermal capacity of about 200$\mathrm{MBtu} / \mathrm{hr}$. As noted earlier, two of the critical uncertainties in designing steam drive EOR systems are the petroleum reservoir's response characteristics and the ability of the well casing to withstand greater steam injection rates and diurnal cycling. Peak thermal capacities of over four times the average rated capacity could present significant problems with respect to reservoir response and the well casings. Since these problems are unresolved, the stand-alone solar EOR system as defined here should be subject to serious technical reservation.

Continuous and controlled operation via solar stand-alone EOR systems might be obtainable through the use of dedicated storage. With in-series thermal storage, control is achieved by directing all of the collector field energy through and from storage at a controlled rate to fire the steam generator. Such systems would be more expensive than the stand-alone system (described in Table 5-9), which theoretically makes use of all the solar energy collected, minus transfer losses. In practice, however, the stand-alone, nonstorage system will waste collectible energy as a result of its inability to use very low output rates early and late in the day and of expected limitations on allowable peak output. Therefore, dedicated thermal storage should be investigated carefully for use in stand-alone solar EOR systems.

*Merrow et al. (1979) offer recent evidence to support this phenomenon. 
Table 5-9. STAND-ALONE SOLAR EOR SYSTEM

\begin{tabular}{|c|c|c|}
\hline & $\begin{array}{c}\text { System A } \\
\text { (Parabolic Trough) }\end{array}$ & $\begin{array}{c}\text { System C } \\
\text { (Central Receiver) }\end{array}$ \\
\hline $\begin{array}{l}\text { Annual energy delivered } \\
\text { Net annual delivered energy } \\
\text { Required collector area } \\
\text { Land area required } \\
\text { Peak thermal capacity } \\
\text { Total capital cost } \\
\text { Annual O\&M costs: } \\
\text { Annualized oostc } \\
\text { Levelized costs } \\
\text { Levelized cost/bbl steam }\end{array}$ & $\begin{array}{c}394,200 \mathrm{MBtu} \\
0.324 \mathrm{MBtu} / \mathrm{ft}^{2} \\
1,216,700 \mathrm{ft}^{2} \\
64 \text { acres } \\
196 \mathrm{MBtu} / \mathrm{hr} \\
\$ 38,050,000 \\
\$ 850,000 \\
\$ 5,058,500 \\
\$ 12.83 / \mathrm{MBtu} \\
\$ 4.49\end{array}$ & $\begin{array}{c}394,200 \mathrm{MBtu} \\
0.414 \mathrm{MBtu} / \mathrm{ft}^{2} \\
952,200 \mathrm{ft}^{2} \\
89 \text { acres } \\
221 \mathrm{MBtu} / \mathrm{hr} \\
\$ 2 \%, 590,000 \\
\$ 600,000 \\
\$ 3,097,000 \\
\$ 7.86 / \mathrm{MBtu} \\
\$ 2.75\end{array}$ \\
\hline
\end{tabular}

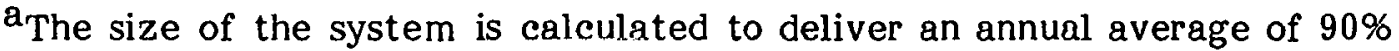
of full capacity $50-\mathrm{MBtu} / \mathrm{hr}$ steam generator, operating $8,760 \mathrm{hr} / \mathrm{yr}$, or to deliver $394,200 \mathrm{MBtu} / \mathrm{yr}$.

${ }^{b}$ All values given in constant dollars. The cost parameters defined in Table 5-8 apply here.

Where the displacement of one $50-\mathrm{MBtu} / \mathrm{hr}$ boiler is necessary and steam production rates in excess of $50-\mathrm{MBtu} / \mathrm{hr}$ are unacceptable, a very large field of solar collectors (infinite collector area) without storage can provide only a 45\%-50\% capacity factor. Obviously, adding collector area alone will not produce the required $90 \%$ capacity factor. Adding to the collector area by itself when the capacity factor is near $45 \%$ increases the capacity factor only slightly while significantly increasing the collector area and costs.

Figure 5-8 shows the effect of additional solar collector area and added storage on the annual capacity factor. With storage available, there is a critical collector field area (curve B) required to produce a $100 \%$ capacity factor. For collector areas in excess of the critical area, it is apparent from Fig. 5-8 that some 12 to 15 hours of storage will be required to obtain a $90 \%$ capacity factor. For field areas close to the critical value, very large amounts of storage (approximately 1000 hours) are required to obtain a $100 \%$ capacity factor. The collector field area calculated in Table 5-9 for the stand-alone system without storage is less than the critical field area for the solar EOR system with storage because losses certainly will be encountered in opcrating through sturage. If one assumes an average storage efficiency of about $80 \%$, approximately $25 \%$ more collector area will be required to reach the critical field area. For 15 hours of storage (see Fig. 58 , curve C), 1.46 times the critical area is required. Hence System A must have a collector area of

$$
(1.25)(1.46)\left(1,216,700 \mathrm{ft}^{2}\right)=2,220,500 \mathrm{ft}^{2},
$$

and System $\mathrm{C}$ must have a collector area of

$$
(1.25)(1.46)\left(952,200 \mathrm{ft}^{2}\right)=1,737,800 \mathrm{ft}^{2} \text {. }
$$

Table 5-10 shows the size and costs of a 50-MBtu/hr, 90\% capacity, solar stand-alone system with storage. 


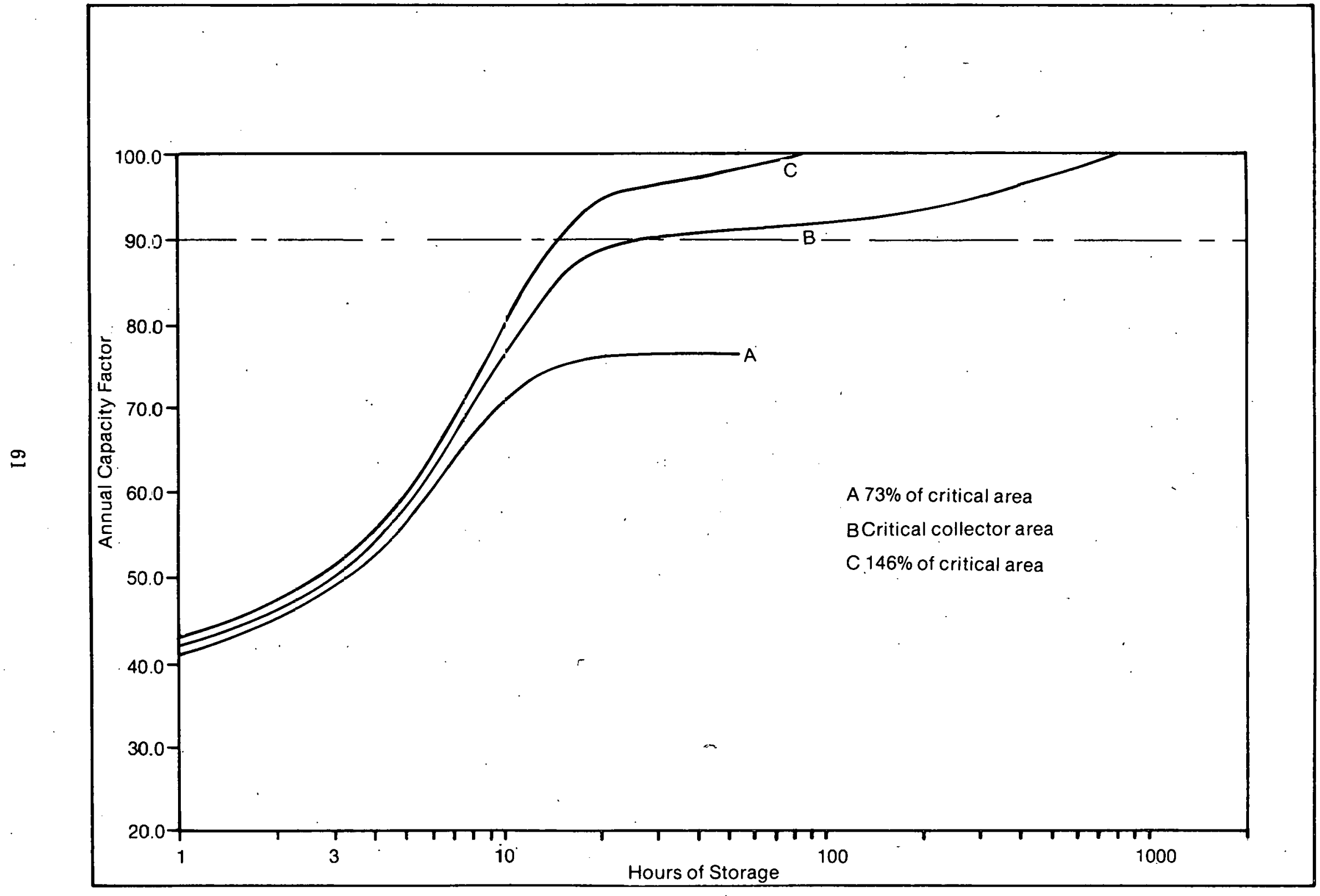

Figure 5-8. Annual Capacity Factor vs. Storage Size for Several Collector Areas (.lannucci 1978 , p. 213) 
Table 5-10. STAND-ALONE SOLAR EOR SYSTEM WITH STORAGE

\begin{tabular}{|c|c|c|}
\hline & Parabolic Trough System & Central Receiver System \\
\hline & System A & System C \\
\hline Required collector area $\left(\mathrm{ft}^{2}\right)$ & $2,220,500$ & $1,737,800$ \\
\hline Land area required (acres) & 115 & 161 \\
\hline Peak thermal capacity (MBtu/hr) & 50 & 50 \\
\hline Cost of collector subsystcm $(\$ 1000)$ & 47,741 & 20,854 \\
\hline Cost of storage subsystem ${ }^{a}(\$ 1000)$ & 3,441 & 1,025 \\
\hline Total capital cost $(\$ 1000)^{b}$ & 65,852 & 44,348 \\
\hline Annual O\&M costs $(\$ 1000)$ & 1,000 & 1,000 \\
\hline Annual energy delivered (MBtu/yr) & 394,200 & 394,200 \\
\hline Annualized costs $(\$ 1000 / y r)^{c}$ & 8,240 & 5,703 \\
\hline Levelized costs $(\$ / M B t u)^{c}$ & 21.00 & 14.74 \\
\hline Cost of steam $\left(\$ / b_{1} b_{1}\right)^{c}$ & 7.35 & 5.16 \\
\hline
\end{tabular}

$a_{\text {Storage costs assumed for System } \mathrm{A} \text { are } \$ 13 / \mathrm{kWh}}$ and $\$ 40 / \mathrm{kW}$ for latent heat storage; System $\mathrm{C}$ costs are $\$ 4 / \mathrm{kWh}$ for molten salt storage.

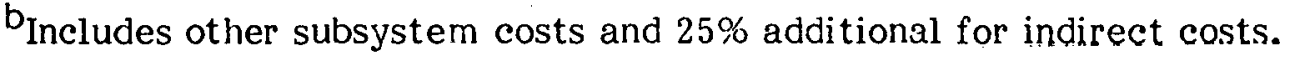

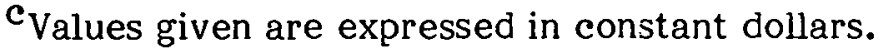

While storage may be necessary to the operation of a full-capacity, stand-alnne solar EOR system where heat must be regulated to a given level, the cost of such a system is substantially higher than those of currently acceptable conventional systems or future competitive solar EOR systems. The major contribution to these higher costs is the additional collector field necessary to charge the storage capacity rather than the storage subsystem iteclf.

As mentioned earlier in this section, standards for sizing solar thermal EOR systemsbased on peak capacity, peak daily output, or annual average output-have not been established. Although levelized annual energy costs provide a consistent basis of comparison and should, therefore, be emphasized, land availability is also important; that is, if the oil field operator has only a fixed amount. of suitable land available, which rolnr EOR technology is most suitable? Assume, for instance, that only 50 acres are available. Table 5-11 shows that the parabolic trough system will deliver more energy on a fixed acreage, despite its lower net annual efficiency, due to the larger assumed groundcover ratio. In terms of conversion efficiency on a total land area basis, System A offers approximately $19 \%$ and System C offers $14 \%$ conversion of available radiation. However, the capital cost of System C is only $42 \%$ that of System A so that if capital investment were more restricted than land, System $\mathrm{C}$ would be prefferred to System $\mathrm{A}$. In the illustration shown here, a limitation of $\$ 20$ million and 50 acres of land favors a central receiver system; if the capital restriction were relaxed, the parabolic trough system would be preferred. 
Table 5-11. COMPARISON OF SOLAR THERMAL EOR SYSTEMS (A AND C) FOR FIXED LAND AVAILABILITY

\begin{tabular}{|c|c|c|}
\hline & $\begin{array}{c}\text { PARABOLIC TROUGH } \\
\text { (System A) }\end{array}$ & $\begin{array}{c}\text { CENTRAL RECEIVEI } \\
\text { (System C) }\end{array}$ \\
\hline Land available (acres) & 50 & 50 \\
\hline Ground cover ratio & 0.45 & 0.25 \\
\hline $\begin{array}{l}\text { Available collector area } \\
\left(\mathrm{ft}^{2}\right)\end{array}$ & 980,100 & 544,500 \\
\hline Net annual system efficiency & 0.43 & 0.55 \\
\hline $\begin{array}{l}\text { Net annual efficiency } \\
\quad \text { (based on total land area) }\end{array}$ & 0.193 & 0.138 \\
\hline $\begin{array}{l}\text { Net annual energy delivered } \\
(\mathrm{MBtu} / \mathrm{yr})\end{array}$ & $3 i 7,347$ & 225,505 \\
\hline Total capital cost & $\$ 30,647,730$ & $\$ 12,915,540$ \\
\hline
\end{tabular}

Finally, Table 5-12 gives the levelized costs for a conventional; fossil-fired steam generating system that would be comparable to a full-capacity solar EOR system (Tables 5-9 and 5-10). In determining levelized costs for the conventional systems, the costing assumptions used for the solar systems were retained. Three levelized costs are calculated based on different prices of oil used to fire the steam generator; the middle column represents the prevailing price under President Carter's recent decontrol of heavy crude prices (Rattner 1979). The costs of full capacity, hybrid, solar-fossil EOR systems are given in Table 5-13; these include the capital and operating expenses of the fossil-fired backup system as well as the solar system. The levelized costs are appropriate for comparing investment decisions between a solar hybrid EOR system and conventional steam generation (using $\$ 12 / \mathrm{bbl}$ oil).

\subsection{PINDINGS}

A review of Tables 5-5 through 5-13 leads to three important findings, even in the face of the reservations expressed earlier in this section. First, central receivers appear to have a clear cost advantage for solar EOR. For the advanced state-of-the-art systems (A versus $C$ ), estimated levelized costs for the central receiver are $37 \%$ less than those for the parabolic trough; for the goals systems ( $B$ versus $D$ ), the difference, although reduced to $28 \%$, remains significant. These differences are explained largely by the respective systems' net efficiencies and collector costs, variables which are subject to admitted uncertainty. However, the cost differences between the two systems are significant and, if the uncertainties were resolved without a dominant bias for the parabolic troughs, one would expect the central receiver system to remain the more cost-effective solar technology.

This preference might be reinforced by the greater adaptability of central receiver systems to the rugged terrain that characterizes the California oil fields. In addition, for 
a fixed and limited capital investment and on limited available land, central receiver systems are much more cost effective despite the energy delivery advantages of parabolic troughs.

Table 5-12. CONVENTIONAL THERMAL EOR COSTS

\begin{tabular}{|c|c|c|c|}
\hline \multirow[b]{2}{*}{$\cdot$} & \multicolumn{3}{|c|}{ Selling Price/bbl Oil } \\
\hline & $\$ 7.00$ & $\$ 12.00$ & $\$ 22.00$ \\
\hline Total cost $(\$ 1,000)^{\mathrm{a}}$ & $1,000,000$ & $1,000,000$ & $1,000,000$ \\
\hline Ull cost $(\$ /$ bbl recovered) & 5.00 & 7.00 & 12.00 \\
\hline $\begin{array}{l}\text { Annual O\&M }(\$)^{\mathrm{b}} \\
4: 1 \text { steam:oil ratio }\end{array}$ & $1,400,000$ & $1,960,000$ & $3,360,000$ \\
\hline Delivered energy (MBtu/yr) & 420,000 & 420,000 & 420,000 \\
\hline Annual costs $(\$ 1,000)^{\mathrm{C}}$ & 1,458 & 2,013 & 3,413 \\
\hline Levelized cost $(\$ / M B t u)^{c}$ & 3.47 & 4.80 & 8.13 \\
\hline Cost/bbl steam $(\$)^{c}$ & 1.22 & 1.68 & 2.85 \\
\hline
\end{tabular}

Second, solar EOR systems are cost effective as compared to fossil-fired EOR systems only in the goals stage of system development, which has been defined as 10-15 years in the future. Comparing the goals (system D) central receiver costs for a levelized barrel of steam (in constant dollars) with the costs for a conventionally generatcd barrel of sleam (at $\$ 12.00 / \mathrm{bbl}$ oil cost) shows that the two costs are within $6 \%$ of each other. However; it should be stressed that the former costo include greater uncertuinties than the latter and, even more important, reflect a 10- to 15-year time horizon, with all the technology and cost improvements that projection implioity incorporates. Within the more immediate 4 to 5 -year time frame, the central receiver (system C) is almost $25 \%$ more expensive than the conventional oil-fired systems (again assuming $\$ 12 / \mathrm{bbl}$ ) on the basis of levelized energy costs.*

Third, while stand-alone solar EOR systems are at least as cost-effective as the corresponding solar-fossil hybrid systems, important technical questions remain as to adverse

*There are, of course, important uncertainties attached to the price of oil (even when expressed in constant dollars), as recent history richly documents, which could affect the comparative economics of the alternative thermal EOR systems. 
Table 5-13. SOLAR-FOSSIL HYBRID EOR COSTS

\begin{tabular}{lrrrr}
\hline & $\begin{array}{r}\text { Parabolic } \\
\text { A }\end{array}$ & Trough Systems & \multicolumn{2}{c}{$\begin{array}{c}\text { Central Receiver Systems } \\
\text { A }\end{array}$} \\
\hline $\begin{array}{l}\text { Solar portion capital costs } \\
\quad(\$ 1000)\end{array}$ & 10,889 & 5,678 & 7,568 & 4,648 \\
$\begin{array}{l}\text { Conventional portion } \\
\text { capital costs }(\$ 1000)\end{array}$ & 1,000 & 1,000 & 1,000 & 1,000 \\
Total capital costs $(\$ 1000)$ & 11,889 & 6,678 & 8,568 & 5,648 \\
Solar O\&M costs $(\$ 1000)^{\mathrm{a}}$ & 248 & 187 & 208 & 167 \\
Conventional O\&M costs $(\$ 1000)^{\mathrm{b}}$ & 1,431 & 1,415 & 1,343 & 1,330 \\
Total O\&M costs $(\$ 1000)$ & 1,679 & 1,602 & 1,551 & 1,497 \\
Delivered energy $(\mathrm{MBtu} / \mathrm{yr})$ & 420,000 & 420,000 & 420,000 & 420,000 \\
Annualized costs $(\$ 1000)^{\mathrm{c}}$ & 2,993 & 2,340 & 2,498 & 2,121 \\
Levelized costs $(\$ / \mathrm{MBtu})^{\mathrm{c}}$ & 7.13 & 5.57 & 5.95 & 5.05 \\
Cost of steam $(\$ / \mathrm{bbl})^{\mathrm{C}}$ & 2.50 & 1.95 & 2.08 & 1.79
\end{tabular}

${ }^{a}$ From Table 5-8, Rows 2 and 3.

${ }^{b}$ Calculated as the fraction of operating fuel costs not saved by the solar system delivering energy as given in Table 5-8; e.g., for System A, the solar EOR system provides 112,800 MBtu $\div 420,000$ MBtu, or approximately $27 \%$ of the annual energy. Hence, the O\&M costs of the conventional backup portion of the system are $(1-0.27) \times \$ 1,960,000$, or $\$ 1,430,800$ per year.

CValues are given in constant dollars. 
effects on well casings, steam distribution networks, and reservoir response due to very large peak-to-average steam output rates. 'These questions require resolution before the stand-alone alternatives can be chosen for solar EOR, although, with adequate storage capacities, diurnal variations would not be a problem. In addition, capital costs for stand-alone systems are extremely high, on the order of three tirnes the cost of a corresponding hybrid system. High capital costs have been a persistent obstacle to the commercialization of solar energy systems. There is no reason to assume that a standalone system with capital costs more than three times that of comparable hybrid systems would be readily accepted by the petroleum industry or the lending institutions. Finally, land requirements for the stand-alone system also are great, close to three times those for hybrid systems. There are serious reservations as to the ability of petroleum producers to allocate such large amounts of space, especially when there are less spaceintensive alternatives available. In sum, the potential improvements in delivered cnergy costs offered by system storage are minor in comparison with the difficulties inherent in such large solar systems. For the foreseeable future, the solar-fossil hybrid should be the . preferred solar EOR system configuration.

In summary, design calculations indicate that a solar energy system can be built to generate enough steam to operate a steam drive EOR operation and to replace as inuch as one-third of the steam-producing capacity currently provided by fossil-fueled boilers. Furthermore, it can be reasonably predicted that annual costs for solar EOR systems will ijecrease as collectoi: efficiencies and costs are reduced by inproved solar technologies and manufacturing processes. But in the near term-that is, within the next 5 years-it is not realistic to expect solar EOR systems to be cost coinpetitive with conventional fossil-fired steam generators, even if the latter are equipped with environmentally mandated $\mathrm{SO}_{2}$ serubbers and heavy crude oil is decontrolled.

The pertinent questions, then, are both technical and economic. Uil producers currentiy have technological options available that are well-tested, developed, and farniliar if environmental offset regulations do not eliminate certain options. Production of inghtemperature steam with solar energy, on the other hand, is just berrinning to be field tested. Futhermore, fieid tests to be constructed in the next lew years will have costs much greater than those of conventional, fossil-fired steam EOR. Thus a lesearch prograin in solar EOH is necessary to resolve these questions. 


\section{SECTION 6.0}

\section{FINANCING SOLAR ENHANCED OIL RECOVERY}

\subsection{INVESTMENT DECISIONS AND PROJECT ECONOMICS}

The determination of a project's economic viability-whether it be for enhanced oil recovery, energy production, mining, manufacturing, or virtually any commercial enterprise-generally is based upon $100 \%$ cash investment, that is, equity financing. The evaluation of a project's viability on any basis other than a cash investment has three advantages. First, using borrowed capital, or what is known as leveraged investment, may make a potentially marginal project look attractive. Debt financing can lower annual operating costs and produce a higher return on investment; less obviously, it can produce greater losses.

Second, the financing and economic conditions that might exist at the time the investment is made are unknowns at the time an investment is being evaluated. A project that is economically attractive under $100 \%$ equity will yield greater returns when it is leveraged, but the actual rate of return will depend upon the economic conditions prevailing at the time of the investment. To eliminate this uncertainty, firms usually evaluate projects on the assumption of complete equity financing.

To illustrate these two points, Table 6-1 demonstrates how debt financing can magnify gains or losses on an investment. Just as leveraging can work to a firm's advantage, it can also work to its disadvantage (Stermole 1974).

A third advantage to economic analysis based on equity financing is to demonstrate the viability of the project to lending institutions. The lender evaluates the risk and uncertainty associated with the project from a different point of view than the borrower. The lender's objective is to minimize risk and uncertainties, thus ensuring repayment from cash flows generated by the project. Lending institutions want assurances that new investments are financially remunerative, economically sound, and meet predetermined economic investment criteria. Given the risk and uncertainties, a minimum acceptable rate of return must be met, without leverage, to satisfy the lender. The minimum acceptable rate of return is higher for projects with greater risk and uncertainty (Gibbs and Sroka 1978).

The risk of any investment is measured by the probability that any of the financial, economic, technical, and environmental variables will change over the amortization period or project life. For example, if a project includes capital equipment with a well-documented performance history, e.g., steam generators, the technical risk is low. If a newer technology without sufficient field experience is used, the probability of achieving the forecast performance is lower. Uncertainties include market demand, price, escalation, inflation, performance, reliability, salvage value, operating costs, construction period, and project life. Historical data can help to determine the degree of risk for technologies with a proven track record; such evidence is unavailable for new, untested technologies. 
Table 6-1. FINANCIAL RETURNS UNDER VARYING DEBT/EQUITY RATIOS ${ }^{a}$

\begin{tabular}{lllllll}
\hline $\begin{array}{c}\text { Rate of return on total } \\
\text { assets before interest }\end{array}$ & $2 \%$ & $5 \%$ & $6 \%$ & $8 \%$ & $11 \%$ & $14 \%$ \\
$\begin{array}{c}\text { Earnings before interest } \\
\text { and taxes }\end{array}$ & 4 & 10 & 12 & 16 & 22 & 28 \\
\hline
\end{tabular}

Firm A Debt $=0$

Taxable income

Tax at 50\%.

Available to common stork

\begin{tabular}{llllll}
4 & 10 & 12 & 16 & 22 & 28 \\
$\frac{2}{2}$ & $\frac{5}{5}$ & $\frac{6}{6}$ & $\frac{8}{8}$ & $\frac{11}{11}$ & $\frac{14}{14}$ \\
\hline $1 \%$ & $2.5 \%$ & $3 \%$ & $4 \%$ & $5.5 \%$ & $7 \%$
\end{tabular}

Firm B Uebt $=50 \%$

Taxable income

Interest

Gross interest

Tax

Available to common stock

$4 \quad 10$

6.

(2)

(1)

$\frac{6}{4}$

(1)

$\frac{2}{2}$

12
$\frac{6}{6}$
$\frac{3}{3}$

16

28

Return on common stock

$-1 \%$

$2 \%$

$3 \%$

$5 \%$

$8 \%$

$11 \%$

Firm C Debt $=75 \%$

Taxable income

Interest

Gross inoome

Tax

Available to common stock

Return on common stock

$\begin{array}{lr}4 & 10 \\ \frac{9}{(5)} & \frac{9}{1} \\ \frac{(2.5)}{(2.5)} & \frac{.50}{.50} \\ -5 \% & 1 \%\end{array}$

12
$\frac{9}{3}$
$\frac{1.5}{1.5}$
396

16
$\frac{9}{7}$
$\frac{3.5}{3.5}$
$7 \%$

22
9
13

28

$\begin{array}{rrr}10 & 16 & 22 \\ \frac{5}{5} & \frac{8}{8} & \frac{11}{11}\end{array}$

${ }^{a_{S}}$ ource: Weston and Brigham (1972, p. 252).

The greater the amount of leverage, the lower the annualized costs. Table 6-2 shows how a 70-30 debt financing arrangement can lower the levelized costs by an average of over $35 \%$ for the four hypothesized solar EOR systems. However, leveraging can work against the costs in the same way it affects the rate of return (see Table 6-1). Leveraging can cause a marginal- or high-censt projert to appear to have n enmpetitive or lower cost. For this reason, annualized costs also should be evaluated on a $100 \%$ equity investment. Again, when a firm evaluates alternatives to determine the lowest-cost method of energy production, it will have no assurance of the future availability of financing or the prevailing terms.

Firms have alternative investment choices and generally prefer to evaluate them on a $100 \%$ equity investment. After the investment decision is reached and the more attractive projects are selected, the specific financing arrangements are chosen. Financing decisions are not based entirely on the criteria used for investment decisions. The decision to invest in a project involves such variables as market share, social factors (e.g., 
Table 6-2. SOLAR EOR SYSTEMS: EQUITY VS. DEBT FINANCING

\begin{tabular}{|c|c|c|c|c|c|c|}
\hline \multirow{2}{*}{\multicolumn{2}{|c|}{ Item }} & \multirow{3}{*}{$\frac{\text { Units }}{\$ / \mathrm{ft}^{2}}$} & \multicolumn{2}{|c|}{ Parabolic Trough System } & \multicolumn{2}{|c|}{ Central Receiver System } \\
\hline & & & $\mathrm{A}$ & $\bar{B}$ & $\mathrm{C}$ & \\
\hline 1. & Collector costs & & 21.50 & 12.00 & 12.00 & 6.00 \\
\hline 2. & Total capital costs & $\$ 1000$ & 10,889 & 5,670 & 7,568 & 4,648 \\
\hline 3. & Annual O\&M costs & $\$ 1000$ & 248 & 187 & 208 & 167 \\
\hline 4. & Delivered energy & MBtu/yr & 112,800 & 116,800 & 132,200 & 135,000 \\
\hline 5. & $\begin{array}{l}\text { Annualized costs } \\
\text { A. Equity financed } \\
\text { B. Debt financed } \\
\text { B }\end{array}$ & $\begin{array}{l}\$ 1000 / \mathrm{yr} \\
\$ 1000 / \mathrm{yr}\end{array}$ & $\begin{array}{r}1,452 \\
914\end{array}$ & $\begin{array}{l}815 \\
534\end{array}$ & $\begin{array}{r}1,044 \\
671\end{array}$ & $\begin{array}{l}689 \\
451\end{array}$ \\
\hline 6. & $\begin{array}{l}\text { Annualized costs } \\
\text { A. Equity financed } \\
\text { B. Debt financed }\end{array}$ & $\begin{array}{l}\text { \$/MBtu } \\
\$ / \text { MBtu }\end{array}$ & $\begin{array}{r}12.67 \\
8.10\end{array}$ & $\begin{array}{l}6.96 \\
4.57\end{array}$ & $\begin{array}{l}7.98 \\
5.07\end{array}$ & $\begin{array}{l}5.05 \\
3.34\end{array}$ \\
\hline & $\begin{array}{l}\text { Costs/bbl steam }{ }^{c} \\
\text { A. Equity finance d }{ }^{a} \\
\text { B. Debt financed }\end{array}$ & $\begin{array}{l}\$ \\
\$\end{array}$ & $\begin{array}{l}4.44 \\
2.84\end{array}$ & $\begin{array}{l}2.44 \\
1.60\end{array}$ & $\begin{array}{l}2.79 \\
1.78\end{array}$ & $\begin{array}{l}1.76 \\
1.17\end{array}$ \\
\hline
\end{tabular}

${ }^{9}$ Expressed in eonstant dollars; see rows 5A, 6A, 7 A, Table 5-8.

b Expressed in constant dollars; calculated on a 70-30 debt to equity ratio.

${ }^{c_{S}}$ See footnote a, Table 5-8, for explanation of bbl of steam. 
community receptivity), political factors (e.g., government regulations), profitability, cash flows, payback, and risks. After these criteria have been satisfied according to the firm's objectives, the most suitable form of available financing will be arranged.

\subsubsection{Debt Financing}

The decision to utilize debt financing depends on the availability, form, and cost of the debt. By using debt financing, a firm lowers its operating costs but increases its financial risk; that is, there are important "hidden costs" to debt financing. These can affect the firm's bond rating, credit rating, available interest rates, earnings on common stock, and other important economic indicators of the firm's financial condition. The firm's financial position may be jeopardized as increasingly more debt is used to finance investments. The financial risk is increajed if the economic conditiuns do not remaln as predicted over the life of the investment. Leveraging may be employed to boost stockholder returns, but; as noted, it is done at the risk of increasing losses if the firm's economic fortunes decline (Weston and Brigham 1972, p. 267). Thus, debt financing can be viewed as a mixed blessing.

A firm's financial position and therefore the availability and cost of capital depend on such factors as the growth rate of future sales, stability of future sales, competitive structure of the industry, asset structure of the firm, control position and attitudes toward risk of owners and management, and lenders' attitudes toward the firm and the industry, some of which are clearly beyond the firm's influence (Weston and Brigham 1972 , p. 264). The cost of capital to the firm reflects the factors influencing its financial condition. It will be higher for a firm which has a high degree of leverage and investments of uncertain return.

The cost of capital is a deciding factor in a decision to use debt financing. If the return on the investment is greater than the cost of the debt, then debt financing is an attractive option. The cost of capital also reflects the degree of risk and the opportunity costs of the investment. If the borrowing or lending institutions have other investment opportunities that have lower risk and equal or lower rates of return, the cost of capital will be higher. The cost of capital thus manifests the riskiness of the investment and the exogenous supply and demand for capital. Higher risk investments demand higher costs of capital. Due to the greater technical risks associated with solar EOR in comparison with other thermal EOK processes or other energy investments, the solar EOR investor would pay a higher cost for capital than would an investor for a more conventional, less risky investment.

\subsubsection{Project Yinancing}

Project financing, either recourse or nonrecourse, may be an alternative way to finance.a technology commercialization project without affecting a firm's financial structure. Using project financing, a firm can invest without directly affecting its credit rating. For this reason, project financing has been proposed as an attractive option available for firms wishing to finance solar EOR.*

*For example, see Dollard (1979). 
Peter Nevitt defines project financing as the "financing of a particular economic unit in which a lender is satisfied to look initially to the cash flows as the source of funds from which a loan will be repaid and to the assets of the economic unit as collateral for the loan" (Nevitt 1978, p. 1). A project financed using these criteria, therefore, must demonstrate its ability to repay the debt from cash it generates. The assets associated with the particular project must also be of sufficient magnitude to act as collateral. The collateral acts as an equity share for the borrower and reduces the assumed risk for the lending institution. The size and the transferability of the collateral depend on the probability of project success and the uncertainties associated with it. Collateral for project financing may be in the form of assets associated with the project, firm, or a third party. Whatever the source of collateral, the attendant risk must be reduced to the lender's satisfaction.

The key to successful project financing is that it be structured with as little recourse as possible to the sponsor while providing sufficient credit support through guarantees or undertakings of the sponsor or a third party so that lenders are satisfied with the credit risk. Specific financial conditions must be met if a project is to be financed by this means. A viable project financing arrangement should present a strong credit backing, a credit-not an equity-risk, sufficient cash flow potential to repay the loan, a market for the product, strong management, and the appropriate political environment (e.g., the absence of restrictive government regulations). Nevitt points out that project financing generally is not suitable for new technologies because of the uncertain reliability of the process and the equipment to be used. The technical reliability and commercial viability of the project must be clear so as to satisfy a lender of the level of risk and the probability of repayment. For a new technology, lending risk is increased (Nevitt 1978, pp. 3-4).

Solar EOR at present, does not satisfy the three project financing criteria outlined by Nevitt. First, the current fungibility or transferability of the physical assets of a solar EOR facility is open to question, so that the equipment might not serve as adequate collateral to secure the loan. Second, the requisite cash flow for solar EOR has not been demonstrated. Third, the technology necessary to operate a commercial solar EOR facility has yet to be proven. All three criteria weigh against project financing as a means to commercialize solar EOR systems. If solar EOR could demonstrate greater financial certainty and commercial viability, this assessment probably would become more favorable.

\subsubsection{Leasing}

Leasing is another form of debt financing often posed as an alternative to the purchase of capital equipment. The economic criteria for leasing equipment are the same as for purchase. Whichever alternative proves to be economically more attractive from the standpoint of higher net present value and rate of return normally will be chosen. The decision to lcasc also is based on equipment sriteria such as reliability, system life, obsolescence, and salvage value. Regardless of the possible advantages of leasing for petroleum producers using solar EOR, the leasing company would be responsible for the capital investment. Any company investing in solar EOR technology for leasing purposes would face the same investment decisions as would a buyer (Stermole 1974). Financing under such a situation would be evaluated by the economic and financial criteria that confront a petroleum producer, with the additional constraint of needing an assuied customer for the equipment because the leasing company could not use the equipment itself. 
Leasing may provide an advantage by increasing the overall availability of nonequity financing to the firm. However, a leasing contract is very similar to a straight debt obligation and relies upon the firm's debt-carrying ability (Weston and Brigham 1972, p. 469). Leasing has advantages, especially when salvage value is expected to be small or is uncertain. It is especially attractive when the prevailing economics and technology will render the equipment obsolete in a relatively short time. For these reasons, the leasing of solar EOR systems or the purchase of steam for solar EOR may be more attractive to a petroleum producer than purchasing the system. However, it does not alleviate the need for primary financing by an investor.

\subsection{CONCLUSIONS}

In summary, there are many alternative means for financing capital investment projects in today's capital market. They vary primarily in the degree of risk they impose upon both the borrowing and lending institutions. Not surprisingly, there is no single best financing alternative for every investment. The preferred option for financing a specific new technology development will depend upon the state of the technology, the projected financial soundness of the investment (generally measured by the rate of return), and the prevailing economic conditions. To control for these and other uncertainties, projects are best evaluated assuming $100 \%$ equity financing. When the investment is actually made, the most suitable and available financing alternative will be chosen cooperatively by the borrower and the lender, based on the project's economic and technical feasibility, costs, management team, market demand, and opportunity costs for the money.

Solar EOR could be financed under any of the alternatives discussed in the preceding section. However, given the present economic uncertainties and the lack of technical proof-in-operation for commercial-size solar facilities, the availability of project financing for a solar EOR facility must be seriously questioned. Financial institutions might require government subsidies or a guaranteed loan program before lending large amounts of money to build a solar installation. Thus, equity financing or government support pro grams appear to be the most likely financial options for building a solar EOR facility within the near future, at least until the economic (see Sec. 3.0), institutional (see Sec. 4.0), and technical (Sec. 5.0) questions can be answered with greater confidence. 


\section{SECTION 7.0}

\section{CONCLUSIONS AND RECOMMENDATIONS}

A number of conclusions can be drawn from the preceding analysis that have distinct policy implications. These conclusions and recommendations can be grouped into three categories: the technology of solar EOR; the economics of solar EOR; and the institutional questions involving EOR.

\subsection{SOLAR EOR TECHNOLOGY}

Significant technical uncertainties surround both solar technologies and enhanced oil recovery; they must be resolved before any solar EOR concept will be commercially acceptable. By the end of 1980, approximately 75,000 square feet of parabolic trough collectors will have been installed for generating low and intermediate temperature steam for industrial processes. At the present time, the single commercial installation for the generation of low temperature steam has been in operation for only one year. No attempt has been made to generate relatively high-pressure steam using the kind of distributed parabolic trough system that would be required by a solar EOR facility. The only known commercial production of steam using central receiver technology is in Odeillo, France, where a solar test facility generated steam for producing electric power for about a year. Steam has been produced successfully in tests at the Central Receiver Test Facility in Albuquerque and the Georgia Institute of Technology Engineering Experiment Station in Atlanta, but on a limited basis for intermittent periods. No data will be available from large-scale commercial applications of central receiver steam generating systems until after the completion of the Barstow facility in the early 1980s.

In light of this lack of experience with large-scale operating solar steam systems, it is clear that solar thermal systems for generating high-pressure steam are subject to considerable technical uncertainty in the immediate future. The degree of design, testing, and reliability that is required for any commercial venture is not yet available for the proposed solar EOR technologies and applications. To assume that systems of nearly $300,000 \mathrm{sq} \mathrm{ft}$ of collector aperture area at existing technology levels are ready for commercial implementation is an assumption that simply has not been demonstrated. Further research, testing, and pilot-scale field tests are warranted, even necessary. For instance, recent evidence from six operating DOE field tests for industrial process heat shows that actual annual net operating efficiencies fell far below the goals (a maximum recorded efficiency of only $20 \%$ on design predictions of $40 \%$ ) and that considerably more engineering and research work is required before solar IPH systems can be considered technically and economically viable, even at low temperatures (Kutscher and Davenport 1979). In short, no commercial-sized system should be installed until the operation of smaller scale test systems, at the requisite steam conditions, is shown to be technically feasible.

In addition to concerns for the technical performance of solar technology for EOR, many crucial questions remain regarding the response of oil reservoirs to intermittent or variable solar steam injection. It is essential for the further design and construction of solar EOR equipment that such questions be accurately posed and answered by trained petroleum engineers operating in a controlled test environment. If, for example, reservoir recovery rates are not significantly affected by diurnal steam injection, the development of solar EOR can be accelerated. 
In summary, concerted research efforts in both solar technology and petroleum engineering are required before solar EOR can be implemented on a commercial scale. Questions as to the technical uncertainties were raised repeatedly by petroleum officials interviewed for this project. There is important research value to investigating both of these issues for long-term application of solar technology to EOR. Little, if any, value would be obtained by premature entry of a still-developing technology into an uncertain market. For these reasons, we strongly recommend the planning of controlled pilot projects to examine the technical uncertainties identified here and that operating experience with solar steam generating capacities be demonstrated before commercial-scale solar EOR applications are considered.

Central receiver systems are better suited to EOR applications than distributed parabolic trough systems. In certain federal demonstration programs a great deal of emphasis has been placed on the utilization of distributed parabolic trough systems for solar EOR, probably because of the more advanced state of technology and greater operating experience with parabolic troughs as compared to central receiver systems. Actual commercial experience with both systems is severely limited. This analysis argues that the prospects for the commercial adoption of solar EOR within the next five years is at best problematic. Neither technology presently offers costs or technical guarantees that would encourage commercial users to invest in these systems within that time frame. However, the analysis does suggest that, at equal performance levels and over the longer term, central receiver technology has a distinct cost advantage over the parabolic trough technology.

Several factors explain this finding. First, for the steam conditions used in this analysis ( 1000 psi, $80 \%$ quality), the average receiver operating temperature is approximately $560^{\circ} \mathrm{F}$. This operating temperature is at the extreme end of the reasonable operating limits of the parabolic trough, and at this temperature heat losses in the receiver and the transmission lines are substantial. On the other hand, a temperature of $560^{\circ} \mathrm{F}$ is easily within the operating range of central receiver equipment. It can, of course, be argued that selecting more conservative steam conditions (e.g., 600 psi) would improve the relative position of parabolic trough systems with respect to central receivers. Still, recent evidence suggests that central receivers may remain the favored technology even to temperatures in the $350^{\circ} \mathrm{F}$ range (Zoschak et al. 1979). By using a system comparison based on peak efficiency on a day in June, the analysis was partially biased towards the parabolic trough, yet the economics of the central receiver were still better than those of the line collector. Finally, in comparing the two system types based on annual energy delivered for a fixed price and investment dollar, the central receiver had a $70 \%$ advantage despite the greater energy delivery of parabolic systems.

Another factor contributing to the relative advantage of the central receiver is its flexibility in siting collectors on rough, uneven terrain. It may be possible to locate heliostats on very rugged landscape-albeit at higher costs-because no thermal transport piping is necessary. Parabolic troughs are probably limited to relatively flat sites because of their plumbing requirements.

Finally, several assumptions concerning future costs tend to make the central receiver even more advantageous. The analysis is predicated on the assumption that prospective cost reductions for heliostats and central receivers are considerable, an assumption substantiated by SERI's recent analysis of DOE's solar thermal repowering projects (Doane et al. 1979). While cost reductions through improved manufacturing processes also are foreseen for parabolic trough systems, the current best estimate is that the ultimate costs of distributed parabolic trough systems will exceed the ultimate costs of central receivers by approximately $15 \%$. 
For these reasons, we recommend that the DOE solar EOR program not restrict its acceptable technology choices to line collectors. Specifically, central receivers should be considered as possible candidates for EOR applications.

\subsection{SOLAR EOR ECONOMICS}

At the present time and for the near future, the application of solar technology to EOR is not a cost-effective option. One of this study's more important findings for immediate policy consideration concerns the comparative economics of solar and conventional thermal EOR systems. Although solar technology applications to EOR operations are forecast to be economically feasible, this condition does not exist in the near (i.e., 3-4 year) future. (This explicitly assumes that existing technologies for scrubbing oil-fired burner emissions continue to meet ambient air quality standards.) At prevailing oil prices $(\$ 12 / \mathrm{bbl}$ produced oil), the annualized cost of an oil-fired burner to produce a barrel of steam is $\$ 1.68$ (constant FY79 dollars). Assuming that technical difficulties with existing solar equipment can be overcome within the next five years, the cost of a barrel of steam produced by a parabolic trough solar EOR system is close to 1.5 times greater; the estimated cost of steam generated by a central receiver solar EOR. system is almost 1.25 times greater.

The central receiver EOR system-which presently has greater technical uncertainties than the parabolic trough-becomes price competitive with oil-fired systems only as its stated technology goals become realized, assuming that its costs stay within the assumed inflation parameter. Again, the predicted advances in solar. technologies and cost reductions probably bias these projections on the optimistic side. In addition, these costs probably do not completely reflect the costs of land preparation in the Kern River and Santa Barbara oil fields. In brief, while the research horizons might appear to make solar EOR a technically attractive and price competitive option, it is by no means guaranteed, and in any case it is a longer term (10-year) alternative. In the immediate time horizon, conventional fossil-fired thermal EOR systems are more reliable and economic.

It should also be appreciated that solar EOR will not be greatly advantaged by an increase in the cost of oil. While such an increase could make EOR more financially attractive to petroleum producers, it will not uniquely benefit solar EOR. All forms of EOR will benefit from increased oil prices, including some of the mole exotic chemical (e.g., polymer drive) and $\mathrm{CO}_{2}$ injection systems. Given higher oil prices, petroleum companies could invest in scrubbers or other nonsolar techniques to increase their EOR production rates. Thus, a government program to motivate solar technology applications to EOR by decontrolling oil prices could act against solar EOR and, in any case, would not be specifically beneficial. For this reason, we recommend that if the DOE wishes to emphasize solar techniques for enhanced oil recovery, the decontrol of oil prices might not be an adequate stimulus. Petroleum industry representatives stressed that the best way to interest the oil producing industry in solar EOR is to drive down the price of the solar equipment rather than to let the price of oil rise. Thus, specific development programs for solar energy technology applications to EOR appear to be the most effective way of encouraging industry adoption.

The market potential for solar EOR has not yet been determined; it represents still another critical uncertainty surrounding the future commercialization of solar EOR. One area not addressed directly by this study is the market potential for solar EOR were it found to be price competitive with conventional thermal EOR systems. There is ample evidence that factors other than cost influence a firm's decision to make major capital investments. These factors and standard economic analyses should be explored to 
determine the commercial potential of solar EOR systems. For example, the DOE might compile a land inventory of the California oil fields to determine whether there is enough space for a number of solar EOR systems. Without adequate land in the oil fields, the successful commercialization of solar EOR would be seriously constrained. Market penetration estimates should be calculated for solar EOR. In addition to projecting the overall effect of solar EOR on oil production, these estimates would indicate the effect of this particular application of solar technology upon the solar industry (e.g., its growth and financial condition).

This report has focused on the California market, the site of most of the nation's current thermal EOR activities. This attention was due to the characteristics of the California oil fields and the amount of available insolation. This emphasis is not meant to restrict the possible locations of solar EOR. Petroleum from the Texas oil fields is characteristically lighter than its California counterpart. There is some evidence that a greater percentage of the original oil in place can be extracted from a reservoir of "sweeter" crude (up to $85 \%$ in laboratory tests). Therefore, it would be worthwhile to explore the possibility of solar EOR use in the Texas and Louisiana oil fields, taking into account the local oil viscosity, reservoir characteristics, and insolation rates.

Project financing currently does not appear to be a viable way of funding solar EOR activities through the private market. As noted in the body of the report, project financing has been advanced as a way of developing solar EOR activities through the private sector. An examination of the project financing literature suggests that its availability depends on three main criteria: the guarantee of sufficient cash flow to repay the debt incurred; the perception of the assets that would serve as collateral should liquidation of the project be necessary; and, in the case of capital equipment purchases, the assurance that the technology's performance and rcliability are welldemonstrated. In terms of solar EOR, the first criterion is still a matter for serious speculation. The second criterion has yet to be demonstrated; there are no comparable steam-generating uses for which a solar EOR steam generator could be used, nor would a solar EOR facility be easy to relocate. Third, this analysis argues that solar EOR technology, at its present state of development, does not meet the last criterion.

In short, project financing does not appear to be a means for commercializing solar EOR projects at this time. When its uncertainties are reduced, it might be more applicable. In the interim, we recommend that other forms of financial arrangements, such as government-guaranteed loans, would be more useful in encouraging lending institutions to support solar EOR projects.

\subsection{LEGAL AND INSTITUTIONAL ISSUES REGARDING SOLAR EOR}

Air quality standards are not a motivating factor favoring solar EOR at the present time but could, in future years, become such a factor. Air permits for new oil-fired steam generators are presently available, assuming that the operator is willing to pay the cost of complying with the emission limitations and offset requirements. Thus, the air quality motivation for developing solar EOR systems does not seem compelling at this time. However, the availability of emission offsets in nonattainment areas may become increasingly constrained in future years as existing polluting facilities are shut down or 
retrofit with LAER control technologies.* In the future, emission offsets derived from LAER control technologies may not be available in nonattainment areas. For SIPs being drafted today, no air permits can be granted if emission offsets cannot be obtained. If offsets were not available, the benefits from solar systems could be significant because no fossil-fired systems-even those with LAER technology-could be constructed.

If emission offsets using LAER control technologies on old polluting facilities were no longer available in nonattainment areas, the air permit applicant would have three options. First, the applying company could resign itself to the fact that the region in which it wants to construct a stationary source is for all intents and purposes a "no growth" area until the NAAQS are attained and simply withdraw its application. Second, the applicant could apply for relief through the political process (e.g., the regulatory commissions or the relaxation of environmental standards). Finally, the applicant could obtain further emission offsets by using a control technology that is not generally considered to fall into the domain of conventional LAER control technologies. An obvious example of one such technology would be a non-polluting solar EOR system. Thus, in the eventuality that LAER technologies cannot provide additional emission of fsets, the air quality motivation for using solar thermal EOR systems may yet become a driving factor in their adoption.

Under the assumption that the air quality motivation for using solar EOR systems may be important in future years, it is recommended that research efforts be directed towards developing a solar EOR stand-alone capability. If a solar EOR system is to be a solution to the air quality problem, the system should be designed to operate without a fossil-fuel backup system for cloudy day and nighttime operations, since such backup systems would most likely be subject to the full range of emission limitations and of fset requirements. Thus, further work is needed in solar energy storage and in the design of nonpolluting backup systems if solar EOR systems are to be used to meet ambient air quality standards.

The petroleum industry is seriously interested in advances in solar EOR technology and costs but has little concrete information upon which to act. This observation was made repeatedly in SERI's interviews with petroleum officials. Many had "heard" of solar EOR but few had any hard information upon which to base company research or investment policies-one reason, perhaps, that the petroleum producing industry has not been enthusiastic about solar EOR development.

Petroleum industry officials also indicated that changing government regulations made long-term research and development policies difficult to formulate and to implement; that is, how could they convince corporate executives of the effectiveness of an investment in solar EOR when the solar credit might no longer be in effect by the time the system was operational? The mutability of government regulation of oil prices was another of ten-cited example of the long-term instability of government policy. This problem cannot be addressed by a simple policy recommendation, especially in a pluralistic political environment in which government policies must and do change as conditions

invironmental and air quality standards already are being clted as serious obstacles to -he increased heavy oil production encouraged by the Administration's decontrol of heavy crude and the proposed exemption of heavy crude from the windfall profits tax (Wilson 1979; Anonymous 19\% ya; Lancaster 1979). 
change. However, it is recommended that the DOE initiate an ongoing program to keep petroleum officials fully abreast of emerging technologies, either through the fossil fuel sections of the Department or by the relevant technology section.

Although there are many options for implementing government incentives to promote solar EOR, tax treatments are preferred by the petroleum industry. Favorable tax treatments such as investment tax credits, accelerated depreciation, and amortization are preferred by the oil industry over government loan guarantees, grants, demonstration projects, and incremental pricing mechanisms. Petroleum producers interviewed preferred not to have the public sector involved in their daily operations. Tax treatments can be used by the petroleum industry without the release of possibly proprietary information. They are reported only once per year and do not require the extensive review and reporting that of ten accompany other forms of incentive. Favorable tax treatments of ten involve lower administrative costs to a produccr than tax writeoffs. 'I'herefore, favorable tax treatments of high capital investments, along with price decontrols, were preferred by the industry over other forms of incentive.

If the DOE wishes to encourage private industry participation in the development of solar EOR, a tax incentive program would probably be the most effective method. It is certainly the petroleum industry's favored option. If solar EOR equipment is developed on schedule and performs as designed, a loan guarantee program would be the lowest cost option for the government because there might well be no cases of loan default. 


\section{SECTION 8.0}

\section{REFERENCES}

Ali, S.M. Farouq. 1970. Oil Recovery by Steam Injection. Bradford, PA: Producers Publishing Co.

Ali, S.M. Farouq. 1974. "Steam Injection." Second and Tertiary Oil Recovery Processes. Oklahoma City: Interstate Oil Compact Commission; p. 127.

Anonymous. 1977. "Survey of 65 Steam EOR Projects." Oil and Gas Journal. Vol. 75 (No. 12): 27 March 1977; p. 114.

Anonymous. 1978a. "Enhanced-Recovery Spending Keyed to Oil Price." Oil and Gas Journal. Vol. 76 (No. 17): 24 April 1978; p. 65.

Anonymous. 1978b. "U.S. Enhanced Recovery Marked by Uncertainties." Oil and Gas Journal. Vol. 76 (No. 37): 11 September 1978; pp. 35-41.

Anonymous. 1978c. More U.S. Crude to the Eligible for Free-Market Prices." Oil and Gas Journal. Vol. 76 (No. 31): 31 July 1978; p. 96.

Anonymous. 1979a. "Carter Orders Decontrol of Heavy Ćrude." Oil and Gas Journal. Vol. 77 (No. 35): 27 August 1979; pp. 38-39.

Anonymous. 1979b. "DOE Readies Incentives for Enhanced Oil." Energy Daily. Vol. 7 (No. 25): 5 February 1979; p. 1.

Anonymous. 1979c. "ERA Inhanced Recovery Incentives Sweetened." Oil and Gas Journal. Vol. 77 (No. 14): 2 April 1979; p. 62.

Anonymous. 1979d. "Shell Gets First Enhanced Recovery Price Relief." Oil and Gas Jnurnal. Vol. 77 (No. 17): 23 April 1979; p. 25.

Anonymous. 1979e. "ERA Moves to Boost Enhanced Recovery." Oil and Gas Journal. Vol. 77 (No. 35). 27 August 1979; p. 38.

Anonymous. 1979f. "Getty Shuts down Kern River Generators." Oil and Gas Journal. Vol. 77 (No. 4): 22 January 1979; p. 45.

Anonymous. 1979g. "DOE Pricing Policies Keep Kern River Generators Shut down." Oil and Gas Journal. Vol. 77 (No. 13): 26 March 1979; p. 53.

Atlantic Richfield Co. 1978a. Annual Report 1977. Los Angeles, CA: Atlantic Richfield Co.

Atlantic Richfield Co. 1978b. Supplement to the Annual Report 1977. Los Angeles, CA: Atlantic Richfield Co.

Berdahl, Paul et al. 1977. California Solar Data Manual. San Mateo, CA: Solar Energy Information Services. 
Bergeron, Kenneth D. 1979. Solar Enhanced Oil Recovery: An Assessment of Economic Feasibility. Report 79-0787. Albuquerque, NM: Sandia Laboratories.

California Air Resources Board. 1979. State Implementation Plan Revision, Kern County. Staff Report 79-6-4. Sacramento, CA: Calif. Air Resources Board.

California Division of Oil and Gas. 1976. Leased Land for Oilfield and Gas Development. Publication No. PR09. Sacramento, CA: Calif. Div. of Oil and Gas; 17 June 1976.

California Division of Oil and Gas. 1977. 62nd Annual Report of the State Oil and Lias Supcrvisor, 1970. Sacramento, CA: Calif. Div. of Oil and Gas,

Chaoc Manhattun Bunk, Energy Econnmirss Div. 1078. Finumulal Analysis of a Group of Petroleum Companies. New York: Chase Manhattan Bank.

Congressional Research Service. 1976. Energy Accounting as a Policy Analysis Tool. Washington, D.C.: U.S. House of Representatives Subcommittee on Energy Research, Development, and Demonstration.

Corrigan, Richard. 1979. "The Shaky, Unpredictable World of Energy Investment." National Journal. Vol. 11 (No. 16): 21 April 1979; pp. 646-650.

Craig, F.F. Jr. 1978. "Waterflooding." Secondary and Tertiary Oil Recovery Processes. Oklahoma City: Interstate Oil Compact Commission; p. 22. -

deIseon, Peter; MeNown, Robert. 1979. Potential Effects on the U.S. Economy and Society Resulting from a Dependence on Foreign Petroleum Sources and Possible Solar Energy Response. SERI/TR-51-070. Golden, CO: Solar Energy Research Institute.

Dollard, Jim. 1979. "Memorandum: Solar Financing." Wushingtón, U.C.: U.S. Dept. of Energy; '24 Apriil 1979.

Doane, James W. et al. 1976. The Cost of Energy from Utility-Owned Solar Electric Systems. JPL-5040-29. Pasadena, CA: Jet Propulsion Laboratory.

Doune, James W. et al. 1979. A Government Role in Solar Thermal Repowering. SERI/TR-51-340. Golden, CO: Solar Energy Research Institute.

Environmental Protection $\Lambda$ gency. 1978. "National Ambient Air Quality Standards, State's Attainment Stat.ıs." Federnl Registur. Vol. 43 (No. 43): 23 March 1978, p. 8983.

Environmental Protection Agency. 1979a. "Emission Offset Interpretive Ruling." Federal Register. Vol. 44 (No. 11): 1979; p. 3280.

Environmental Protection Agency. 1979b. Federal Register. Vol. 44 (No. 173): 5 September 1979; pp. 51924-51959.

Farahan, E. 1977. Central Heating: Package Boilers. ANL/CES/TE 77-6. Oak Ridge, TN: Oak Ridge National Laboratory.

Gibbs, Norman J.; Sroka, John. 1978. "What Bankers Look for in Project Loan Applications." Mining Engineering. Vol. 30 (No. 12): December 1978; pp. 1646-1648. 
Goldman Sachs Research. 1976. Prospects for Production of Heavy Oil Reserves. Los Angeles, CA: Goldman Sachs Research.

Gray, Morris G. 1975. "A New Appraisal of the Rights of Lessees under Oil and Gas Leases to Use and Occupy the Surface." Rocky Mountain Mineral Law Institute. Vol. 20: 1975; pp. 227-282.

Gulf Universities Research Consortium. 1973. Planning Criteria Relative to a National RDT\&D Program to the Enhanced Recovery of Crude Oil and Natural Gas. Report No. 130. Galveston, TX: Gulf Universities Research Consortium.

Gulf Universities Research Consortium. 1976. Preliminary Field Test Recommendations and Prospective Crude Oil Fields or Reservoirs for High Priority Testing. Report No. 148. Galveston, TX: Gulf Universities Research Consortium.

Henwood, Mark. 1977. Thermal Enhanced Oil Production in California: Coal's Potential Role. Sacramento, CA: California Energy Commission.

Henwood, Mark. 1978. Feasibility and Economics of Cogeneration in California's Thermal Enhanced Oil Recovery Operations. Sacramento, CA: California Energy Commission.

Iannacci, J. J. 1978. Thermal Storage Applications Workshop.' Pasadena, CA: Jet Propulsion Laboratory, JPL Document No. 5102-78, Vol. II.

ICF, Inc. 1979. Capital Resources and Requirements for Petroleum Industry under the National Energy Plan. Washington, D.C.: ICF, Inc.

Interstate Oil Compact Commission. 1974. Secondary and Tertiary Oil Recovery Processes. Oklahoma City: Interstate Oil Compact Commission.

Kern County Air Pollution Control District. 1979. Permit to Operate: Getty Oil Company. Bakersfield, CA: Kern County Air Pollution Control District.

Kutscher, C.; Davenport, R. 1979. Performance Results and Experiences of the Operational IPH Field Tests. SERI/TR-34-385. Golden, CO: Solar Energy Research Institute.

Lancaster, Hal. 1979. "Hopes for Using More 'Heavy Oil' Fade As Air Quality Controls Deter Producers." Wall Street Journal. 24 October 1979; p. 48.

Lewin and Associates. 1976a. Research and Development in Enhanced Oil Recovery. Washington, D.C.: Lewin and Associates.

Lewin and Associates. 1976b. The Potential and Economics of Enhanced Oil Recovery. Washington, D.C.: Lewin and Associates for the Federal Energy Administration.

Maize, Ken. 1979. "Financial Wizards Cool Synfuels Fever." The Energy Daily. Vol. 7 (No. 140): 24 July 1979; p. 1.

Manı, C.E.; Heller, J.N. 1978. Coal and Profitability: An Invcstor'E Guide. New York: Coøl Week/McGraw-Hill. 
Mathematica Inc. 1975. The Estimated Recovery Potential of Conventional Source Domestic Crude Oil. Princeton, NJ: Mathematica.

Merrow, Edward W.; Chapel, Stephen W.; Worthing, James C. 1979. A Review of Cost Estimation in New Technologies: Implications of Energy Process Plants. R-2481DOE. Santa Monica, CA: The Rand Corp.

McCann, Patrick; White, Jay D.; Adolfson, William F. 1979. Solar Steam Generation for Enhanced Oil Recovery. Bethesda, MD: Booz, Allen, \& Hamilton.

Meyers, Richard. 1979. "DOE Cuts R\&D on Oil Recovery." Energy Daily. Vol. 7 (No. 18): 25 January 1979; p. 1.

National Petroleum Council. 1970. Enllanced Oll Recovery. Washington, D.C.: National Petroleum Council.

National Science Foundation. 1974. Final Task Force Report: Solar Encrgy: Project Independence. Washington, D.C.: Government Printing Office.

Nevitt, Peter K. 1978. Project Financing. New York: Advanced Management Research.

Noran, Dave. 1978. "Growth Marks Enhanced Oil Recovery." Oil and Gas Journal. Vol. 76 (No. 12): 27 March 1978; p. 114.

Office of Technology Assessment. 1978. Enhanced Oil Recovery Potential in the United States. Washington; D.C.: U.S. Government Printing Office.

Oil and Gas.Journal. 1965. $2 \dot{3}$ August 1965.

Parisi, Anthony J. 1979. "Hope for Heavy-Oil Producers." New York Times. 19 .Tuly 1979 ; pp. $\mathrm{D}=1, \mathrm{~L}-5$.

Rattner, Steven. 1979. "President Decontrols Price of Heavy Crude." New York Times. 18 August 1979; p. 27.

Schumacher, M.M., ed. 197̄8. Enhanced Oil Recovery: Secondary and Tertiary Methods. Park Ridge, NJ: Noyes Data Corporation.

Shells, Merrill. 1979. "Pumping Oil thc Hard Way." Newsweek. 30 April 1979; pp. 61-62.

Simpson, J.I. 1977. "Financing Enluneed Recovery." Journal ol Pelroleum Technology. Vol. 29: July 1977; pp. 771-775.

Solomon, Burt. 1979a. "Carter Lists Control on Heavy Oil." Energy Daily. Vol. 7 (No. 161): 22 August 1979; pp. 1-2.

Solomon, Burt. 1979b. "Steam Goes out of Getty's Kern River Field. Energy Daily. Vol. 7 (No. 53): 20 March 1979; pp. 1-2.

Stermole, Franklin. 1974. Economic Evaluation and Investment Decision Methods. Golden, CO: Investment Evaluation Corp. 
Stobaugh, Robert; Yergin, Daniel, eds. 1979. Energy Future. New York: Random House.

Tanner, James C. 1976. "Strapped for Capital, Major Oil Firms Sell Interests in Production to Get Financing." Wall Street Journal. 26 January 1976; p. 24.

Thornton, John P. et al. 1979. Comparative Ranking of 1-10 MW $\mathrm{e}$ Solar Thermal Electric Power Systems: An Executive Summary. SERI/TR-35-238. Golden, CO: Solar Energy Research Institute.

Weston, J. Fred; Brigham, Eugene F. 1972. Managerial Finance. Hinsdale, IL: Dryden Press.

Wheeler, Robert R.; Whited, Maurice. 1975. Oil from Prospect to Pipeline. Houston, TX; Gulf Publishing Co.

Wilson, Howard M. 1979. "Heavy Crude Decontrol Sparks Mixed Emotions." Oil and Gas Journal. Vol. 77 (No. 36): 3 September 1979; pp. 29-32.

Zaschak, F. J.; Sommerlad, R. E.; Rogan, J. E. 1979. Central Receiver Solar Energy Systems for an Oil Refinery. 1979 Solar Industrial Process Heat Conference; Oakland, CA: October 1979. 


\section{SEPI}


Appendix A: Table A-1. AMBIENT AIR QUALITY STANDARDS

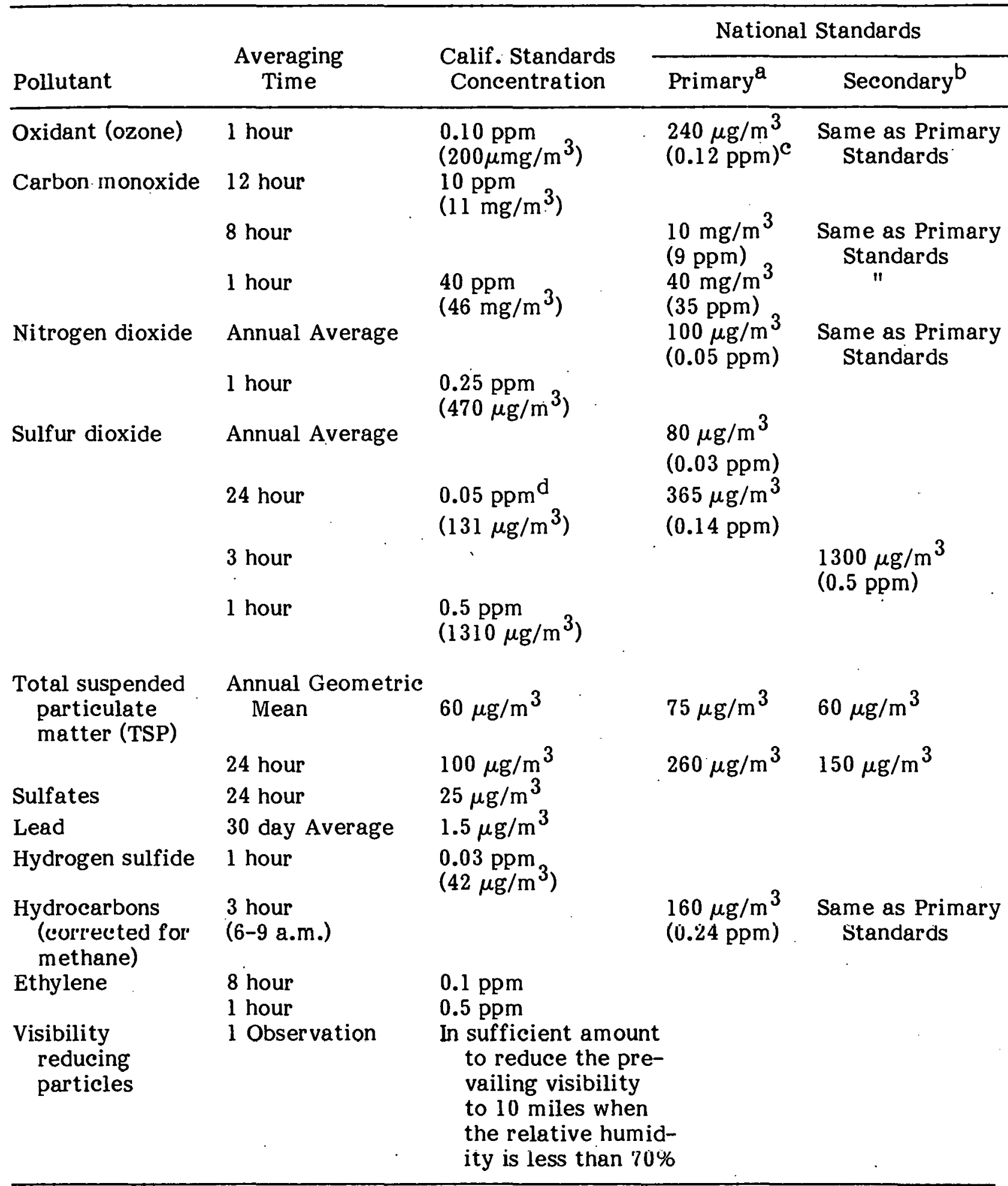

Source: California Air Resources Board and the United States Code of Federal Regulations.

${ }^{\text {a }}$ Designed to protect health.

${ }^{b}$ Designed to enhance visibility and aesthetics.

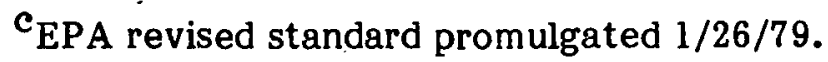

$\mathrm{d}_{\text {With }}$ simultaneous violation of the state 1-hr oxidant standard or state 24-hr TSP standard. 


\section{SE리*}

A-2 


\section{Appendix B}

\section{POTENTIAL $\mathrm{SO}_{2}$ EMISSIONS FROM A 50-MILLION BTU/HR BOILER}

Assume:

1. The $\mathrm{SO}_{2}$ emission factor equals $157 \mathrm{~S}$ pounds of $\mathrm{SO}_{2}$ emitted per thousand gallons of fuel oil burned, where $S$ equals the percentage sulfur in the fuel oil by weight (Office of Technology Assessment 1978, p. 95).

2. One barrel equals 42 gallons.

3. One barrel fuel oil equals 6.2 million Btu.

4. Fuel oil sulfur content for a typical Kern County EOR operation is $1.1 \%$ (Kern County 1979). This implies that $S=1.1$.

Thus,

$\frac{50 \times 10^{6} \mathrm{Btu}}{\mathrm{l} \mathrm{hr}} \times \frac{1 \text { barrel oil }}{6.2 \times 10^{6} \mathrm{Btu}} \times \frac{42 \mathrm{gal}}{1 \text { Barrel }} \times \frac{24 \mathrm{hr}}{1 \text { day }} \times$

$\frac{157(1.1) \mathrm{lb} \mathrm{SO}_{2}}{1000 \text { gal oil }} \times \frac{36 \grave{5} \text { days }}{1 \text { year }} \times \frac{1 \text { ton }}{2000 \mathrm{lb}}=\frac{256 \text { tons } \mathrm{SO}_{2}}{1 \text { year }}$

These are the uncontrolled $\mathrm{SO}_{2}$ emissions from a $50-\mathrm{MBtu} / \mathrm{hr}$ oil boiler using $1.1 \%$ sulfur oil.

If the scrubber eliminates $96 \%$ of the emissions, then:

$(0.04) \times 256$ tons $\mathrm{SO}_{2}$

1 year

This figure is called the "potential emissions" for the $50-M B t u / h r$ oil burner. 
SEPI

B-2 


\begin{tabular}{|c|c|c|c|}
\hline $\begin{array}{l}\text { Document Control } \\
\text { Page }\end{array}$ & $\begin{array}{l}\text { 1. SERI Report No. } \\
\text { SERI /TR-352-392 }\end{array}$ & 2. NTIS Accession No. & 3. Recipient's Accession No. \\
\hline \multicolumn{3}{|c|}{ Solar Technology Application to Enhanced nil Recovery } & $\begin{array}{l}\text { 5. Publication Date } \\
\text { December } 1979\end{array}$ \\
\hline & & & 6. \\
\hline $\begin{array}{l}\text { 7. Author(s) } \\
\text { Peter deleon, Ke }\end{array}$ & oneth $C$. Brown, Jame & W. Margolis, Louise & 8. Pertorming Organization Rept. No. \\
\hline \multirow{2}{*}{\multicolumn{3}{|c|}{$\begin{array}{l}\text { 9.. Performing Organization Name and Address } \\
\text { Solar Energy Research Institute/DOE } \\
1617 \text { Cole Boulevard } \\
\text { Golden, Colorado } 804.01\end{array}$}} & $\begin{array}{c}\text { 10. Project/Task/Work Unit No. } \\
\text { Task } \$ 5631.98\end{array}$ \\
\hline & & & $\begin{array}{l}\text { 11. Contract (C) or Grant (G) No. } \\
\text { (C) } \\
\text { (G) }\end{array}$ \\
\hline \multirow{3}{*}{\multicolumn{3}{|c|}{ 12. Sponsoring Organization Name and Address }} & 13. Type of Report \& Period Covered \\
\hline & & & Technical Report \\
\hline & & & 14. \\
\hline
\end{tabular}

15. Supplementary Notes

16. Abstract (Limit: 200 words) One proposed near-term commercial application for solar energy technology is the use of solar energy systems to generate steam for thermal enhanced oil recovery (EOR). This report examines four aspects of solar energy employed for steam EOR. First, six solar technologies are evaluated and two--parabolic troughs and central receivers--are selected for closer study; typical systems that would meet current production requirements are proposed and costed. Second, the legal and environmental issues attending solar EOR are analyzed. Third, the petroleum producing companies' preferences and requirements are discussed. Finally, alternative means of financing solar EOR are addressed. The study concludes that within the next four to five years, conventional (fossil-fueled) thermal EOR means are much less expensive and more available than solar EOR systems, even given environmental requirements. Within 10-15 years, assuming specified advances in solar technologies, central receiver EOR systems will be significantly more cost-effective than parabolic trough EOR systems and will be price competitive with conventional thermal EOR systems. Important uncertainties remain (both in solar energy technologies and in how they affect the operating characteristics of petroleum reservoirs) that need resolution before definitive projections can be made.

17. Document Analysis mental Aspects; Legal Aspects; Financing; Financial Incentives; Leases; Surface Rights; Water Rights; Water Pollution Control: Air Quality; Clean Air Act; Standards;

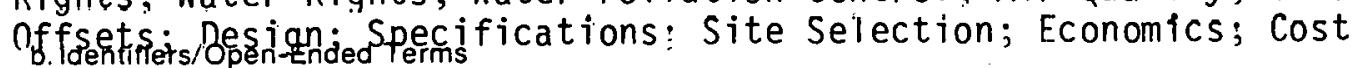

c. UC Categories $59 \mathrm{~b}$

18. Availability Statement
NTIS, U.S. Nept. of Commerce

5285 Port Royal Road

Springfield, VA 22161

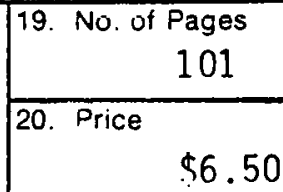

